\title{
EFEITO DE ALGUNS PARÂMETROS OPERACIONAIS NAS CARACTERÍSTICAS FÍSICAS, FÍSICO-QUÍMICAS E FUNCIONAIS DE EXTRUSADOS DA FARINHA DE BATATA-DOCE (Ipomoea batatas)
}

\author{
ALEXANDRA MORELI BORBA
}

Dissertação apresentada à Escola Superior de Agricultura "Luiz de Queiroz", Universidade de São Paulo, para obtenção do título de Mestre em Ciências, Área de Concentração: Ciência e Tecnologia de Alimentos.

P I R A C I C A B A

Estado de São Paulo - Brasil

Julho -2005 


\title{
EFEITO DE ALGUNS PARÂMETROS OPERACIONAIS NAS CARACTERÍSTICAS FÍSICAS, FÍSICO-QUÍMICAS E FUNCIONAIS DE EXTRUSADOS DA FARINHA DE BATATA-DOCE (Ipomoea batatas)
}

\author{
ALEXANDRA MORELI BORBA \\ Licenciada em Ciências Biológicas \\ Orientadora: Prof ${ }^{\mathrm{a} .} \mathrm{Dr}^{\mathrm{a}}$. SILENE BRUDER SILVEIRA SARMENTO \\ Dissertação apresentada à Escola Superior de
Agricultura "Luiz de Queiroz", Universidade de São
Paulo, para obtenção do título de Mestre em Ciências,
Área de Concentração: Ciência e Tecnologia de
Alimentos.
}

P I R A C I C A B A

Estado de São Paulo - Brasil

Julho -2005 
Dados Internacionais de Catalogação na Publicação (CIP) DIVISÃO DE BIBLIOTECA E DOCUMENTAÇÃO - ESALQ/USP

Borba, Alexandra Moreli

Efeito de alguns parâmetros operacionais nas características físicas, físico-químicas e funcionais de extrusados da farinha de batata-doce / Alexandra Moreli Borba. - -

Piracicaba, 2005.

98 p. : il

Dissertação (Mestrado) - - Escola Superior de Agricultura Luiz de Queiroz, 2005. Bibliografia.

1. Amido 2. Batata-doce 3. Extrusão 4. Farinha - Análise físico-química

5. Processamento de alimento 6 . Viscosidade I. Título

CDD 664.80522

"Permitida a cópia total ou parcial deste documento, desde que citada a fonte - $\mathrm{O}$ autor" 


\section{DEDICATÓRIA}

A Deus pelo dom da vida e por todo o Seu Amor, que tem guiado meu coração.

Ao meu marido e companheiro Jorge, pelo amor e apoio em todos os momentos da minha vida.

À minha mãe Simone, por todo seu amor e carinho e ao meu pai José Carlos.

À minhas irmãs Adriana, Amabile e Aline, pelas alegrias vividas e por darem minhas sobrinhas Beatriz, Melissa, Gabriele e Maria Vitória.

Ao meu irmão Augusto, por ser o presente de Deus em minha vida.

A toda minha família, pelo carinho que enriquece a minha vida. 


\section{AGRADECIMENTOS}

À Prof ${ }^{\mathrm{a}} \operatorname{Dr}^{\mathrm{a}}$ Silene Bruder Silveira Sarmento, pela orientação e amizade, que me auxiliaram no crescimento profissional.

À pesquisadora $\operatorname{Dr}^{\mathrm{a}}$ Magali Leonel, do CERAT/UNESP, pelo incentivo e por sua participação na execução deste trabalho.

Ao CERAT/UNESP, pela disponibilização das instalações para a realização da parte de extrusão deste trabalho.

À FAPESP, pelo auxílio financeiro ao projeto através do processo n ${ }^{0}$ 03-05135-0.

Ao professor Dr. Marcelo Correa Alves, do CIAGRI/ESALQ/USP, pelo auxílio na análise estatística do trabalho.

À técnica Carlota Boralli Prudente dos Anjos, do Laboratório de Amido e Féculas, do LAN/ESALQ/USP, pelo auxílio nas análises deste projeto, por sua amizade e carinho.

Ao Manoel Divino da Matta Júnior, Luciana C. Brigatto Fontes, Savianne C. M. Iensen e Ana Carolina Leme, do Laboratório de Amidos e Féculas, do LAN/ESALQ/USP, pelo auxílio nas análises deste trabalho, além da amizade e carinho.

Ao Laboratório de Processamento de Frutas e Hortaliças, do LAN/ESALQ/USP, pelo empréstimo dos equipamentos para a realização das análises.

À $\operatorname{prof}^{\mathrm{a}} \operatorname{Dr}^{\mathrm{a}}$ Solange G. C. Brazaca e a técnica Maria de Lourdes do LAN/ESALQ/USP, pela liofilização da farinha utilizada na avaliação do grau de gelatinização.

Ao desenhista projetista Luiz Carlos Rodrigues, do LAN/ESALQ/USP, pelo auxílio na parte gráfica. 
Á $\operatorname{prof}^{\mathrm{a}} \operatorname{Dr}^{\mathrm{a}}$ Célia M. L. Franco, do Depto. de Engenharia e Tecnologia de Alimentos/IBILCE/UNESP, pelas sugestões ao trabalho por ocasião do exame de qualificação.

À bibliotecária Beatriz H. Giongo, do LAN/ESALQ/USP, pelo auxílio na correção bibliográfica deste trabalho.

A todo o pessoal de Departamento de Agroindústria, Alimentos e Nutrição, da ESALQ/USP, que contribuíram com a realização deste projeto.

Ao LAN/ESALQ/USP, pela disponibilização das instalações para a realização deste trabalho. 


\section{SUMÁRIO}

Página

LISTA DE FIGURAS ............................................................................. ix

LISTA DE TABELAS .............................................................................

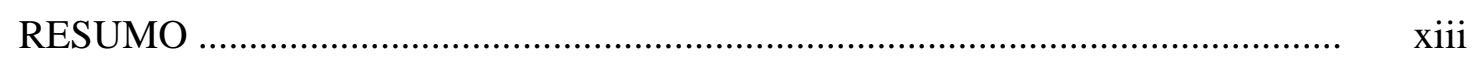

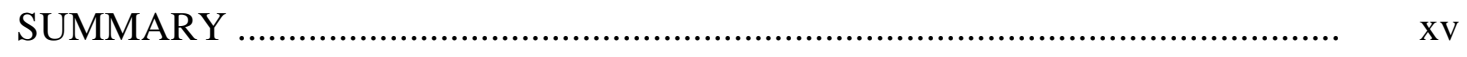

1 INTRODUÇÃO ........................................................................................ 1

2 REVISÃO DE LITERATURA ................................................................. 3

2.1 A cultura da batata-doce ............................................................................... 3

2.1.1 Composição química da raiz de batata-doce .................................................. 4

2.1.2 Utilização comercial e tecnologia de processamento da batata-doce ............ 5

2.2 A extrusão ................................................................................................ 7

2.2.1 O processo de extrusão ........................................................................... $\quad 10$

2.2.2 Vantagens e aplicações da extrusão .............................................................. 11

2.2.3 Impacto do processo sobre o valor nutricional dos extrusados ......................... 13

2.2.4 Fatores que interferem na qualidade dos produtos extrusados ..................... 14

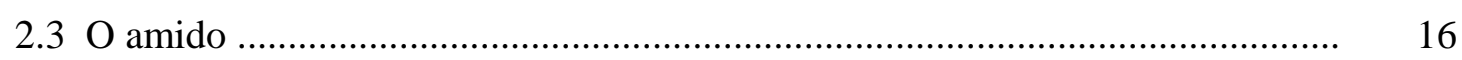

2.3.1 Influência dos componentes do amido e as interações moleculares do amido durante o processo de extrusão .................................................................. 17

2.3.2 Modificações químicas e físicas do amido extrusado ................................... 19

2.3.3 Algumas propriedades funcionais e físico-químicas do amido extrusado ..... 22

3 MATERIAL E MÉTODOS …....................................................................... 30

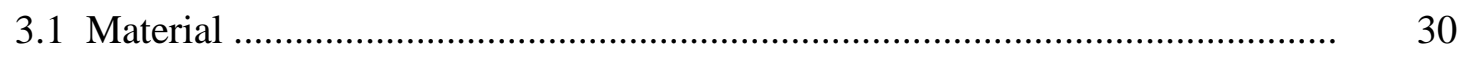


3.1.1 Matéria-prima ....................................................................................... $\quad 30$

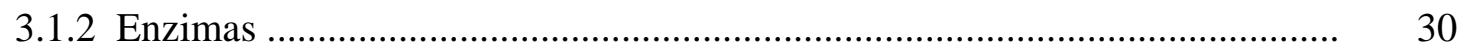

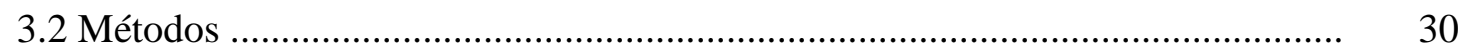

3.2.1 Produção de farinha de batata-doce ............................................................. $\quad 30$

3.2.2 O processo de extrusão ............................................................................... 32

3.2.3 Obtenção da farinha de batata-doce extrusada ............................................. 33

3.2.4 Caracterização das farinhas de batata-doce .................................................... 33

3.2.4.1 Microscopia eletrônica de varredura (MEV) ............................................... 34

3.2.4.2 Composição físico-química .......................................................................... 34

3.2.4.2.1 Umidade ................................................................................................. 34

3.2.4.2.2 Proteína bruta ...................................................................................... 34

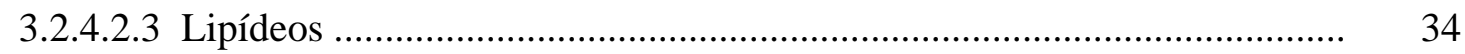

3.2.4.2.4 Cinzas ............................................................................................... 34

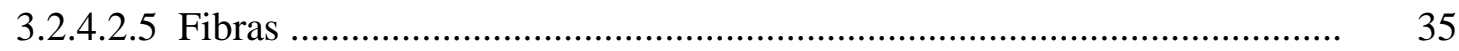

3.2.4.2.6 Amido .................................................................................................. $\quad 35$

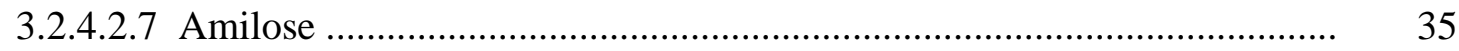

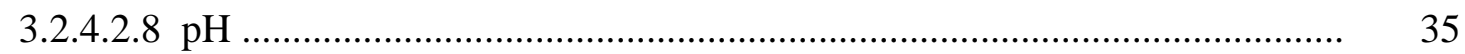

3.2.4.3 Granulometria ............................................................................. $\quad 35$

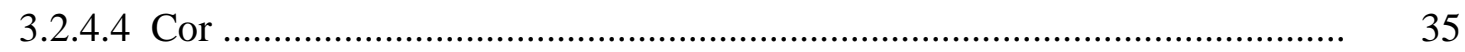

3.2.4.5 Índice de absorção de água (IAA) .......................................................... 36

3.2.4.6 Índice de solubilidade em água (ISA) .................................................... 36

3.2.4.7 Propriedades viscoamilográficas ............................................................. $\quad 37$

3.2.4.8 Grau de gelatinização (GG) ................................................................ 38

3.2.5 Características físicas dos extrusados ........................................................ $\quad 39$

3.2.5.1 Índice de expansão (IE) ...................................................................... 39

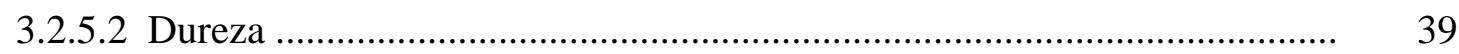

3.2.6 Delineamento Experimental .................................................................... 40

4 RESULTADOS E DISCUSSÃO .................................................................... 44

4.1 Caracterização da farinha de batata-doce não extrusada ................................... 44

4.1.1 Aspecto geral ................................................................................................ 44 


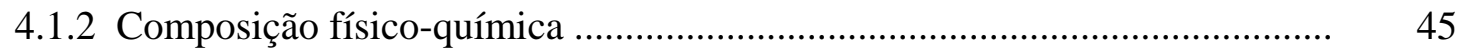

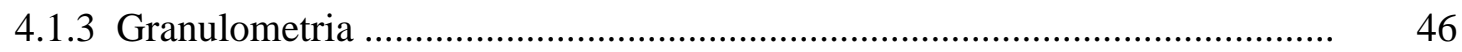

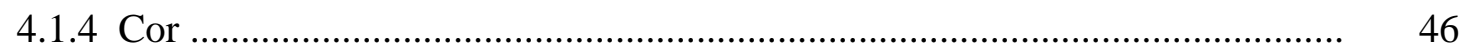

4.1.5 Índice de absorção (IAA) e índice de solubilidade em água (ISA) ............... 47

4.1.6 Viscoamilograma ................................................................................. 47

4.2 Características tecnológicas dos extrusados .................................................. 49

4.2.1 Aspecto geral ......................................................................................... 49

4.2.2 Índice de expansão e dureza ...................................................................... 50

4.2.2.1 Índice de expansão (IE) ....................................................................... 51

4.2.3 Dureza (DUR) .................................................................................. 54

4.3 Características tecnológicas das farinhas de batata-doce extrusadas ................ 56

4.3.1 Aspecto geral ........................................................................................... 56

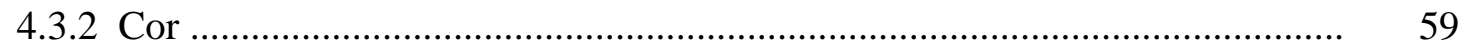

4.3.2.1 Componente $L^{*}$.................................................................................. 59

4.3.2.2 Valor de a* .................................................................................................. 61

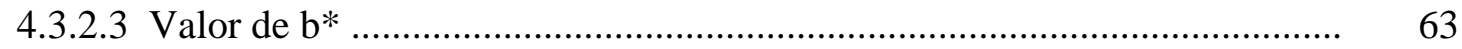

4.3.2.4 Diferença de cor (DCO) ............................................................................ 65

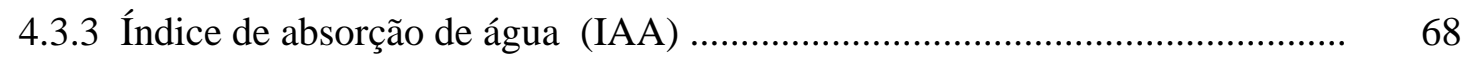

4.3.4 Índice de solubilidade em água (ISA) ....................................................... 70

4.3.5 Viscoamilograma ............................................................................ $\quad 72$

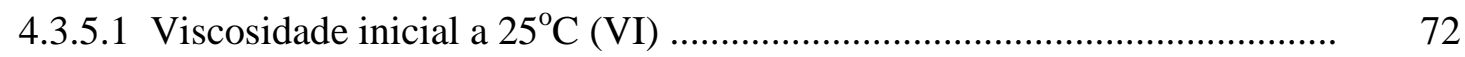

4.3.5.2 Pico de viscosidade (PV) .................................................................... $\quad 75$

4.3.5.3 Quebra de viscosidade (QV) ............................................................... 78

4.3.5.4 Tendência a retrogradação (TR) ………................................................... 81

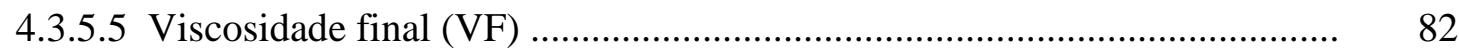

4.3.6 Grau de gelatinização $(\mathrm{GG})$........................................................................ 84

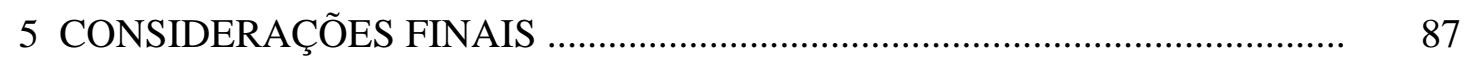

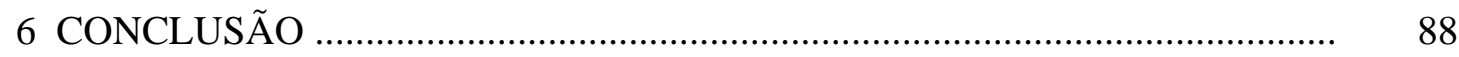

REFERÊNCIAS BIBLIOGRÁFICAS ……………...................................... 89 


\section{LISTA DE FIGURAS}

Página

1 Desenho esquemático de um extrusor de rosca simples .................... 8

2 Fluxograma de obtenção da farinha de batata-doce .......................... 31

3 Extrusor IMBRA RX utilizado para a extrusão da farinha de batatadoce

4 Parâmetros avaliados na curva amilográfica das farinhas de batatadoce não extrusadas e extrusadas

5 Aspecto da farinha de batata-doce não extrusada. A) aumento 20 x; B) aumento $100 \mathrm{x}$ e C) aumento $200 \mathrm{x}$

6 Perfil da curva de viscosidade de farinha de batata-doce não extrusada

7 Aparência dos extrusados nas diferentes condições do processo .......

8 Efeito da umidade das amostras e da temperatura de extrusão no índice de expansão dos extrusados de batata-doce, sob rotação de $210 \mathrm{rpm}$

9 Aspecto das farinhas de batata-doce extrusadas. A) aumento $20 \mathrm{x}$ (T8); B) aumento $100 \times$ (T8); C) aumento $200 \times$ (T5); D) aumento $500 \times$ (T8); E) aumento $500 \times$ (T3) e F) aumento $500 \times$ (T1)

10 Efeito do teor de umidade da matéria-prima sobre o componente $\mathrm{L}^{*}$ das farinhas extrusadas, sob condições de temperatura de $120^{\circ} \mathrm{C}$ e rotação de $210 \mathrm{rpm}$ 
11 Efeito do teor umidade sobre o parâmetro $\mathrm{a}^{*}$ das farinhas extrusadas, sob temperatura de $120^{\circ} \mathrm{C}$ e rotação de rosca de 210rpm

12 Efeito do teor de umidade da matéria-prima e a temperatura do extrusor no parâmetro b* das farinhas extrusadas, sob à rotação de $210 \mathrm{rpm}$

13 Efeito dos teores de umidade as amostras e temperatura de extrusão, na diferença de cor das farinhas de batata-doce, sob rotação de $210 \mathrm{rpm}$

14 Efeito dos teores de umidade da mistura sobre a viscosidade inicial das farinhas de batata-doce extrusadas, em temperatura de $120^{\circ} \mathrm{C}$ e rotação de $210 \mathrm{rpm}$

15 Efeito dos teores de umidade da mistura, em temperatura de $120^{\circ} \mathrm{C}$ e rotação de rosca de $210 \mathrm{rpm}$, sobre o pico de viscosidade das farinhas de batata-doce extrusadas

16 Efeito dos teores de umidade da matéria-prima sobre a quebra de viscosidade das farinhas de batata-doce extrusadas, sob temperatura de $120^{\circ} \mathrm{C}$ e rotação de rosca de $210 \mathrm{rpm}$

17 Efeito da rotação da rosca sobre a viscosidade final das farinhas extrusadas, sob teor de umidade de $18 \%$ e temperatura de extrusão de $120^{\circ} \mathrm{C}$ 


\section{LISTA DE TABELAS}

\section{Página}

1 Programa de extrusão, programação Extrusion 1 (sem álcool) e Extrusion 2 (com álcool)

2 Os níveis codificados e axiais e seus valores reais utilizados no experimento

3 Delineamento experimental do processo de extrusão de farinha de batata-doce

4 Composição físico-química da farinha de batata-doce

5 Granulometria da farinha de batata-doce

6 Índice de expansão e dureza dos extrusados dentro de cada tratamento de extrusão

7 Análise de variância dos fatores e regressão para o índice de expansão dos extrusados

8 Análise de Variância dos fatores e regressão para DUR dos extrusados.

9 Características das farinhas de batata-doce extrusadas dentro de cada tratamento de extrusão

10 Análise de Variância dos fatores e regressão para o componente L* das farinhas extrusadas

11 Análise de Variância dos fatores e regressão para o componente a* das farinhas extrusadas 
12 Análise de Variância dos fatores e regressão para o componente b* das farinhas extrusadas

13 Análise de Variância dos fatores e regressão estudadas para diferença de cor das farinhas

14 Análise de Variância dos fatores e regressão para IAA das farinhas extrusadas

15 Análise de Variância dos fatores e regressão para ISA das farinhas extrusadas

16 Análise de Variância dos fatores e regressão obtida para a viscosidade inicial das farinhas extrusadas

17 Análise de Variância dos fatores e regressão para pico de viscosidade das farinhas extrusadas

18 Análise de Variância dos fatores e regressão para quebra de viscosidade das farinhas extrusadas

19 Análise de Variância dos fatores e regressão para tendência a retrogradação das farinhas extrusadas

20 Análise de Variância dos fatores e regressão para a viscosidade final das farinhas extrusadas

21 Análise de Variância dos fatores estudos e da regressão para grau de gelatinização das farinhas extrusadas 


\section{EFEITO DE ALGUNS PARÂMETROS OPERACIONAIS NAS CARACTERÍSTICAS FÍSICAS, FÍSICO-QUÍMICAS E FUNCIONAIS DE EXTRUSADOS DA FARINHA DE BATATA-DOCE (Ipomoea batatas)}

Autora: ALEXANDRA MORELI BORBA

Orientadora: Prof $^{\text {a. }}$ Dr $^{\text {a. }}$ SILENE BRUDER SILVEIRA SARMENTO

\section{RESUMO}

A batata-doce é uma hortaliça de grande potencial energético, com elevado teor amiláceo e pode ser utilizada para consumo direto e para industrialização. Uma das tecnologias industriais viáveis para o processamento de alimentos amiláceos como a batata-doce, é a extrusão. Por este processo pode-se produzir snacks ou farinhas instantâneas (pré-gelatinizadas). O objetivo do presente trabalho foi avaliar o efeito dos parâmetros operacionais umidade da mistura, temperatura de processo e rotação do parafuso do extrusor sobre as características dos extrusados de batata-doce. As características avaliadas nos extrusados foram o índice de expansão (IE) e a dureza (DUR). As farinhas dos extrusados foram avaliadas quanto aos parâmetros: cor ( $\mathrm{L}^{*}, \mathrm{a}^{*}$, b* e diferença de cor, índice de absorção de água (IAA), índice de solubilidade em água (ISA), grau de gelatinização (GG) e pontos críticos de viscosidade (Rapid Visco Analyser), ou seja, viscosidade inicial (VI), pico de viscosidade (PV) após o aquecimento e antes do resfriamento, quebra de viscosidade (QV), tendência a retrogradação (TR) e viscosidade final (VF). Foi empregada a metodologia de superfície resposta, com delineamento fatorial incompleto $3^{3}$, de 3 níveis e 3 variáveis independentes: umidade (15, 18 e $21 \%)$, temperatura na $3^{\mathrm{a}}$ zona $\left(100,120\right.$ e $\left.140^{\circ} \mathrm{C}\right)$ e 
rotação da rosca (180, 210 e 240 rpm). O modelo de regressão adotado mostrou que a umidade e a temperatura afetaram significativamente o IE dos extrusados. Mantendo-se a rotação média constante, o IE aumentou com a elevação da temperatura do processo para misturas com baixos teores de umidade. Os menores valores de IE ocorreram para baixas umidades e temperaturas e também para elevadas umidades e temperaturas. $\mathrm{O}$ modelo de regressão adotado para DUR dos extrusados não foi significativo para os parâmetros estudados. Ao se avaliar as características tecnológicas das farinhas extrusadas, o IAA, o ISA e a TR não apresentaram modelo de regressão de significância estatística dentro dos níveis das variáveis independentes. As farinhas extrusadas apresentaram GG variando entre 82,0 e 99,7\%, contudo o modelo de regressão também não foi significativo para esta variável. Quanto a cor das farinhas extrusadas, o parâmetro L* (luminosidade) aumentou e o valor a* tendeu ao negativo (verde) com o aumento da umidade do material até aproximadamente 20-21\%. O componente b* tendeu ao positivo (amarelo) e a diferença de cor (DCO) das farinhas extrusadas aumentou com a redução da umidade da massa, independentemente da variação de temperatura de extrusão. Quanto aos parâmetros de viscosidade das farinhas extrusadas, a VI, o PV e a QV diminuíram com a elevação da umidade até 20-21\% e posteriormente, com elevação dos teores de umidade, mostraram aumento. Já a VF das farinhas extrusadas foi inversamente proporcional à rotação da rosca. O estudo mostrou que é viável a produção de extrusados de farinha de batata-doce com boas características utilizando-se os níveis das variáveis operacionais do processo. 


\title{
EFFECT OF SOME EXTRUSION PARAMETERS ON PHYSICAL, PHYSICO- CHEMICAL AND FUNCTIONAL PROPERTIES OF SWEET POTATO FLOUR EXTRUDED PRODUCTS
}

\author{
Author: ALEXANDRA MORELI BORBA \\ Adviser: Prof ${ }^{\mathrm{a} .} \mathrm{Dr}^{\mathrm{a}}$. SILENE BRUDER SILVEIRA SARMENTO
}

\section{SUMMARY}

The sweet potato is a vegetable of great energetic potential with high starch content. It can to be processed through extrusion which is efficient on the processing of starchy foods. In this work the effects of extrusion parameters on sweet potato extrudates and flours characteristics were studied. The properties evaluated in extrudates were expansion index (EI) and texture (hardness). The physical, physico-chemical and functional properties assayed in the extrudated flours were: water absorption index (WAI), water solubility index (WSI), color ( $\mathrm{L}^{*}, \mathrm{a}^{*}, \mathrm{~b}^{*}$ ) and color difference (CD), degree of gelatinization (DG) and pasting properties as initial viscosity (IV), raw peak (RP), breakdown (BD), setback (SB), cold viscosity (CV) and final viscosity (FV). The study was carried out by using Response Surface Methodology through an incomplete factorial design $3^{3}$ with 3 levels and 3 independent variables: moisture content $(15,18$, $21 \%)$, extrusion temperature $\left(100,120,140^{\circ} \mathrm{C}\right)$ and screw speeds $(180,210,240 \mathrm{rpm})$. The moisture content and extrusion temperature significantly affected expansion index of the extrudates.There was no influence of the parameters studied over extrudates hardness. The extrudates EI increased with the high extrusion temperature and low 
moisture content when the screw speed was medium. It decreased with the low moisture and temperature and at higher moisture content and temperature. The changes in independent variables did not result in significant regression model to extrudates hardness. The technological characteristics of extruded flours, WAI, WSI, SB and DG, did not present significant regression model to the parameters studied. The flours presented DG varying from 82.0 to $99.7 \%$. The $\mathrm{L}^{*}$ (lightness) component increased and value $\mathrm{a}^{*}$ decreased with the increase of the moisture content until $20-21 \%$. The color difference (CD) and parameter $b^{*}$ increased as the moisture content decreased, independent of the extrusion temperature. The IV, RP and BD values decreased with the increase the moisture until $20-21 \%$. The flour FV decreased as srew speed increased. The study showed that is viable the production of sweet potato extrudates with good characteristics using the independent variables of the process. 


\section{INTRODUÇÃO}

A batata doce (Ipomoea batatas) é uma hortaliça típica das regiões tropicais e subtropicais, rústica, de fácil manutenção e boa resistência contra a seca. Apresenta custo de produção relativamente baixo, com investimento mínimo, e retorno elevado (Miranda et al., 1995)

Devido ao grande potencial energético, a batata-doce desempenha papel importante na dieta, além de ser uma boa fonte de proteína, minerais e vitaminas (Iwe, 1998). Dentre os vários fatores citados na literatura em favor da utilização da batata-doce na dieta diária estão o bom rendimento agrícola potencial, grande quantidade de nutrientes por hectare, tolerância à seca e boa aceitabilidade dos consumidores devido a palatabilidade e baixo custo (Villareal, 1977).

Devido a sua composição e potencialidade agrícola, a batata-doce poderia ser utilizada como matéria-prima para diversos produtos alimentícios. No entanto, no Brasil, esta cultura fica restrita ao consumo direto. Sua industrialização é incipiente, sendo o produto mais conhecido o doce em pasta "marrom-glacê" (Figueira, 2000).

Um dos processos industriais que tem se mostrado muito eficiente na obtenção de produtos alimentícios industrializados é a extrusão, sendo viável no processamento de raízes e tubérculos amiláceos. Harper (1986) conclui que a extrusão é um processo versátil, efetivo e adaptado à carência de energia alternativa nos países subdesenvolvidos.

Segundo Harper (1981) a extrusão provoca alterações em várias propriedades funcionais do amido, as quais dependem principalmente da relação amilose e amilopectina e dos parâmetros operacionais do processo como a umidade da matéria prima, a temperatura do processo e a velocidade e a geometria do parafuso. 
A extrusão possibilita a obtenção de uma variedade de produtos como os snacks, farinhas pré-gelatinizadas, cereais pré-cozidos, entre outros.

As principais propriedades funcionais do amido extrusado quando disperso em água, são a absorção de água e a solubilidade em água. Assim, este absorve o líquido rapidamente, formando uma pasta a temperatura ambiente, sem qualquer aquecimento (Sebio, 1996). O aumento de solubilidade com a gelatinização é a base para a confecção de alimentos amiláceos instantâneos. Após a extrusão, as farinhas de alguns cereais são desidratadas e comercializadas como farinhas pré-gelatinizadas.

A necessidade de valorização de culturas tropicais de baixo custo de produção, aliada ao desenvolvimento de produtos alimentícios naturais, viabiliza estudos que busquem estes objetivos. Assim, no presente trabalho o objetivo foi avaliar o efeito de algumas condições de processamento nas características físicas, físico-químicas e funcionais de extrusados de farinha de batata doce. 


\section{REVISÃO DE LITERATURA}

\subsection{A cultura da batata-doce}

A família das Convolvuláceas agrupa aproximadamente 50 gêneros e mais de 1000 espécies. Dentre estas espécies, somente a batata-doce (Ipomoea batatas) tem cultivo de expressão econômica (Silva et al., 2002).

Há controvérsias em relação à origem da batata-doce. Segundo Barrera (1986) esta foi domesticada pelos indígenas da América do Sul (incas, maias e astecas), pois quando os europeus entraram em contato com os indígenas latino-americanos, estes já plantavam e se alimentavam da batata-doce. Mas segundo o autor, também há indícios que a origem seja africana e que a batata-doce fora trazida para terras americanas, antes da chegada dos europeus. Segundo o mesmo autor, outra possível origem da batata-doce é a Ásia, onde provavelmente foi domesticada e de onde ganhou a África e depois as Américas.

A espécie Ipomoea batatas é uma planta herbácea com caule rastejante, que atinge $3 \mathrm{~m}$ de comprimento, e folhas com pecíolos longos. Trata-se de uma planta perene, porém cultivada como anual (Figueira, 2000). É considerada uma cultura rústica, pois apresenta grande resistência a pragas, pouca resposta à aplicação de fertilizantes, e cresce em solos pobres e degradados (Silva et al., 2002).

A batata-doce possui dois tipos de raízes: a de reserva ou tuberosa, que constitui a parte de interesse comercial, e a raiz absorvente, responsável pela absorção de água e extração de nutrientes do solo. As raízes tuberosas se formam desde o início do desenvolvimento da planta, sendo facilmente identificadas pela maior espessura, pela pouca presença de raízes secundárias e por se originarem dos nós (Silva et al., 2002). 
A batata-doce é considerada uma das doze culturas mais importantes do mundo. De extrema importância social, ela é cultivada em quase todos os países, sendo vital para o suprimento alimentar da população, principalmente as mais carentes (Barrera, 1986).

Segundo dados da FAO (2001) a batata-doce é cultivada em 111 países, sendo aproximadamente $90 \%$ da produção obtida na Ásia, apenas 5\% na África e 5\% no restante do mundo. Apenas $2 \%$ da produção estão em países industrializados como os Estados Unidos e Japão. A China é o país que mais produz, com 100 milhões de toneladas/ano.

No Brasil, a batata-doce é cultivada em todas as regiões. Embora bem disseminada no país, está mais presente nas Regiões Sul e Nordeste, principalmente nos estados do Rio Grande do Sul, Santa Catarina, Paraná, Pernambuco e Paraíba (Silva et al., 2002).

O potencial de produção da batata-doce é enorme, por ser uma das plantas com maior capacidade de produzir energia por unidade de área e tempo (Miranda et al., 1995).

\subsubsection{Composição química da raiz de batata-doce}

Fonte de energia, minerais e vitaminas, a raiz de batata-doce apresenta composição química que varia com a cultivar, condições climáticas, época de colheita, tratos culturais, condições e duração de armazenamento (Miranda et al., 1995).

A batata-doce apresenta 59,1 a 77,7\% de umidade, 13,4 a 29,2\% de amido, 4,8 a $7,8 \%$ de açúcares redutores, 2,0 a 2,9\% de proteína, 0,6 a 1,7\% de cinzas, 1,3 a 3,8\% de fibra bruta e 0,3 a 0,8\% de matéria graxa (Kohyama \& Nishinari, 1992).

O conteúdo de aminoácidos de farinha de batata-doce, segundo Iwe et al. (2001) apresenta valores altos de ácido glutâmico, seguido de ácido aspártico, leucina e outros (prolina, arginina, lisina, valina etc).

A raiz tuberosa de batata-doce é um alimento à base de carboidratos sendo seu mais importante constituinte o amido. Os grânulos de amido de batata-doce podem apresentar os formatos arredondado, facetado e poliédrico, apresentando em sua maioria a última das formas mencionadas. O hilum é normalmente cêntrico, com as cruzes de 
polarização variando de fortes, nos grânulos redondos, para fracas, nos grânulos poliédricos. $\mathrm{O}$ amido de batata-doce apresenta excelentes propriedades adesivas, podendo também ser utilizado como substrato para a produção de álcool e de outros produtos industriais fermentados (Amante, 1986).

O amido da batata-doce pode apresentar valores de 15,7 a 21,6\% de amilose (Noda et al., 1997), ou 18\% de amilose (Gallant et al., 1982). Quanto à estrutura cristalina, os tubérculos como a batata-doce apresentam amido com estrutura tipo B. O conteúdo de amilose e amilopectina e suas estruturas afetam a arquitetura do grânulo de amido, sua gelatinização, perfil de pasta e atributos texturais (Thomas \& Atwell, 1997).

\subsubsection{Utilização comercial e tecnologia de processamento da batata-doce}

A cultura da batata-doce, ao longo do tempo, tem sido cultivada de forma empírica pelas famílias rurais, em conjunto com diversas outras culturas, visando o consumo direto, sendo utilizada na forma de raízes cozidas, assadas ou fritas (Silva et al., 2002). Na indústria, a batata doce pode ser a matéria prima para a produção de doces, pães, álcool e amido de alta qualidade, empregado na fabricação de tecidos, papel, cosméticos, adesivos e glicose em países asiáticos (Miranda et al., 1995).

De acordo com Barrera (1986) a importância da batata-doce é muito dependente do desenvolvimento tecnológico do país, pois este determina não só as exigências do mercado consumidor como também a qualidade dos sistemas de produção. Segundo o autor, no Brasil, embora a batata-doce venha sendo utilizada mais para a alimentação na forma natural, esta é alvo de intensas pesquisas, pois é uma alternativa altamente desejável para a produção de alimentos de baixo custo. Segundo Silva et al. (2002), entretanto, o investimento na cultura de batata-doce no Brasil é muito baixo e o principal argumento contrário ao investimento em tecnologia, é a lucratividade baixa. Segundo os autores, isto decorre da pequena produção individual, ou seja, os produtores ainda tendem a cultivar a batata-doce como cultura marginal, com o raciocínio de que, gastando-se o mínimo, qualquer que seja a produção da cultura constitui ganho extra. Desta forma, o produto obtido é de baixa qualidade e sofre restrições na comercialização, 
tanto por parte dos atacadistas, que tendem a reduzir o preço, quanto por parte do consumidor, que refuga parte do produto exposta à venda (Silva et al., 2002).

Segundo Sebio (1996) a introdução de tecnologias mais avançadas para o processamento das raízes e tubérculos está encontrando diversos graus de sucesso.

Segundo Iwe et al. (1998) consideráveis pesquisas têm sido dedicadas ao desenvolvimento de produtos de batata-doce. O consumo de batata-doce pode ser incrementado pelo desenvolvimento de novos produtos como os prontos para comer. Segundo os autores, pesquisas científicas prévias visando o aumento do consumo, buscam modificações e desenvolvimento de novos processos tecnológicos.

Um processo comumente utilizado para tubérculos e raízes é o da prégelatinização, usando a técnica dos rolos secadores ou Drum-Dryer. Esse processo, apesar de ser aparentemente simples, é difícil de controlar. Os custos operacionais e a manutenção são geralmente altos em relação à produção e o rendimento é baixo (Sebio, 1996).

A desidratação por secagem do rolo é menos eficiente que a extrusão-cocção, especialmente para o processamento de alimentos amiláceos. O uso de extrusores simples e de baixo custo pode aumentar a aprovação e popularização dessa cultura e prover uma solução para o problema de controle de qualidade do material cru, o qual geralmente sofre uma enorme perda pós-colheita (Iwe \& Ngoddy, 1998).

A produção de farinhas instantâneas de batata-doce poderá ser uma importante alternativa para a valorização da cultura, pois trata-se de processo de baixo custo e, que sendo um produto diferenciado, poderá atender a um mercado crescente de produtos naturais. 


\subsection{A extrusão}

O princípio básico do processo de extrusão é converter um material sólido em fluído pela aplicação de calor e trabalho mecânico e extrusá-lo através de uma matriz. O processo promove a gelatinização do amido, a desnaturação e re-orientação das proteínas, a inativação enzimática, a destruição de substâncias tóxicas tais como os inibidores das proteases e a diminuição da contagem microbiana para formar um produto de características físicas e geométricas pré-determinadas (Sebio, 1996). Além disso, proporciona a hidratação de amidos e proteínas, homogeneização, cisalhamento, fundimento de gorduras, plastificação e expansão da estrutura alimentar (Fellows, 2002).

Segundo Gutkoski (2000) dentre as aplicações da extrusão em alimentos, podese citar a produção de cereais matinais e expandidos, farinhas e amido pré-gelatinizados, produtos texturizados, produtos de confeitaria, bebidas, alimentos ricos em fibras. O processo pode também promover a inativação de fatores antinutricionais e de enzimas.

A transformação do material durante o processo de extrusão ocorre em três etapas: a plastificação, onde o material sólido em qualquer estado nativo (grânulo ou pó), torna-se um líquido homogêneo pelo fundimento, como processo físico principal; o modelamento do material em estado fundido pela passagem através da matriz; e por fim, o cozimento e a texturização do produto (Colonna et al., 1987).

O extrusor consiste de um parafuso de Arquimedes que gira dentro de um cilindro estacionário. Sob condições de alta temperatura, pressão e de forças de cisalhamento, termina por dar forma ao material quando este é forçado a passar através de um molde (Baruffaldi \& Oliveira, 1998).

Segundo Gutkoski (2000) o extrusor é constituído basicamente pelo alimentador, parafuso ou rosca, cilindro encamisado, matriz e mecanismo de corte. $\mathrm{Na}$ Figura 1 está representado de forma esquemática um extrusor de rosca simples.

O alimentador é composto de um recipiente para receber o material a ser extrusado e de um parafuso ou vibrador, localizado vertical ou horizontalmente. Tem a função de manter a alimentação constante e ininterrupta, o que é essencial para o funcionamento do extrusor, bem como para a homogeneidade e a qualidade do produto (Gutkoski, 2000). 


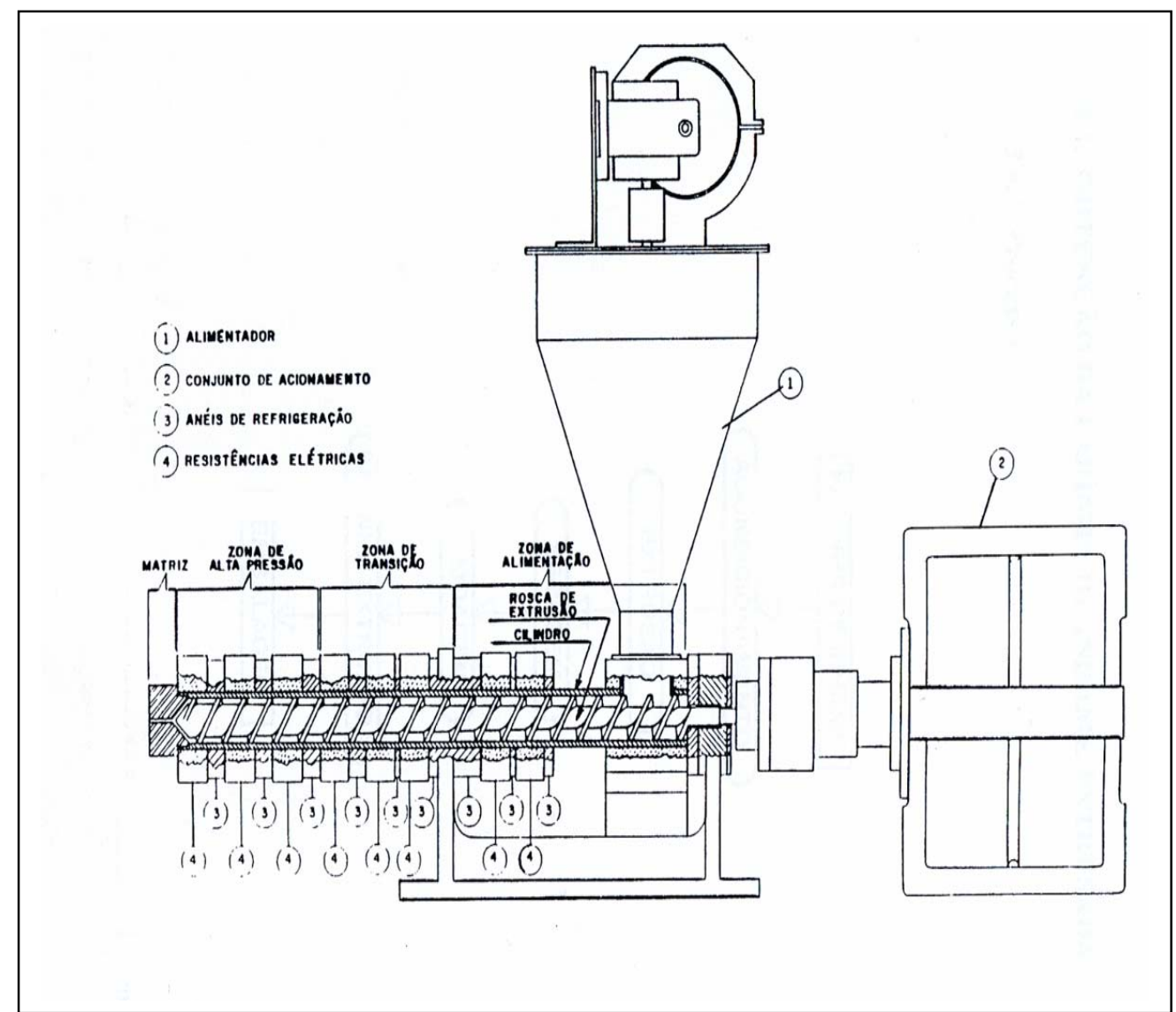

Figura 1 - Desenho esquemático de um extrusor de rosca simples

Fonte: Sebio (1996)

O parafuso ou rosca, considerado a parte mais importante do extrusor, ajuda a regular o grau de cozimento, a gelatinização e a qualidade final do produto. Este mistura continuamente o material e o conduz pelo cilindro, gerando fricção mecânica e calor, que ajudam a fundir o produto (Gutkoski, 2000).

O cilindro encamisado envolve o parafuso e é dividido em seções para permitir a circulação de vapor, óleo, água ou ar, itens que colaboram para o ajuste perfeito de temperatura entre as várias zonas do extrusor (Gutkoski, 2000). 
A matriz apresenta configurações variadas e, além de moldar o produto na forma desejada, funciona como um restritor de fluxo, mantendo a pressão na zona de cocção (Gutkoski, 2000).

O mecanismo de corte está acoplado à porção final do extrusor, sendo constituído por lâminas horizontais ou verticais que, de acordo com a velocidade de giro, determinam o comprimento do produto. Uma maior velocidade vai originar produtos mais curtos e vice-versa. O mecanismo deve prover corte do produto em comprimento uniforme e com superfícies perfeitas (Gutkoski, 2000).

$\mathrm{Na}$ literatura podem ser encontrados vários tipos de classificação para os extrusores.

Fellows (2002) classifica os extrusores de acordo com o método de operação em extrusores a frio ou extrusores de cocção. $\mathrm{Na}$ extrusão a frio, o extrusor tem um parafuso que opera a baixa velocidade em um cano liso, para amassar e extrusar o material com pequena friç̧ão e temperaturas abaixo de $100^{\circ} \mathrm{C}$. Este é usado para produzir pastas, massas de bolo, alcaçuz, pasta de peixe, ração animal e alguns tipos de doces.

Se o alimento for aquecido acima de $100^{\circ} \mathrm{C}$, o processo é conhecido como extrusão-cocção (ou extrusão à quente). Neste caso, o calor é proporcionado pela fricção ou pela adição de calor, aumentando a temperatura rapidamente. A extrusão-cocção sob alta pressão e temperatura em curto período de tempo (HTST) é usada para formar produtos expandidos. A rápida liberação de pressão quando o alimento emerge da matriz causa expansão instantânea e forma um produto de baixa densidade. A extrusão por HTST é usada para se obter produtos gelatinizados, mastigáveis, como gomas de frutas e alcaçuz (Fellows, 2002).

Segundo Baruffaldi \& Oliveira (1998) os extrusores são classificados em termodinâmicos ou operados com pressão. Termodinamicamente os extrusores dividemse em três grupos, ou seja, autógenos, isotérmicos e politrópicos. Os extrusores autógenos (aproximadamente adiabáticos) são aqueles em que o calor total que entra no extrusor resulta da dissipação viscosa da energia mecânica e pouco ou nenhum calor deve ser adicionado ou removido do cilindro. Os extrusores isotérmicos são aqueles onde a temperatura do processo é mantida constante por camisas de água que removem o calor 
produzido. Os extrusores politrópicos são aqueles onde o calor é adicionado ou retirado do extrusor.

Segundo Baruffaldi \& Oliveira (1998) os extrusores podem ser ainda agrupados em cinco categorias de acordo com as suas características operatórias:

- Extrusores para massas alimentícias, que consistem de um cilindro liso e parafuso operando em baixa velocidade. Isto favorece o trabalho da farinha que deve passar através do molde sem sofrer forte cozimento.

- $\quad$ Extrusores de alta pressão, que possuem capacidade de alta compressão, resultando em altas pressões na saída da matriz.

- $\quad$ Extrusores - cozedores sob baixo cisalhamento, usados para materiais de baixa viscosidade. $\mathrm{O}$ calor pode ser adicionado ao extrusor.

- Extrusores collet, que possuem parafuso pequeno com poucas aletas. A dissipação do calor ocorre rapidamente. São usados na extrusão de materiais secos.

- $\quad$ Extrusores - cozedores de alto cisalhamento, projetados para operar em altas taxas de compressão e com capacidade de aquecer e resfriar o cilindro. Estes extrusores têm grande versatilidade, podendo trabalhar em condições variáveis e aceitar ingredientes com teor variável de umidade.

\subsubsection{O Processo de extrusão}

Segundo EL-Dash (1982) o processo de extrusão compreende as etapas de préextrusão, extrusão e pós-extrusão. A pré-extrusão inclui a preparação dos ingredientes e sua mistura em proporção adequada. Após a mistura, o material é transportado para ser condicionado a um conteúdo apropriado de umidade. Na etapa de extrusão, a matériaprima é introduzida no equipamento através do alimentador, sendo impulsionada pelo(s) parafuso(s) em direção à matriz. À medida que o produto atravessa as diferentes zonas de extrusão (de alimentação, de transição e de alta pressão), ocorre aumento gradativo do atrito mecânico, provocado por modificações da geometria do parafuso e abertura da matriz. Em conseqüência, aumentam também a pressão e a temperatura, ocorrendo o 
cozimento do produto. A pós-extrusão inclui a secagem dos extrusados para umidades inferiores a 10\%, o resfriamento e a aplicação de sabores e temperos.

Agentes de coloração e sabor podem ser adicionados aos ingredientes da mistura e depois de homogeneizados, são extrusados e resfriados. A cor é determinada por pigmentos sintéticos que são adicionados ao material alimentar sob a forma de pós solúveis em água ou óleos emulsificantes. A adição de saborizantes é realizada antes da extrusão a frio, mas isto não tem muito sucesso na extrusão-cocção, pois os aditivos são volatilizados quando o alimento passa pela matriz. Os agentes de sabor são, portanto, mais aplicados à superfície do produto extrusado sob a forma de emulsificantes por spray (Fellows, 2002).

De acordo com Yacu (1990) as variáveis do processo de extrusão que controlam diretamente os atributos de qualidade são chamadas de variáveis independentes. Estas incluem a composição dos ingredientes alimentares, sua umidade, o tamanho de suas partículas, a velocidade de alimentação do parafuso, a configuração do parafuso e da matriz, a temperatura, a pressão e o tempo de residência.

Por outro lado, as variáveis dependentes ou respostas mudam como conseqüência das variáveis independentes e servem para avaliar as propriedades físicas, químicas e funcionais dos extrusados. Entre estas incluem-se: densidade, volume específico, umidade, expansão, os atributos sensoriais como aparência, sabor, crocância e textura, o grau de cozimento, avaliado através da susceptibilidade enzimática, viscosidade, índices de absorção e de solubilidade em água, a difração de raio-X e calorimetria (Yacu, 1990).

\subsubsection{Vantagens e aplicações da extrusão}

A utilização da extrusão pela indústria de alimentos difundiu-se muito nos últimos anos por apresentar uma série de vantagens em relação aos processos tradicionais. Trata-se de um processo contínuo com pouco ou nenhum resíduo, baixos requerimento de mão de obra e de espaço por unidade de produção, alta capacidade de produção por unidade de área, sendo considerado de baixo custo em comparação com 
outros processos de cocção, pois converte eficientemente a energia elétrica em energia térmica (Stanley, 1986 ).

A habilidade do extrusor de trabalhar um número variado de ingredientes e condições de processamento, assegura sua versatilidade e alarga sua aplicabilidade a uma grande cadeia de produtos alimentares (Harper, 1978). O extrusor processa materiais relativamente secos ou viscosos, melhora as características de sabor e textura dos alimentos (Stanley, 1986 ). O processo de extrusão HTST desnatura as enzimas que causam rancidez ou outras deteriorações nos alimentos, inativa fatores antinutricionais, como os inibidores de tripsina em soja e a causa morte de microrganismos presentes no alimento, trazendo ao produto esterilidade ou reduzindo a população microbiológica (Harper, 1978).

Segundo Harper (1978) o extrusor alcança alta produtividade em uma única operação, onde ambos, cozimento e modelagem, ocorrem aumentando a eficiência do processo. São exemplos, as características de expansão e crocância apresentadas pelos snacks e cereais matinais. Outra área de alimentos extrusados é a texturização de proteínas vegetais que produz um tipo de fibra com estrutura similar à da carne.

A produção de propriedades texturais é uma das muitas características da tecnologia de extrusão. A textura do produto pode ser ajustada de macia a elástica pelo controle da formulação e das condições do processamento e a forma do produto pode ser modificada por alterações na matriz. Estas combinações diferentes permitem uma grande variedade de produtos, incluindo alcaçuz, doces cozidos, cremes, chocolates etc. (Fellows, 2002).

Outros produtos gerados pela extrusão são os cereais matinais, produzidos em extrusores de baixa pressão e os alimentos a base de proteínas. Nas proteínas texturizadas de soja, a extrusão-cocção destrói as enzimas presentes em sementes de soja, incluindo a urease a qual reduz a vida útil do produto, a lipoxidase que causa off flavors, por oxidação do óleo de soja e também destrói o inibidor de tripsina, que reduz a digestibilidade da proteína. Assim, ocorre melhoria na digestibilidade e aceitabilidade do alimento e aumenta sua vida útil (Fellows, 2002). 


\subsubsection{Impacto do processo sobre o valor nutricional dos extrusados}

Quanto ao valor nutricional, a perda de vitaminas nos extrusados varia de acordo com o tipo de matéria - prima, teor de umidade que apresentam, temperatura e tempo do processo. Geralmente as perdas são minimizadas na extrusão a frio. As condições de HTST na extrusão-cocção e o rápido esfriamento do produto quando emerge da matriz, causam perda relativamente pequena de vitaminas e aminoácidos essenciais (Fellows, 2002).

Altas temperaturas e presença de açúcares causam o escurecimento do extrusado pela reação de Maillard e redução na qualidade das proteínas. Baixas temperaturas e concentração de açúcares resultam em aumento da digestibilidade da proteína devido à reorganização da estrutura protéica (Fellows, 2002).

Iwe et al. (2001) observaram que o processo de extrusão da batata-doce reduziu drasticamente o teor de aminoácidos da mesma.

A extrusão de farinha de trigo ou centeio sob condições drásticas promove aumento na quantidade de fibra total e conversão significativa das frações insolúveis a solúveis. Tratamentos mecânicos e térmicos intensivos, geralmente aumentam a acessibilidade e digestibilidade do amido (Gibson \& Williams, 2000). Em alguns casos, o cozimento leva à formação de complexos físicos ou químicos entre o amido e outros compostos, por exemplo, lipídeos e proteínas. Complexos semelhantes podem ser resistentes aos ataques por enzimas amilolíticas e este "amido resistente" constitui área de interesse como fibras dietéticas (Galliard, 1987).

O efeito significativo da solubilização de amidos de cereais pela extrusãococção é importante para a alta digestibilidade total na nutrição humana, e a complexação da amilose é importante para a palatibilidade. No entanto, não há informações disponíveis a respeito da qualidade nutricional dos amidos extrusados, em termos de cinética da digestão (Colonna et al., 1987). A extrusão-cocção de farinha pode gerar amido com maior digestibilidade do que o cozimento convencional (Galliard, 1987). 


\subsubsection{Fatores que interferem na qualidade dos produtos extrusados}

Dois fatores que mais influenciam a natureza dos produtos extrusados são as propriedades reológicas da matéria-prima e as condições de operação do extrusor (Fellows, 2002).

As propriedades reológicas da matéria-prima têm importante influência na textura e coloração do produto. Os fatores mais importantes são tipo, teor de umidade, estado físico e composição química, particularmente a quantidade e tipo de amido, proteínas, gorduras e açúcares. $\mathrm{O}$ pH do material umidificado também interfere (Fellows, 2002).

A umidade tem um efeito pronunciado nas características dos extrusados. Geralmente, baixos valores de umidade estão relacionados ao maior grau de dextrinização e menor viscosidade da pasta a frio (El-Dash, 1982). Segundo Onwulata et al. (2001) a umidade exerce grande influência na qualidade do extrusado por afetar a estrutura celular e a fragilidade dos produtos expandidos. Uma das funções da água é criar bolhas de ar, o que leva a diferenças na expansão (Colonna et al., 1984). O aumento da umidade diminui o grau de degradação do amido durante o aquecimento e cisalhamento devido a redução do estresse, que promove redução da viscosidade (Van den Einde et al., 2004).

A composição da matéria-prima, seu teor de umidade e tamanho de suas partículas influenciam a viscosidade do produto no extrusor. A viscosidade é um fator crucial, que determina as condições de operação do extrusor, e portanto, a qualidade do produto final. Diferentes tipos de matérias-primas geram produtos completamente diferentes quando algumas condições de operações do extrusor são usadas. Isto decorre dos diferentes tipos e teores de amido e de proteínas, teores de umidade e outros ingredientes adicionados (por exemplo, óleo e emulsificantes), o que resulta em diferentes viscosidades e características de fluxo. Semelhantemente, a adição de ácidos para ajuste do $\mathrm{pH}$ causa mudanças na gelatinização do amido e no desdobramento de moléculas de proteínas. Diferenças no conteúdo de açúcares e no pH também produzem variação de cor devido a Reação de Maillard (Fellows, 2002). 
Partículas pequenas, como as farinhas, são hidratadas mais facilmente e cozidas mais rapidamente que partículas maiores, alterando também a qualidade do produto. A gelatinização do amido normalmente causa aumento na viscosidade, mas em extrusãococção, o intenso cisalhamento também pode quebrar as macromoléculas em unidades menores, resultando na redução da viscosidade (Fellows, 2002).

O controle do processo de extrusão é uma tarefa fundamental, pois não somente permite a obtenção de produtos com características tecnológicas variadas, mas também melhora a eficiência e economia da operação (El-Dash, 1982). Segundo Fellows (2002) os parâmetros de operação mais importantes no extrusor são temperatura, pressão, diâmetro da matriz e cisalhamento, além do desenho do parafuso e tempo de retenção (El-Dash, 1982).

A temperatura de extrusão é um elemento fundamental para o controle das várias características tecnológicas como o grau de cocção e a expansão (EL-Dash, 1982).

A intensidade de pressão dentro do cilindro depende, em parte, do tamanho da matriz. Se o cilindro for completamente aberto na matriz final, não haverá pressão e o extrusor simplesmente agirá como um parafuso transportador. Inversamente, se a matriz final for completamente fechada, a pressão aumentará. Entre estes dois extremos, o tamanho da matriz afeta grandemente o desempenho do extrusor (Fellows, 2002).

O cisalhamento é influenciado pelo desenho do cilindro, o comprimento, a velocidade e a geometria do parafuso (Fellows, 2002).

A função, a eficiência e a capacidade de um extrusor dependem, em larga extensão, do desenho do parafuso e de seu revestimento, os quais governam o mecanismo de fluxo. O parafuso é provavelmente a parte mais importante do extrusor, pois este governa não somente o grau de cocção e a gelatinização, mas também a característica de qualidade do produto final. Alguns valores de temperatura do extrusor e umidade do produto requerem um tempo mínimo de retenção no extrusor para obter um grau específico de gelatinização (EL-Dash, 1982).

O tempo de residência do produto no extrusor é uma função do modelo do parafuso e de sua velocidade de rotação. Normalmente, o tempo de residência varia de 60 a 270 segundos (Harper, 1978). 
Embora o processo de extrusão seja basicamente uma simples operação tecnológica, seu controle é complicado. Isto decorre das inúmeras variáveis envolvidas no processo e do fato de que a influência da maioria delas sobre o processo não é conhecida. Outro fator é a complexa natureza do sistema alimentar, onde várias mudanças químicas e físicas ocorrem simultaneamente durante o processo de extrusão (EL-Dash, 1982).

\subsection{Amido}

O amido é o produto final do processo fotossintético e constitui a reserva de carbono nas plantas. Sua formação ocorre devido a atividade combinatória de algumas enzimas, tanto nas organelas fotossinteticamente ativas, onde o amido é reserva temporária, quanto nos amiloplastos de órgãos de reserva (Franco et al., 2001).

O amido armazenado nas células de sementes, raízes, tubérculos, acha-se depositado na forma de grânulos mais ou menos brilhantes, apresentando formas e dimensões diversas. A estrutura do grânulo de amido está intimamente ligada ao seu desenvolvimento na célula viva. Nas células vegetais, os grânulos são formados dentro de estruturas especiais denominadas amiloplastos, envolvidos por uma matriz protéica, o estroma (Franco et al., 2001).

Os grânulos de amido são estruturas semi-cristalinas compostos de macromoléculas lineares e ramificadas. Essas moléculas formam pontes ou ligações de hidrogênio, pois estão associadas paralelamente, o que resulta no aparecimento de regiões cristalinas ou micelares. Quanto à sua estrutura química, o amido é composto por resíduos de $\alpha$-D-glucose, formando dois tipos de macromoléculas, a amilose e a amilopectina (Franco et al., 2001).

A amilose é um polissacarídeo composto de unidades de $\alpha(1-4)$ D-glicose unidas em longas cadeias predominantemente lineares. A amilose apresenta a propriedade de absorver até 25 vezes seus peso em água (Franco et al., 2001). O peso 
molecular da amilose é de $10^{5}$ a $10^{6}$ e com número de resíduos de glicose por molécula estendendo para 500 a 5000 (Galliard \& Bowler, 1987).

A amilopectina é formada por ligações $\alpha(1-4)$ nas porções retilíneas e ligações $\alpha(1-6)$ nas ramificações. De cada 20 a 30 moléculas de glicose ocorre um ponto de ramificação. Essa característica a torna menos susceptível à ação de certas enzimas do que a amilose, o que é um fator importante para explicar a ação de enzimas sobre o amido e sua aplicação em processos industriais (Franco et al., 2001). A amilopectina tem peso molecular de $10^{7}-10^{9}$, dependendo da fonte botânica (Galliard \& Bowler, 1987).

Segundo Galliard \& Bowler (1987) no amido extraído há também os componentes menores, que podem ser divididos em três categorias: partículas de material, que são fragmentos de material não amiláceo; componentes de superfície, que são materiais associados à superfície de grânulos e que podem ser removidos por procedimentos de extração que não causem rompimento da estrutura granular e, componentes internos, que são materiais localizados dentro da matriz granular e são inacessíveis a extração sem fragmentação do grânulo.

\subsubsection{Influência dos componentes do amido e as interações moleculares do amido durante o processo de extrusão}

Segundo Gomez \& Aguilera (1983) há pouca informação sobre as mudanças que ocorrem na fração amido dos alimentos durante a extrusão, embora as propriedades físicas e sensoriais dos extrusados dependam da extensão da degradação deste polímero.

Durante a extrusão-cocção, o amido que inicialmente se encontra na forma granular quando na presença de umidade, é progressivamente comprimido e transformado em um material denso, sólido, compacto e a estrutura granular cristalina desaparece (Colonna et al., 1987).

Os amidos de diferentes fontes diferem entre si quanto à forma do grânulo, à proporção amilose-amilopectina e à propriedade de expansão. Cada amido é considerado único. Devido a isto, a seleção do amido é crítica, principalmente quanto ao controle do 
conteúdo de amilose e de amilopectina, já que ambos os polímeros contribuem para os atributos finais dos produtos extrusados (Thomas \& Atwell, 1997).

O teor de amilose é normalmente responsável pela resistência física da mistura. Aumentar o teor de amilose na formulação torna as moléculas mais resistentes à degradação pelo cisalhamento durante a extrusão e pode contribuir com a melhoria do corte e da retenção da forma durante a secagem ou durante o processamento final, como o cozimento ou fritura (Thomas \& Atwell,1997). Segundo Della Valle et al. (1997) os produtos amiláceos podem expandir diferentemente de acordo com o seu conteúdo de amilose, sendo que esta diferença pode ser atribuída as propriedades viscoelásticas da molécula.

O componente amilose melhora a leveza, elasticidade, regularidade da superfície e textura. Em contraste, a amilopectina acarreta dureza e perda do poder de expansão nos produtos extrusados (Colonna et al., 1987). De acordo com Li \& Yeh (2001), aparentemente, o inchamento que ocorre no grânulo de amido é uma propriedade da amilopectina. As áreas cristalinas estabelecidas pelas moléculas de amilopectina determinam o início do inchamento e da gelatinização do amido.

A amilopectina no amido gelatinizado forma uma rede que aumenta a viscosidade do produto. Por ser um polímero ramificado, a amilopectina é susceptível à degradação no cisalhamento durante a extrusão, resultando em dextrinas e polímeros de cadeias curtas, o que dificulta a operação de corte após a extrusão (Thomas \& Atwell,1997).

Dentre as interações de importância do amido no processo de extrusão estão as interações eletrostáticas do tipo ponte ou ligação de hidrogênio que ocorrem entre as hidroxilas geralmente expostas na parte externas das estruturas em hélice formada pelas macromoléculas de amilose e amilopectina. Essas interações são responsáveis pela formação da rede tridimensional que confere estrutura ao produto. A regularidade e a freqüência com que ocorrem permitem uma alta expansão do produto na saída do equipamento. Dada às suas características, essas interações são facilmente rompidas por água, fazendo com que produtos altamente expandidos contendo predominantemente amido desintegrem-se facilmente quando umedecidos (Arêas, 1996). 
O amido pode também interagir durante a extrusão com lipídeos ou outras espécies apolares, capazes de ocupar a região interior das hélices formadas pelas macromoléculas de amilose e amilopectina. Os lipídeos que melhor interagem com o amido são os monoglicerídeos e a sua presença é benéfica ao produto quando sua concentração ainda não atingiu o limite de saturação das hélices. Quando os lipídeos estão presentes em concentrações além da capacidade de interação das hélices, a sua presença prejudica o processo e diminui a expansão do produto (Arêas, 1996). Segundo Colonna et al. (1987) onde os lipídeos estão presentes, as modificação são menores, sugerindo que estes podem agir como lubrificantes na extrusão, sendo que cada tipo de lipídeo tem um efeito distinto. A adição de baixos níveis de lipídeos pode beneficiar o processo de extrusão de amido-proteína por prevenir a formação de materiais insolúveis (Thymi et al., 2005).

A interação de amido e polissacarídeos em geral com proteínas pode gerar o aparecimento de duas fases em soluções aquosas devido à incompatibilidade termodinâmica que se observa entre alguns polissacarídeos e proteínas. A presença de certos polissacarídeos, principalmente carregados, até mesmo em concentrações pequenas, pode prejudicar consideravelmente a extrusão de proteínas, compactando o produto. Esta compactação ocorre devido a interação polissacarídeos/proteínas que, pela separação de fases, tende a reduzir o volume ocupado pelas proteínas na solução, reduzindo assim a expansão do produto final. Geralmente a extrusão de grande quantidade de amido na presença de menor quantidade de não interfere no processo pelo menos quanto às características do produto final (Arêas, 1996).

\subsubsection{Modificações químicas e físicas do amido extrusado}

Os grânulos de amido nativos são insolúveis em água à temperatura ambiente, altamente resistentes à hidrólise ácida e carentes de propriedades funcionais específicas. $\mathrm{O}$ amido em sua forma nativa é relativamente inerte, entretanto, pode ser modificado por tratamentos que rompem a estrutura granular e conferem propriedades funcionais 
específicas. Estes tratamentos podem ser processos físicos, químicos ou enzimáticos (Colonna et al., 1987).

As modificações físicas de amido envolvem ação simultânea de temperatura, pressão, cisalhamento e umidade. Segundo Colonna et al. (1987) o efeito destes processos em vários amidos (como cereais e tubérculos) induz dois tipos de transformação, a modificação da estrutura física com a conservação ou completa desorganização do grânulo e a modificação em nível molecular envolvendo degradação das macromoléculas ou de monômeros. Um dos processos que causa modificações da estrutura física com destruição da forma granular é a extrusão.

Na extrusão de HTST, a gelatinização do amido acontece muito rapidamente, já que o material é aquecido em condições adiabáticas e submetido a tensões de cisalhamento que, com a combinação de tipos de amido, umidade, temperatura e pressão, além de outros fatores intrínsecos do extrusor, propiciam, entre outras mudanças, a obtenção de um produto final com características específicas de textura, densidade e expansão (Ascheri, 1994)

O amido nativo não absorve água a temperatura ambiente e sua viscosidade é praticamente zero, entretanto, o amido extrusado absorve água rapidamente formando uma pasta a temperatura ambiente pelas macromoléculas solubilizadas e partículas entumescidas por água. O amido extrusado, de acordo com as condições do processo, sofre transformações químicas que causam entumescimento e ruptura dos grânulos, modificações das estruturas cristalinas provocando solubilidade e viscosidade em água fria (Sebio, 1996). A extrusão destrói a estrutura cristalina organizada de modo parcial ou total, dependendo da proporção amilose-amilopectina e das variáveis de processo (Colonna et al., 1987).

A amilose e a amilopectina são quebradas em materiais de baixo peso molecular pela extrusão-cocção. A dimensão da quebra macromolecular ocorre em função de parâmetros da extrusão como a temperatura e a velocidade do parafuso (Colonna et al., 1987).

Segundo Colonna et al. (1984) o monômero D-glucose medido em materiais extrusados através de método enzimático foi recuperado completamente. $\mathrm{O}$ teor de amido 
não é alterado durante o processo, o que demonstra que nenhuma nova ligação foi formada apesar das condições de altas temperaturas, propícias aos rearranjos moleculares (Sebio, 1996). Também as proporções ligações $\alpha(1-4) / \alpha(1-6)$ não foram modificadas durante a extrusão (Colonna et al., 1984).

Em amidos de tubérculos (batata e mandioca) que são livres de lipídeos e amido de milho que não contém amilose, a redução da cristalinidade é observada à baixas temperaturas de extrusão. Em altas temperaturas, estas estruturas são destruídas completamente, levando a uma difração de raio-X típica de uma fase amorfa. Amidos com conteúdos normais de amilose comportam-se de modo totalmente diferente. Dois tipos de estrutura podem ser formados. Abaixo de $170^{\circ} \mathrm{C}$, uma difração de raio-X característica da estrutura de amido tipo V aparece. Em contraste, acima de $185^{\circ} \mathrm{C}$, uma nova estrutura chamada "extrusada" ou tipo E é observada. Esta é caracterizada por três picos de difração ligeiramente deslocados daqueles picos apresentados pelo tipo V. A $170^{\circ} \mathrm{C}$ ambos os tipos, $\mathrm{E}$ e V, ocorrem. Entretanto, o recondicionamento do produto a $30 \%$ de umidade sempre transforma a estrutura tipo E em tipo V estável (Colonna et al., 1987).

A similaridade entre os tipo $\mathrm{E}$ e $\mathrm{V}$ faz supor que a estrutura extrusada seja helicoidal, como a estrutura tipo B, com seis resíduos de glicose por ciclo em uma simetria hexagonal. A diferença entre as duas estruturas poderia ser devido à distância interaxial nas duas hélices. De acordo com dados de difração de raio-X, a distância interaxial para tipos $\mathrm{V}$ e tipos E são 1,38 nm e 1,50 nm, respectivamente (Colonna et al., 1987).

Estudos com difração de raio-X sugerem que durante a extrusão, a estrutura de amidos de cereais é reorganizada assim que a fração amilose é convertida em um complexo helicoidal do tipo V. Já a estrutura tipo E é mais causada por variações nas distâncias inter-hélices que pela presença de dois tipos diferentes de hélices (Colonna et al., 1987). 


\subsubsection{Algumas propriedades funcionais e físico-químicas do amido extrusado}

Algumas das propriedades físicas, físico-químicas e funcionais do amido envolvidas na extrusão são: textura, gelatinização, viscosidade, índice de absorção de água, índice de solubilidade em água, expansão e cor.

A textura é um elemento importante na qualidade dos alimentos, afetando diretamente sua aceitabilidade pelos consumidores e sua venda (Gaines et al., 1992). O que se deseja em snacks com boas características é que os valores de fraturabilidade e dureza sejam baixos (Alves \& Grossman, 2002).

Segundo Chang \& El-Dash (2003) a dureza é influenciada pelo índice de expansão e pelo alinhamento das camadas de amido para a formação da estrutura final.

Sebio (1996) observou em extrusados de farinha de inhame que os maiores valores de dureza foram obtidos à baixas temperaturas $\left(100^{\circ} \mathrm{C}\right)$ e alta umidade $(26 \%)$ e os menores valores de dureza foram obtidos à altas temperaturas $\left(150^{\circ} \mathrm{C}\right)$ e baixas umidades $(18 \%)$.

A gelatinização é o processo de transformação do amido granular em pasta viscoelástica. Durante o aquecimento de dispersões de amido em presença de excesso de água, inicialmente ocorre o inchamento de seus grânulos, com destruição da ordem molecular e mudanças irreversíveis nas suas propriedades. A temperatura na qual ocorre este tipo de transformação é chamada de temperatura de gelatinização (Souza \& Andrade, 2000). A faixa de temperatura de gelatinização do amido é uma característica do genótipo da planta na qual o amido é sintetizado e é afetada pelas condições do meio, especialmente a temperatura durante o desenvolvimento do grânulo (Franco et al., 2001).

Collado et al. (1999) analisando parâmetros de gelatinização de amidos de 44 genótipos de batata doce observaram uma faixa de temperatura de gelatinização de 64,7 a $84,6^{\circ} \mathrm{C}$ e $\Delta \mathrm{H}$ de $12,9 \mathrm{~J} / \mathrm{g}$.

Segundo Franco et al. (2001) o aquecimento de suspensões de amido em excesso de água (maior que 60\%) causa a gelatinização, que é uma transição irreversível. Com o aumento progressivo da temperatura, há rompimento dos grânulos, que se transformam em substâncias gelatinosas, um tanto opalescente à qual se dá o nome de goma ou pasta de amido (Souza \& Andrade, 2000). Com isto, ocorre alterações 
estruturais significativas no amido, destruindo as cadeias de polímeros e permitindo sua liberação (Gomez \& Aguilera, 1983). Esta alteração depende essencialmente de três fatores principais, a temperatura, a umidade da mistura e a origem botânica do amido (Colonna et al., 1987).

Em alimentos, amidos gelatinizados podem ser usados sempre que o espessamento for desejado. A gelatinização do amido também afeta significativamente as características e qualidade dos alimentos como volume dos pães, a elasticidade e maciez dos produtos de pasta, a digestibilidade e a palatabilidade, a tolerância das propriedades da massa em bolos e sonhos, o volume, a meia-vida e a estabilidade ao congelamento de pães e bolos (Chiang \& Johnson,1977).

Chiang \& Johnson (1977) investigaram alguns fatores importantes que afetam a gelatinização do amido durante a extrusão da farinha de trigo, como a umidade da matéria-prima, a temperatura de extrusão, a velocidade do parafuso e o tamanho da matriz. A interação temperatura e umidade afetou significativamente a gelatinização do amido. $\mathrm{O}$ aumento da temperatura de extrusão aumentou a gelatinização do amido em teores de umidade entre 18 e $27 \%$. A umidade não afetou significativamente a gelatinização do amido sob baixas temperaturas $\left(65^{\circ}\right.$ e $\left.80^{\circ} \mathrm{C}\right)$, mas afetou a gelatinização em altas temperaturas $\left(95^{\circ}\right.$ e $\left.110^{\circ} \mathrm{C}\right)$. $\mathrm{O}$ aumento da velocidade do parafuso diminuiu a gelatinização do amido. Os resultados mostraram que ligações glicosídicas $(2 \rightarrow 1)$ da sacarose e da rafinose e ligações glicosídicas $(1 \rightarrow 4)$ de malto-oligosacarídeos e de amidos são quebradas quando produtos de cereais são extrusados. Durante o processo de extrusão da farinha de trigo foi observado um aumento significativo dos teores de frutose, glicose, melobiose, maltose, maltotriose e maltotetrose, sugerindo que polissacarídeos foram degradados.

A viscosidade de pasta do amido, avaliada em viscoamilógrafo, parece ser determinada por dois fatores: o grau de inchamento dos grânulos e a resistência desses grânulos à dissolução pelo calor ou a fragmentação pela agitação mecânica (Franco et al., 2001).

A viscosidade inicial das farinhas cruas é praticamente nula. Ao realizar tratamento térmico por extrusão, o amido gelatiniza, absorve água a frio e, quanto maior 
o grau de gelatinização, maior será a capacidade de formar uma pasta, gel ou líquido viscoso à temperatura ambiente (El-Dash et al., 1983). O valor da viscosidade inicial se eleva com a prévia gelatinização da amostra e decresce quando os grânulos de amido se rompem e são despolimerizados durante a cocção (Newport Scientific, 1998).

O pico de viscosidade após o início do aquecimento e antes do início do resfriamento é um parâmetro que mede a resistência do grânulo de amido ao colapso resultante da ação da temperatura e do atrito mecânico. Durante o ciclo de aquecimento até $95^{\circ} \mathrm{C}$, ocorre o intumescimento e gelatinização dos grânulos de amido, atingindo o pico máximo nesta etapa. No processo de extrusão, dependendo das condições, o tratamento térmico pode destruir a estrutura cristalina do amido, de tal forma que, no ciclo de aquecimento, o viscoamilograma apresenta ausência de pico e valores muito baixos de viscosidade. Porém, se os tratamentos não são tão severos, determinada porcentagem de grânulos de amido pode conservar parte da estrutura amilácea. Nessa condição, observam-se valores relativamente altos de viscosidade de pasta durante o aquecimento, pois há maior número de grânulos em condição de intumescimento (Carvalho et al., 2002).

A viscosidade final é a medida da retrogradação do amido que, em produtos extrusados, vai depender das modificações que ocorrem nas estruturas do grânulo e das moléculas (El-Dash, 1982). O fenômeno retrogradação é, basicamente, uma recristalização decorrente do agrupamento das moléculas de amilose e amilopectina do amido através da formação de novas pontes de hidrogênio, resultando na formação de precipitados e géis pouco solúveis (Mercier \& Feilet, 1975). O efeito dessa retrogradação implica no aumento da viscosidade da pasta a $50^{\circ} \mathrm{C}$ (Carvalho et al., 2002).

Bhattacharya et al. (1999) analisaram o efeito das variáveis de extrusão no comportamento da pasta de produtos extrusados utilizando o Rapid Visco Analyser (RVA). Estudos realizados para determinar o efeito da umidade inicial das misturas de farinha de trigo e batata sobre os produtos extrusados, mostraram que a viscosidade inicial (VI) a $30^{\circ} \mathrm{C}$ aumentou consideravelmente quando a umidade aumentou de $15,5 \%$ para $20,7 \%$. Este comportamento foi eminente quando a velocidade do parafuso foi mantida baixa (200 rpm). Segundo os autores, a baixa umidade na alimentação 
possivelmente tenha aumentado os danos pela fricção, particularmente quando o tempo de residência foi alto, devido à baixa velocidade do parafuso. $\mathrm{O}$ aumento na velocidade do parafuso aumentou os valores VI, mas de modo não significativo. Altos valores de VI foram obtidos somente com um aumento no nível de umidade do alimento para 20,7\%, antes da extrusão. Já no resfriamento, os autores não observaram um aumento acentuado na viscosidade aparente das amostras extrusadas, o que revelou que o amido já foi suficientemente gelatinizado e degradado durante a extrusão, resultando em um aumento insignificante na viscosidade final (VF) a $50^{\circ} \mathrm{C}$. Os valores de VF geralmente aumentaram com o aumento do teor de umidade dos alimentos. Os valores de quebra de viscosidade foram baixos quando os teores de umidade também foram baixos $(15,5 \%)$. O aumento da umidade elevou os valores de quebra de viscosidade. Acredita-se que a alta umidade nos alimentos pode agir como um lubrificante e reduzir a viscosidade de fundimento durante a extrusão levando a elevadas intensidades de quebra de viscosidade.

Carvalho et al. (2002) observaram que a umidade foi a variável de maior influência na extrusão de misturas de farinhas de trigo, arroz e banana embora a temperatura do processo tenha afetado a viscosidade inicial. Os valores de temperatura utilizados pelos autores variaram de 60 a $80^{\circ} \mathrm{C}$ e os de umidade foram de 30 a $40 \%$, sob rotação de $100 \mathrm{rpm}$. No experimento, os autores observaram que a alta umidade implicou em aumento da viscosidade de pasta a $95^{\circ} \mathrm{C}$ (V95). Sob baixas umidades (27 a 30\%) e em temperaturas acima de $80^{\circ} \mathrm{C}$ ocorreu decréscimo da V95. Segundo os autores, isso ocorre porque a alta temperatura torna a massa plástica menos viscosa, permitindo assim, que as moléculas tornem-se mais suscetíveis à ação de cisalhamento. Dessa forma, tem-se uma maior degradação do amido e, conseqüentemente, menores valores de viscosidade a $95^{\circ} \mathrm{C}$.

As propriedades de pasta dos extrusados assumem grande importância, quando as misturas secas pré-gelatinizadas por extrusão são utilizadas em alimentos para espessamentos (Bhattacharya et al., 1999).

As alterações no índice de solubilidade em água (ISA) e índice de absorção de água (IAA) em produtos extrusados podem ser interpretadas com base nas interações 
amido-água, que governam a estrutura da fase sólida no processamento de amiláceos (Carvalho et al., 2002).

O ISA está relacionado à quantidade de sólidos solúveis em uma amostra seca, permitindo verificar o grau de severidade do tratamento, em função da degradação, gelatinização, dextrinização e conseqüente solubilização do amido (Carvalho et al., 2002).

$\mathrm{O}$ aumento da solubilidade verificado em produtos extrusados é atribuído à dispersão das moléculas de amilose e amilopectina em conseqüência da gelatinização, quando as condições são mais brandas, e da formação de compostos de baixo peso molecular, quando estas são mais drásticas (Colonna et al., 1984).

O IAA está relacionado com a viscosidade da pasta a frio, porque somente os grânulos de amido danificados absorvem água a temperatura ambiente e incham, resultando em incremento da viscosidade. Depois de os grânulos de amido alcançarem um máximo de absorção, o IAA decresce com o começo da dextrinização (Linko et al., 1980).

De acordo com Faubion \& Hoseney (1982) o índice de absorção de água depende da disponibilidade de grupos hidrofílicos $(-\mathrm{OH})$ em se ligarem às moléculas de água e da capacidade de formação de gel das moléculas.

Hashimoto \& Grossman (2003) analisaram o efeito da extrusão em farelo e amido de mandioca. $\mathrm{O}$ aumento da temperatura de extrusão de 150 para $180^{\circ} \mathrm{C}$ diminuiu o IAA dos produtos resultantes, provavelmente devido a um aumento da degradação do amido. O aumento no IAA foi observado quando a temperatura aumentou de 180 para $210^{\circ} \mathrm{C}$. Isto pode ter sido causado por modificações estruturais de componentes das fibras. Provavelmente houve formação de uma maior abertura na estrutura seguida de penetração e retenção de água. Do mesmo modo, o IAA primeiramente diminuiu e então, elevou-se quando a velocidade do parafuso aumentou de 120 a $150 \mathrm{rpm}$ e de 150 a 180 rpm. A redução no IAA sugere que houve alguma degradação do amido, e além disso, as altas condições de cisalhamento, provavelmente, provocaram modificações estruturais nas fibras. Neste estudo o aumento do cisalhamento (120 a $180 \mathrm{rpm}$ ) aumentou o ISA. A degradação do amido e/ou fibra foi suficiente para aumentar a solubilidade. 
Chang et al. (2001) observaram em misturas de amido de mandioca e concentrados de proteínas de soja que o aumento do IAA dos extrusados foi obtido com o aumento da umidade de 20 a $26 \%$.

Carvalho et al. (2002) estudaram misturas de farinhas de trigo, arroz e banana extrusadas sob condições de teores de umidade que variaram de 30 a $40 \%$, temperatura de extrusão de 60 a $80^{\circ} \mathrm{C}$ e rotação mantida a $100 \mathrm{rpm}$. Observaram que em altas temperaturas houve um aumento no ISA. Já em teores de umidade altos, o ISA dos extrusados diminuiu. Desse modo, a combinação de baixos teores de umidade e altas temperaturas resultou numa maior degradação dos grânulos de amido, contribuindo assim, para o aumento do valor de ISA. Foi verificado portanto, que a severidade do tratamento influencia grandemente o ISA, provocando degradação, gelatinização, dextrinização e solubilização do amido.

O IAA e o ISA são parâmetros importantes para definir a aplicações de extrusados como ingredientes. Elevados valores de ISA estão também relacionados à adesividade dos produtos extrusados (Hashimoto \& Grossman, 2003).

A alta pressão existente próxima à descarga da matriz, que consiste de orifícios de diversos formatos, é liberada quando o produto sai do extrusor. Ocorre a evaporação instantânea da água com a redução da pressão (Harper, 1978). Estes processos (queda de pressão e evaporação da água) induzem a expansão do produto (Gibson \& Williams, 2000; Colonna et al., 1987). A rápida queda da umidade do produto na matriz resulta em resfriamento adiabático, com o produto alcançando uma temperatura de aproximadamente $80^{\circ} \mathrm{C}$ em questão de segundos, ocorrendo sua solidificação ou endurecimento (Harper, 1978).

Durante o processo de extrusão, o efeito de inchamento elástico e o crescimento de bolhas contribuem para as mudanças na estrutura do amido durante a expansão (Ding et al., 2005 e Thymi et al., 2005). Colonna et al. (1984) também observaram a formação de bolhas de ar em amido de trigo extrusado. Uma das razões para o crescimento de bolhas cessar é a solidificação do material, a qual ocorre na transição vítrea (Della Valle et al., 1997). A transição vítrea é caracterizada pela temperatura de transição vítrea (Sebio, 1996). 
Segundo Harmann \& Harper (1973) há dois fatores que governam a expansão: a viscosidade da massa e a força elástica no extrusor. Segundo autores, a força elástica será dominante em baixas temperaturas e baixas umidades. O crescimento de bolhas é governada pela diferença de pressão entre o interior da bolha e a pressão atmosférica.

Com base nos resultados obtidos em experimento com amido de milho, Della Valle et al. (1997) propõem dois mecanismos de expansão. Quando o produto sai da matriz, o esfriamento ocorre por causa da evaporação da água. A temperatura do produto e a umidade diminuem, portanto, a temperatura de transição vítrea $\left(\mathrm{T}_{\mathrm{g}}\right)$ aumenta. Quando a temperatura do produto é maior que a $T_{g}$, o crescimento de bolhas cessa e o extrusado adquire sua textura.

Segundo Thomas \& Atwell (1997) há dois tipos de processos de expansão: o indireto e o direto. Os alimentos expandidos indiretamente são produzidos por extrusores de parafuso único. Os extrusados apresentam baixa umidade e são estáveis durante o armazenamento. São conhecidos como half-products e antes de serem consumidos devem passar por cozimento e/ou fritura. Os produtos expandidos diretamente são feitos com extrusora de parafuso duplo, onde vários produtos diferentes podem ser produzidos com uma mesma máquina. A mistura neste extrusor também expande facilmente na saída deste como resultado da rápida perda de vapor e súbita redução da pressão.

Chang \& El-Dash (2003) observaram em amido de mandioca extrusado que a umidade (16 a 24\%), seguida da temperatura $\left(120\right.$ a $\left.200^{\circ} \mathrm{C}\right)$ afetaram significativamente a expansão do produto. Em geral, sob baixos valores de umidade, o aumento da temperatura resultou em aumento de expansão. Alta umidade e temperatura reduziram a expansão. Segundo os autores, a expansão está relacionada ao grau de gelatinização do amido. Baixos conteúdos de umidade do amido podem restringir o fluxo do material dentro do extrusor, aumentando o cisalhamento e o tempo de residência, o qual poderia talvez aumentar o grau de gelatinização.

A formação de cor durante o processo de extrusão proporciona importante informação a respeito do grau do tratamento térmico. A estabilidade da cor é uma das características de qualidade para alimentos extrusados que são normalmente consumidos diretamente sem tratamento térmico posterior (Sebio, 1996). 
Gutkoski \& El-Dash (1999) estudando produtos extrusados de aveia, sob valores de umidade do material variando de 17 a 24\%, temperatura do extrusor variando de 90 a $150^{\circ} \mathrm{C}$ e rotação da rosca que foi mantida a $100 \mathrm{rpm}$., verificaram que a luminosidade $\left(\mathrm{L}^{*}\right)$ diminuiu linearmente com o aumento da umidade inicial. Quando a temperatura de extrusão aumentou, a luminosidade diminuiu. Os componentes a* e b* comportaram-se diferentemente do componente $\mathrm{L}^{*}$. Altos valores de $\mathrm{a}^{*}$ (vermelho) e $\mathrm{b}^{*}$ (amarelo) foram obtidos com altos níveis de umidade e temperatura média $\left(120^{\circ} \mathrm{C}\right)$. Baixos valores de $\mathrm{a}^{*}$ (verde) e b* (azul) foram obtidos quando a umidade foi baixa. 


\section{MATERIAL E MÉTODOS}

\subsection{Material}

\subsubsection{Matéria-prima}

As raízes de batata-doce (Ipomoea batatas) foram adquiridas diretamente do produtor para garantir a uniformidade das amostras. Foi utilizada apenas uma cultivar, de polpa branca, colhida em novembro de 2003, aos 12 meses.

\subsubsection{Enzimas}

Foram utilizadas as enzimas amiloglucosidase de Rhizopus mold, da Sigma (A7255), a alfa-amilase termoestável (Termamyl 120L), da Novozymes, a pancreatina, da Sigma (P-3292) e a pepsina, da Sigma (P-7000).

\subsection{Métodos}

\subsubsection{Produção da farinha de batata doce}

A farinha de batata-doce foi obtida conforme indicado no fluxograma da Figura 2. Uma quantidade de $150 \mathrm{~kg}$ de batata-doce foi processada para a obtenção de aproximadamente $33 \mathrm{~kg}$ de farinha de batata-doce.

O descascamento foi manual utilizando-se de facas de aço inoxidável, eliminando-se a periderme. Após, as raízes foram imersas em solução de bissulfito de sódio a $0,5 \%$, para inibir ação enzimática. O corte foi executado por meio de triturador da marca Hobart e os pedaços ou chips obtidos foram também imersos em solução de $0,5 \%$ de bissulfito de sódio durante 10 minutos para branqueamento. A desidratação a $40^{\circ} \mathrm{C}$ foi efetuada em estufa com circulação e renovação de ar, da marca Marconi, durante 12 
horas. O material desidratado foi triturado em moinho de facas, da marca Marconi, e acondicionados em embalagens plásticas de polietileno para posterior extrusão.

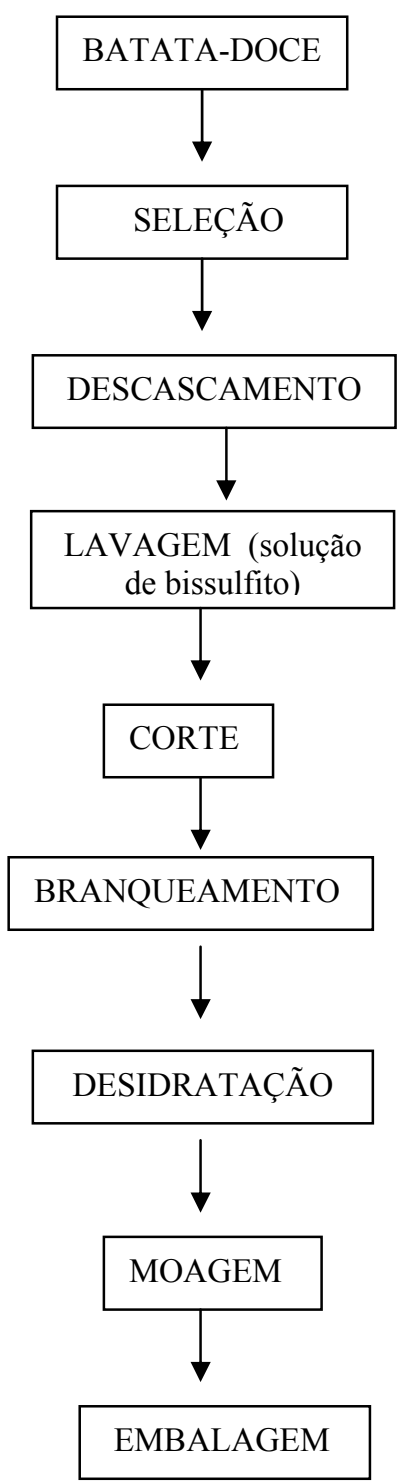

Figura 2 - Fluxograma de obtenção da farinha de batata-doce 


\subsubsection{O processo de extrusão}

A extrusão foi efetuada em uma linha completa IMBRA RX, da Imbramaq (Figura 3), com motor de 10HP acoplado a redutor de velocidade, sistema de extrusão por fricção mecânica, rosca simples, sistema de refrigeração hidráulica para controle de temperatura na camisa de extrusão, velocidade variável e capacidade de produção de $45 \mathrm{~kg} / \mathrm{h}$.

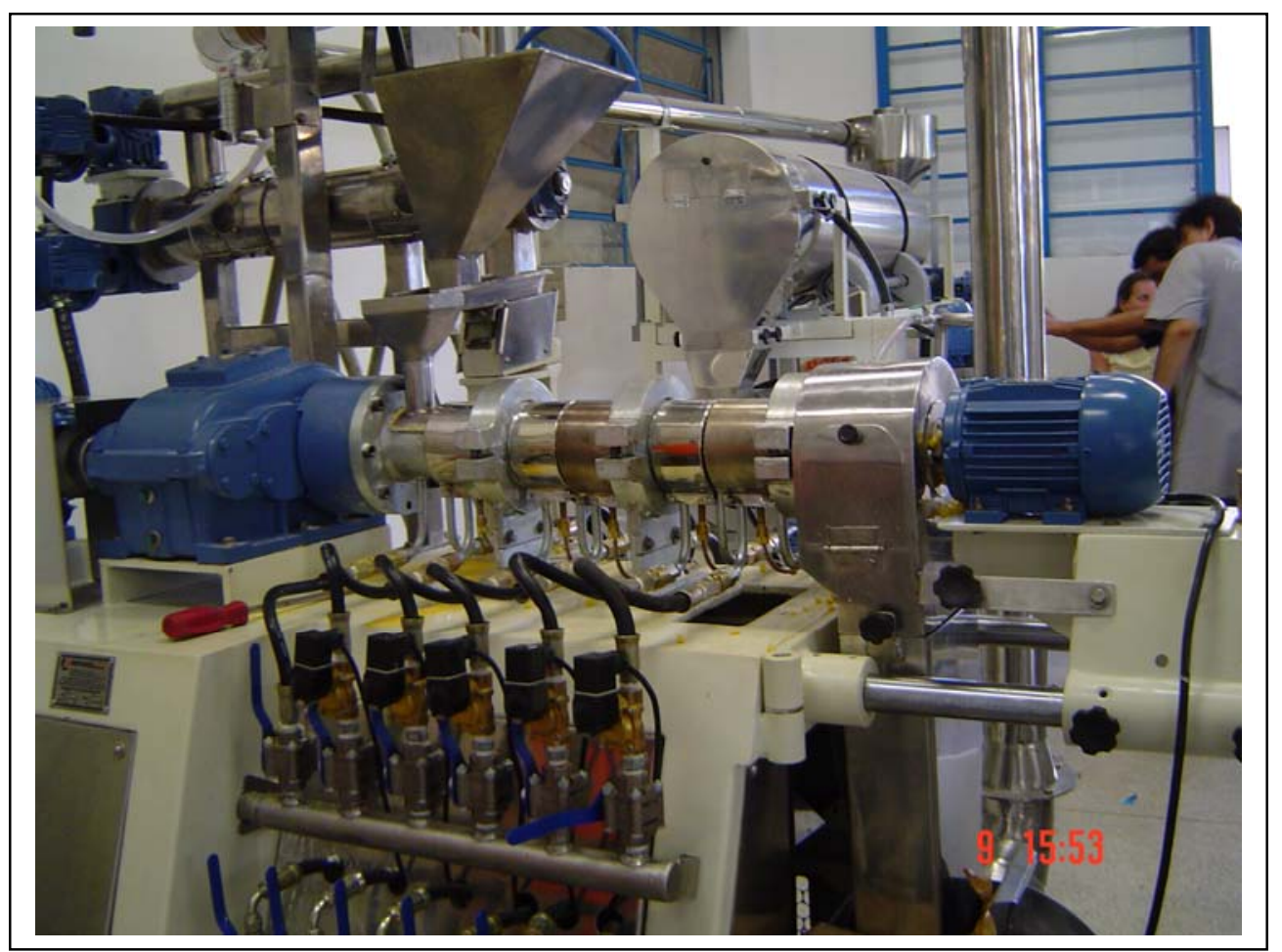

Figura 3 - Extrusor IMBRA RX utilizado para a extrusão da farinha de batata-doce

Dentre os parâmetros do extrusor, alguns foram mantidos fixos e apenas três parâmetros foram variáveis (umidade da farinha, temperatura na última zona e rotação da rosca do extrusor). Os parâmetros foram os seguintes:

- $\quad$ Parâmetros Fixos: temperatura de extrusão na $1^{\mathrm{a}}\left(20^{\circ} \mathrm{C}\right)$ e na $2^{\mathrm{a}}$ zona $\left(60^{\circ} \mathrm{C}\right)$; largura da rosca $(14 \mathrm{~mm})$; profundidade da rosca $(4,5 \mathrm{~mm})$; abertura da matriz $(5 \mathrm{~mm})$; 
taxa de compressão da rosca (1:3); taxa de alimentação (200 g/min) e velocidade de corte $(25 \%)$.

- $\quad$ Parâmetros Variáveis: umidade da farinha não extrusada (15, 18 e 21\%); temperatura de extrusão na $3^{\circ}$ zona $\left(100,120\right.$ e $\left.140^{\circ} \mathrm{C}\right)$ e rotação da rosca $(180,210$ e 240rpm).

\subsubsection{Obtenção da farinha de batata-doce extrusada}

A farinha de batata-doce não extrusada foi primeiramente acondicionada quanto aos diferentes níveis de umidade no misturador da marca Lieme, conforme o delineamento experimental. A umidificação foi realizada com água destilada esborrifada sobre a farinha que se encontrava em contínuo revolvimento. As amostras homogeneizadas foram acondicionadas em sacos plásticos e armazenadas durante 12 horas para se obter um equilíbrio. A umidade foi conferida antes do processamento através da balança de umidade infravermelho Top Ray.

A extrusão de cada amostra somente foi iniciada após as três zonas (alimentação, transição e de alta pressão) atingirem as temperaturas desejadas. Houve um descarte do produto gerado inicialmente, sendo apenas aproveitado o material coletado após o processo atingir o equilíbrio. Ao final do processamento os produtos extrusados na forma de snacks foram submetidos às determinações de taxa de expansão e, em seguida, colocados em estufa a $40^{\circ} \mathrm{C}$ por 12 horas. Após secagem, a dureza dos extrusados foi avaliada. O produto foi triturado em moinhos de facas da marca Marconi e peneirado em peneira Produtest, de malha de 60 meshes $(0,250 \mathrm{~mm})$. A farinha de batatadoce pré-gelatinizada obtida foi armazenada em frascos de vidros (snap-cap) para análises posteriores.

\subsubsection{Caracterização das farinhas de batata-doce}

A farinha de batata-doce natural (antes de ser extrusada) foi caracterizada quanto ao aspecto geral, composição físico-química, granulometria, cor, índice de 
absorção de água (IAA), índice de solubilidade em água (ISA) e propriedades viscoamilográficas.

As farinhas de batata-doce extrusadas foram avaliadas quanto: aspecto geral cor, índice de absorção de água, índice de solubilidade em água, propriedades viscoamilográficas e grau de gelatinização.

\subsubsection{Microscopia eletrônica de varredura (MEV)}

$\mathrm{O}$ aspecto geral das farinha de batata-doce extrusadas e não extrusada foi avaliado ao microscópio eletrônico de varredura (MEV), da marca Zeiss DSM 940A. A montagem das amostras foi feita em suportes (stubs) com fita adesiva dupla face, onde a farinha foi fixada e coberta com uma fina camada de ouro em metalizador Balzers.

\subsubsection{Composição físico-química}

\subsection{Umidade}

O teor de umidade da farinha de batata-doce foi determinado em estufa com circulação de ar a $105^{\circ} \mathrm{C}$, segundo o método AOAC (1995).

\subsection{Proteína bruta}

O teor de proteína da farinha foi calculada através da determinação do teor de nitrogênio pelo método micro-Kjedahl (AOAC, 1995), usando o fator 6,25 para conversão.

\subsection{Lipídeos}

O teor de lipídeos foi determinado por extração contínua com hexano em aparelho Soxhlet, segundo metodologia da AOAC (1995).

\subsection{Cinza}

O conteúdo de cinzas foi determinado após incineração da amostra em mufla a $550^{\circ} \mathrm{C}$ por 2 horas, segundo o método da AOAC (1995). 


\subsection{Fibras}

Os teores de fibras solúveis e insolúveis foram determinados pelo método enzímico de Asp et al. (1983).

\subsection{Amido}

O teor de amido foi determinado pela hidrólise enzimática de acordo com Rickard \& Behn (1987) e o teor de açúcares redutores foi dosado segundo Somogy \& Nelson (Somogy, 1945).

\subsection{Amilose}

O teor de amilose foi determinado segundo metodologia ISO 6647 (International Organization for Standardization, 1987).

\subsubsection{8 pH}

$\mathrm{O} \mathrm{pH}$ foi determinado usando o método descrito pelas normas analíticas do Instituto Adolfo Lutz (IAL, 1985).

\subsubsection{Granulometria}

A granulometria da farinha de batata-doce não extrusada foi determinada utilizando um jogo de peneiras da marca Produtest. As peneiras foram previamente taradas e $500 \mathrm{~g}$ da amostra foram colocadas. Foram levadas ao agitador por 15 minutos na velocidade máxima. Após este período, as peneiras foram pesadas e a porcentagem retida em cada uma delas foi calculada.

\subsubsection{Cor}

A cor das farinhas extrusadas e não extrusadas foi avaliada em colorímetro Minolta Chroma Meter CR 200b. Os resultados foram expressos em valores $L^{*}, a^{*}$ e b* (Bible \& Singha, 1993), onde os valores de $L^{*}$ (luminosidade ou brilho) variam do preto (0) ao branco (100), os valores do croma a* variam do verde (-60) ao vermelho $(+60) \mathrm{e}$ os valores do croma $b^{*}$ variam do azul ao amarelo, ou seja, de -60 a +60 , 
respectivamente. Os resultados obtidos foram também apresentados em termos de diferença de cor (DCO). Para tal, foi utilizada a Fórmula 1:

$\mathrm{DCO}=\left[\Delta \mathrm{L}^{2}+\Delta \mathrm{a}^{2}+\Delta \mathrm{b}^{2}\right]^{1 / 2}$

onde:

$\Delta \mathrm{L}=\mathrm{L}_{\mathrm{o}}$ (luminosidade da farinha natural) $-\mathrm{L}_{\mathrm{e}}$ (luminosidade da farinha extrusada)

$\Delta \mathrm{a}=\mathrm{a}_{\mathrm{o}}$ (valor de $\mathrm{a}^{*}$ da farinha natural) - $\mathrm{a}_{\mathrm{e}}$ (valor de $\mathrm{a}^{*}$ da farinha extrusada )

$\Delta b=b_{o}$ (valor de $b^{*}$ da farinha natural) - be (valor de $b^{*}$ da farinha extrusada)

\subsubsection{5 Índice de absorção de água (IAA)}

O IAA foi determinado segundo metodologia de Anderson et al. (1969). Em um tubo de centrífuga previamente tarado, foram colocados aproximadamente $2,5 \mathrm{~g}$ de amostra e $30 \mathrm{~mL}$ de água. Os tubos foram agitados por 30 minutos em agitador mecânico e, em seguida, centrifugados a 3000 rpm por 10 minutos, em centrífuga Excelsa Baby II, da marca FANEM, modelo 206-R. O líquido sobrenadante foi escorrido cuidadosamente em cadinho de porcelana previamente tarado. O material remanescente foi pesado e o IAA calculado conforme a Fórmula 2:

$\mathrm{IAA}=\mathrm{PRC} / \mathrm{PA}-\mathrm{PRE}$

onde:

$\mathrm{PRC}=$ peso de resíduo de centrifugação $(\mathrm{g})$

$\mathrm{PA}=$ peso da amostra $(\mathrm{g})$ (base seca)

$\mathrm{PRE}=$ peso do resíduo de evaporação $(\mathrm{g})$

\subsubsection{6 Índice de Solubilidade em Água ( ISA )}

O ISA, determinado segundo metodologia de Anderson et al. (1969), foi calculado pela relação entre o peso do resíduo de evaporação e o peso seco da amostra, conforme a Fórmula 3:

$\% \mathrm{ISA}=\mathrm{PRE} / \mathrm{PA} \times 100$ 
onde:

$\mathrm{PA}=$ peso da amostra $(\mathrm{g})$ (base seca)

$\mathrm{PRE}=$ peso do resíduo de evaporação $(\mathrm{g})$

\subsubsection{Propriedades viscoamilográficas}

Para avaliação das propriedades de pasta das farinhas de batata-doce não extrusadas e extrusadas foi utilizado o Rapid Visco Analyser (RVA), série 4, da Newport Scientific, na concentração de $3,5 \mathrm{~g}$ de farinha/ $25 \mathrm{~mL}$ de água destilada, corrigida para a base de 14\% de umidade (Newport Scientific, 1998). Devido a formação de grumos nas farinhas extrusadas, adicionou-se $1 \mathrm{~g}$ de etanol a amostra.

Foi utilizada a programação Extrusion 1 (sem álcool) para a farinha não extrusada e Extrusion 2 (com álcool) para as farinhas extrusadas, do software Thermocline for Windows, versão 2.2. As programações utilizadas estão apresentadas na Tabela 1. A viscosidade foi expressa nas unidades do aparelho, ou seja, Rapid Visco Units (RVU).

Tabela 1. Programa de extrusão, programação Extrusion 1 (sem álcool) e Extrusion 2 (com álcool)

\begin{tabular}{cccc}
\hline TEMPO & TIPO & Extrusion 1 & Extrusion 2 \\
VALOR & VALOR \\
\hline 00:00:00 & Temperatura & $25^{\circ} \mathrm{C}$ & $25^{\circ} \mathrm{C}$ \\
00:00:00 & Velocidade de rotação & $960 \mathrm{rpm}$ & $960 \mathrm{rpm}$ \\
00:00:10 & Velocidade de rotação & $160 \mathrm{rpm}$ & $160 \mathrm{rpm}$ \\
00:02:00 & Temperatura & $25^{\circ} \mathrm{C}$ & $25^{\circ} \mathrm{C}$ \\
00:07:00 & Temperatura & $95^{\circ} \mathrm{C}$ & $90^{\circ} \mathrm{C}$ \\
00:10:00 & Temperatura & $95^{\circ} \mathrm{C}$ & $90^{\circ} \mathrm{C}$ \\
$00: 15: 00$ & Temperatura & $25^{\circ} \mathrm{C}$ & $25^{\circ} \mathrm{C}$ \\
\hline
\end{tabular}

Os parâmetros avaliados, mostrados na Figura 4, foram: viscosidade inicial (VI), que é o pico de viscosidade entre o tempo 0,2 - 2 min., pico de viscosidade (PV), que é a 
viscosidade máxima obtida após o início do aquecimento e antes do início do resfriamento, quebra de viscosidade $(\mathrm{QV})$, que é a diferença entre a viscosidade máxima e mínima durante a manutenção a $95^{\circ} \mathrm{C}$ (hold), tendência a retrogradação (TR), que é a diferença entre a viscosidade final e o menor valor de viscosidade durante a manutenção a $95^{\circ} \mathrm{C}$ (hold) e viscosidade final (VF).

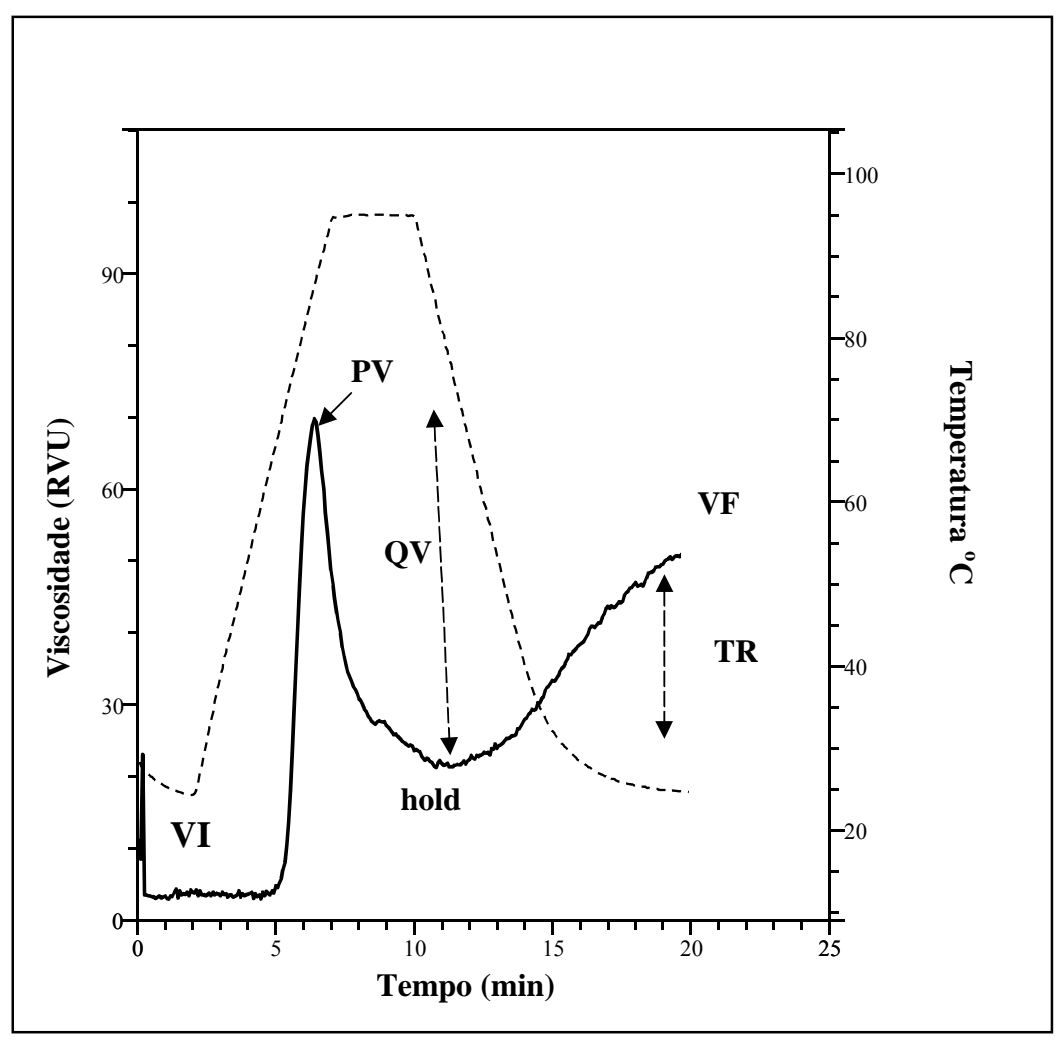

Figura 4 - Parâmetros avaliados na curva amilográfica das farinhas de batata-doce não extrusada e extrusadas

\subsubsection{Grau de gelatinização (GG)}

O grau de gelatinização foi determinado nas farinhas extrusadas de acordo com a metodologia de digestibilidade enzimática de Rickard \& Behn (1987), com modificações. Em um bequer foi colocado 0,2 g de amostra, $42 \mathrm{~mL}$ de água destilada, 2,5mL de tampão acetato ( 4 mols/L, pH 4,8) e 10 mL de solução de amiloglucosidase de 
Rhizopus mold $(1 \mathrm{~g} / 100 \mathrm{~mL})$ e colocado para agitação durante $30 \mathrm{~min}$. à $55^{\circ} \mathrm{C}$. Após este período, foi adicionado $1 \mathrm{~mL}$ de álcool etílico (para inativação enzimática). A solução foi filtrada e transferida para balão volumétrico de $250 \mathrm{~mL}$ e completado o volume. Para dosagem dos açúcares foi usado o método DNS (Miller, 1959).

A curva de calibração foi determinada através de misturas de farinha de batata doce não extrusada e de farinha de batata-doce totalmente gelatinizada, simulando misturas de 0 a 100\%. Para obtenção da farinha de batata-doce totalmente gelatinizada, utilizou-se cerca de $50 \mathrm{~g}$ de farinha não extrusada. Esta foi colocada em um béquer com 1 $\mathrm{L}$ de água destilada $(5 \% \mathrm{p} / \mathrm{p})$ e o material foi autoclavado por $1 \mathrm{~h} / 120^{\circ} \mathrm{C}$. Após este período, o material foi liofilizado e triturado em moinhos de facas da marca Marconi. O grau de gelatinização (\%) foi diretamente obtido da curva de calibração, que apresentou coeficiente de correlação de 0,99 .

\subsubsection{Características físicas dos extrusados}

Os extrusados de farinha de batata-doce foram avaliados quanto ao índice de expansão e dureza:

\subsubsection{1 Índice de expansão (IE)}

O IE foi avaliado no material após a extrusão e antes da secagem. Calculado pela relação entre o diâmetro da amostra e o diâmetro da matriz, conforme a metodologia proposta por Faubion \& Hoseney (1982). O valor considerado foi obtido pela média aritmética das medidas de 10 diferentes extrusados dentro de cada tratamento.

\subsubsection{Dureza}

A dureza ou resistência à ruptura dos extrusados foi determinada no material desidratado utilizando o texturômetro Texture Test System, série 2053, modelo TP1, acoplado a um registrador automático de variação de força. $\mathrm{O}$ instrumento operou com os sensores eletrônicos de 300 libras-forças (lbf). A pressão utilizada foi de $20 \mathrm{~kg}$ força e a velocidade de descida do cabeçote foi de $30 \mathrm{~cm} / \mathrm{min}$. As amostras foram posicionadas 
horizontalmente na plataforma e uma faca de aço retangular (Single Blade Shear Cell) foi utilizada para romper a amostra. O valor considerado foi a média aritmética das determinações de força de quebra de 10 extrusados por amostra e expresso em lbf/g.

\subsubsection{Delineamento experimental}

Antes da definição dos valores utilizados no experimento final foram realizados pré-testes com a farinha de batata-doce natural variando os teores de umidade, temperatura e rotação de parafuso, para definir a melhor faixa de variação. Para se definir estes valores foram considerados os resultados obtidos para índice de solubilidade em água, índice de absorção de água e análise de viscosidade pelo RVA, ou seja, maiores valores de viscosidade inicial e de absorção de água e menores valores de solubilidade em água.

Para analisar o efeito combinado das variáveis independentes ou preditoras nas características dos extrusados, optou-se pela metodologia de superfície de resposta do tipo central composto rotacional de $2^{\mathrm{a}}$ ordem (Box et al., 1978). Os parâmetros do processo estabelecidos como variáveis independentes foram estudados em 3 níveis codificados como $-1,0$ e +1 , calculados de acordo com a equação 1 :

$\mathrm{x}_{\mathrm{i}}=\mathrm{X}_{\mathrm{i}}-\mathrm{Z} / \Delta \mathrm{X}_{\mathrm{i}}$

onde:

$\mathrm{X}_{\mathrm{i}}=$ valor codificado da variável $\mathrm{X}_{\mathrm{i}}$

$\mathrm{X}_{\mathrm{i}}=$ valor real da variável

$\mathrm{Z}=$ valor real da variável no ponto central

$\Delta \mathrm{X}_{\mathrm{i}}=$ valor do intervalo de variação de $\mathrm{x}_{\mathrm{i}}$ 
Este delineamento apresenta também 2 níveis de variáveis axiais que são codificados como $-\alpha \mathrm{e}+\alpha$. $\mathrm{O}$ valor depende do número fatorial $\left(\mathrm{F}=2^{\mathrm{k}}\right)$ do delineamento e do número de variáveis independentes $(\mathrm{k}=3)$ sendo o valor definido pela equação 2 :

$\alpha=(\mathrm{F}) \frac{1 / 4}{4}=\left(2^{\mathrm{k}}\right) \frac{1 / 4}{4}=1,681$

Os valores máximos e mínimos de cada variável independente (ou preditora) foram estabelecidos dentro das possibilidades operacionais do processo de extrusão e com base em diversos ensaios preliminares. Para análise de resultados experimentais, a metodologia descreve o comportamento de um sistema no qual estão combinadas as variáveis independentes $\left(\mathrm{X}_{\mathrm{k}}\right)$ e a variável dependente (ou resposta) $\mathrm{Y}_{\mathrm{i}}$. A resposta é uma função dos níveis nos quais estes fatores foram combinados e definidos como segue:

$$
\mathrm{Y}_{\mathrm{i}}=\mathrm{F}\left(\mathrm{X}_{1}, \mathrm{X}_{2}, \ldots \ldots, \mathrm{X}_{\mathrm{k}}\right)
$$

Através de uma análise de regressão, pode-se ajustar para cada resposta (Y) um polinômio de segunda ordem com as variáveis explicativas $\left(\mathrm{X}_{\mathrm{k}}\right)$. A expressão geral utilizada para predizer o comportamento de cada resposta avaliada pode ser escrita pela equação 3:

$Y_{i}=\beta_{0}+\beta_{1} X_{1}+\beta_{2} X_{2}+\beta_{3} X_{3}+\beta_{11} X_{1}^{2}+\beta_{22} X_{2}^{2}+\beta_{33} X_{3}^{2}+\beta_{12} X_{1} X_{2}+\beta_{13} X_{1} X_{3}+\beta_{23} X_{2} X_{3}$

onde:

$\mathrm{Y}_{\mathrm{i}}=$ função resposta;

$\mathrm{X}_{1}, \mathrm{X}_{2}, \mathrm{X}_{3}=$ valores das variáveis independentes;

$\beta_{1}, \beta_{2}, \beta_{3}=$ coeficiente lineares estimados pelo método dos quadrados mínimos;

$\beta_{11}, \beta_{22}, \beta_{33}=$ coeficientes das variáveis quadráticas;

$\beta_{12}, \beta_{13}, \beta_{23}=$ coeficiente de interação entre as variáveis independentes. 
$\mathrm{O}$ processamento dos dados e a análise estatística foram realizadas com o auxílio do RSREG do sistema SAS versão 8.2 (SAS, 1999). A significância do modelo foi testada pela análise de variância (ANOVA). Foi adotado o nível de significância alfa de $10 \%(\alpha=0,10)$.

O experimento foi conduzido num delineamento fatorial incompleto $3^{3}$ (Box \& Beheken, 1960) com três fatores ou variáveis independentes (temperatura, umidade, rotação da rosca) e três níveis codificados. Tanto os níveis codificados quanto os axiais e os fatores têm seus valores reais mostrados na Tabela 2 .

Tabela 2. Os níveis codificados e axiais e seus valores reais utilizados no experimento

\begin{tabular}{ccccc}
\hline & Níveis & \multicolumn{3}{l}{ Fatores ou variáveis independentes } \\
\hline Axiais & codificados & X1 & X2 & X3 \\
$-\alpha$ & & 13 & 86 & 160 \\
& -1 & 15 & 100 & 180 \\
& 0 & 18 & 120 & 210 \\
& +1 & 21 & 140 & 240 \\
$+\alpha$ & & 23 & 154 & 260 \\
\hline
\end{tabular}

Onde:

$\mathrm{X} 1=$ Umidade das amostras $(\%)$

$\mathrm{X} 2=$ Temperatura do processo $\left({ }^{\circ} \mathrm{C}\right)$

$\mathrm{X} 3=$ Velocidade do parafuso $(\mathrm{rpm})$

O delineamento experimental empregado no processo de extrusão da farinha de batata-doce, incluindo os valores codificados e reais das variáveis independentes são apresentados na Tabela 3. 
Tabela 3. Delineamento experimental do processo de extrusão de farinha de batata-doce

\begin{tabular}{|c|c|c|c|c|c|c|}
\hline \multirow[b]{2}{*}{ Tratamentos } & \multicolumn{2}{|c|}{ Variáveis Codificadas } & & \multicolumn{2}{|c|}{ Variáveis Independentes } & \multirow[b]{2}{*}{$\mathrm{X} 3$} \\
\hline & $\mathrm{X} 1$ & $\mathrm{X} 2$ & $\mathrm{X} 3$ & $\mathrm{X} 1$ & $\mathrm{X} 2$ & \\
\hline 1 & -1 & -1 & -1 & 15 & 100 & 180 \\
\hline 2 & 1 & -1 & -1 & 21 & 100 & 180 \\
\hline 3 & -1 & 1 & -1 & 15 & 140 & 180 \\
\hline 4 & 1 & 1 & -1 & 21 & 140 & 180 \\
\hline 5 & -1 & -1 & 1 & 15 & 100 & 240 \\
\hline 6 & 1 & -1 & 1 & 21 & 100 & 240 \\
\hline 7 & -1 & 1 & 1 & 15 & 140 & 240 \\
\hline 8 & 1 & 1 & 1 & 21 & 140 & 240 \\
\hline 9 & 0 & 0 & 0 & 18 & 120 & 210 \\
\hline 10 & 0 & 0 & 0 & 18 & 120 & 210 \\
\hline 11 & 0 & 0 & 0 & 18 & 120 & 210 \\
\hline 12 & 0 & 0 & 0 & 18 & 120 & 210 \\
\hline 13 & 0 & 0 & 0 & 18 & 120 & 210 \\
\hline 14 & 0 & 0 & 0 & 18 & 120 & 210 \\
\hline 15 & $-\alpha$ & 0 & 0 & 13 & 120 & 210 \\
\hline 16 & $+\alpha$ & 0 & 0 & 23 & 120 & 210 \\
\hline 17 & 0 & $-\alpha$ & 0 & 18 & 86 & 210 \\
\hline 18 & 0 & $+\alpha$ & 0 & 18 & 154 & 210 \\
\hline 19 & 0 & 0 & $-\alpha$ & 18 & 120 & 160 \\
\hline 20 & 0 & 0 & $+\alpha$ & 18 & 120 & 260 \\
\hline
\end{tabular}

Onde: $\mathrm{X} 1=$ Umidade das amostras $(\%) ; \mathrm{X} 2=$ Temperatura do processo $\left({ }^{\circ} \mathrm{C}\right) ; \mathrm{X} 3=$ Velocidade do parafuso (rpm) 


\section{RESULTADOS E DISCUSSÃO}

\subsection{Caracterização da farinha de batata-doce não extrusada}

\subsubsection{Aspecto geral}

O aspecto geral da farinha de batata-doce não extrusada e de seus grânulos de amido foi avaliado por microscopia eletrônica de varredura (MEV). As fotos produzidas são apresentadas na Figura 5.
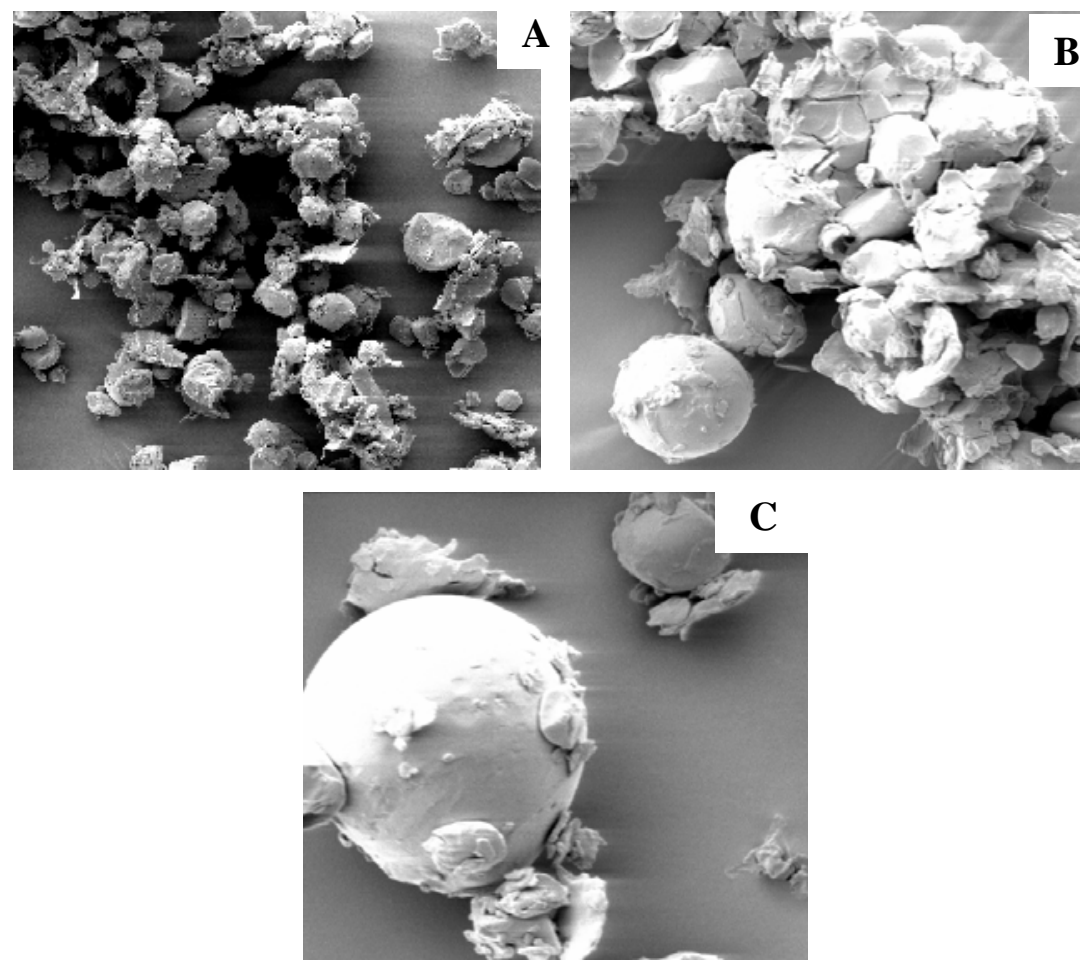

Figura 5 - Aspecto da farinha de batata-doce não extrusada. A) aumento $20 \mathrm{x}$;

B) aumento $100 \mathrm{x}$ e C) aumento $200 \mathrm{x}$ 
$\mathrm{Na}$ farinha não extrusada os componentes apresentam-se soltos ou aglomerados, porém, íntegros. Pelas fotos podem ser identificados grânulos de amido, em seus formatos originais e materiais não amiláceos, que se acham aderidos entre si ou aos grânulos de amido.

\subsubsection{Composição físico-química}

A composição físico-química da farinha de batata-doce não extrusada está apresentada na Tabela 4. Como pode se observar, a farinha de batata-doce é um alimento basicamente amiláceo, possui consideráveis teores de açúcares simples e de proteínas e baixo conteúdo de lipídeos.

Tabela 4. Composição físico-química da farinha de batata-doce

\begin{tabular}{lc}
\hline Componentes & Teores (\%) \\
\hline Umidade & 8,7 \\
Amido & 58,1 \\
Amilose & 10,5 \\
Açúcares solúveis totais & 17,0 \\
Proteínas (N x 6,25) & 6,7 \\
Lipídeos & 0,7 \\
Cinzas & 2,7 \\
Fibras insolúveis & 4,3 \\
Fibras solúveis & 1,7 \\
pH & 5,7 \\
\hline
\end{tabular}

A farinha de batata-doce apresentou teores de proteína, lipídeos e cinzas superiores aos encontrados por Iwe et al. (2004), que foram de 4,6, 0,5 e 2,3\%, respectivamente. Segundo Miranda et al. (1995) a composição química da batata-doce pode variar com a cultivar, condições climáticas, época de colheita, tratos culturais, condições e duração de armazenamento. 


\subsubsection{Granulometria}

A farinha de batata-doce apresentou granulometria variável (Tabela 5). Aproximadamente $33 \%$ do material ficou retido nas peneiras de malhas maiores (abertura de $0,300 \mathrm{~mm}$ ou maiores) e cerca $67 \%$ da farinha ficou retida nas peneiras de malhas mais finas (aberturas de $0,250 \mathrm{~mm}$ ou menores) e no fundo.

Tabela 5. Granulometria da farinha de batata-doce

\begin{tabular}{cc}
\hline Abertura da peneira $(\mathrm{mm})$ & Porcentagem retida (\%) \\
\hline 0,850 & 0,47 \\
0,600 & 5,73 \\
0,420 & 20,73 \\
0,300 & 6,36 \\
0,250 & 4,3 \\
0,210 & 1,87 \\
0,180 & 1,93 \\
0,150 & 1,56 \\
0,125 & 4,45 \\
0,088 & 6,03 \\
0,075 & 3,98 \\
0,045 & 21,63 \\
fundo & 20,63 \\
\hline
\end{tabular}

\subsubsection{Cor}

Os valores do componente $\mathrm{L}^{*}$ representam a luminosidade ou brilho das amostras. Estes valores variam de zero (preto) a 100 (branco). 
Os valores expressos no eixo a* representam a cores de verde ao vermelho, sendo que quanto mais o valor for negativo (-a*), mais próximo do verde e quanto mais positivo $\left(+\mathrm{a}^{*}\right)$ for o valor, mais próximo do vermelho.

Os valores expressos no eixo $b^{*}$ representam a cores que variam de azul ao amarelo, sendo que quanto mais o valor for negativo (-b*), mais próximo está do azul e quanto mais o valor for positivo $\left(+b^{*}\right)$, mais próximo está do amarelo.

Os parâmetros L*, a* e b* da farinha não extrusada foram 94,57, -0,47 e 7,53, respectivamente. De acordo com estes resultados, a farinha de batata-doce natural caracteriza-se por uma alta luminosidade, ou seja, é uma farinha muito clara e possui uma tendência à cor amarela.

\subsection{5 Índice de absorção de água (IAA) e índice de solubilidade em água (ISA)}

Os valores de IAA e ISA da farinha não extrusada foram $3,1 \mathrm{~g} / \mathrm{g}$ gel e $16,6 \%$, respectivamente.

\subsubsection{Viscoamilograma}

A viscosidade é uma das propriedades mais importantes dos materiais amiláceos. A curva de viscosidade representa o seu comportamento durante o aquecimento e permite avaliar as características da pasta formada, devidas às modificações estruturais das moléculas de amido e também à tendência a retrogradação durante o resfriamento. Estas características determinam as propriedades funcionais das matérias primas amiláceas e suas diversas aplicações industriais (Sebio, 1996).

A curva amilográfica da farinha de batata-doce não extrusada está apresentada na Figura 6. 


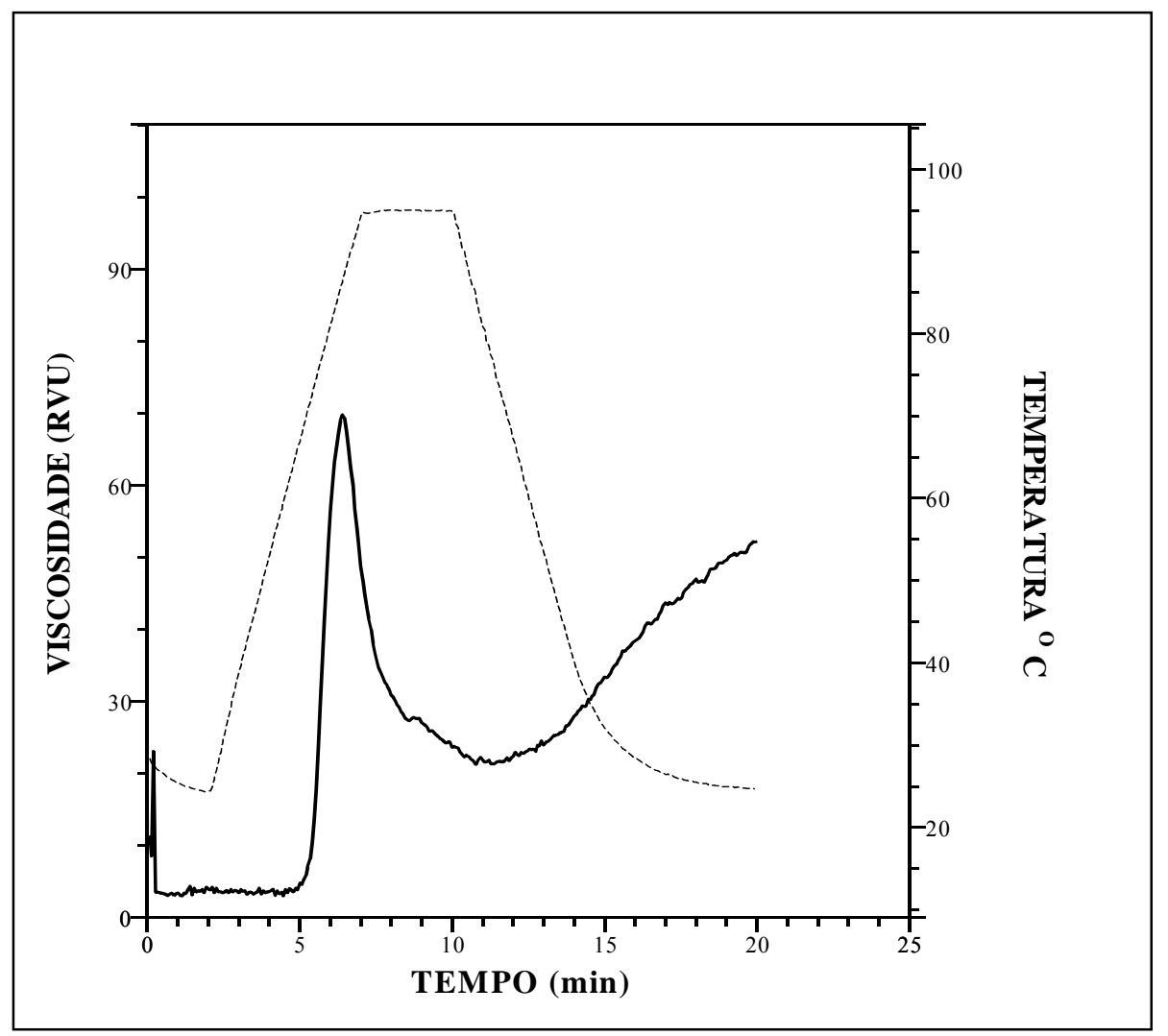

Figura 6 - Perfil da curva de viscosidade de farinha de batata-doce não extrusada

A viscosidade inicial a $25^{\circ} \mathrm{C}$ foi próxima de zero ( $\left.2 \mathrm{RVU}\right)$, conforme o esperado, devido a ausência de amido gelatinizado. O pico de viscosidade foi de 70 RVU, ocorrido na temperatura de $\pm 70^{\circ} \mathrm{C}$. Os valores obtidos de quebra de viscosidade e tendência à retrogradação foram 49 e 31 RVU, respectivamente. Após atingir o pico, a viscosidade decresce mostrando quebra intensa de viscosidade em temperatura elevada $\left(95^{\circ} \mathrm{C}\right)$, sob agitação. Com o abaixamento da temperatura (de 95 para $25^{\circ} \mathrm{C}$ ) a viscosidade aumenta devido à tendência do amido à retrogradação, atingindo o valor de viscosidade final de 52RVU. 


\subsection{Características tecnológicas dos extrusados}

\subsubsection{Aspecto geral}

A Figura 7 ilustra os extrusados obtidos da farinha de batata-doce nas diferentes condições experimentais.

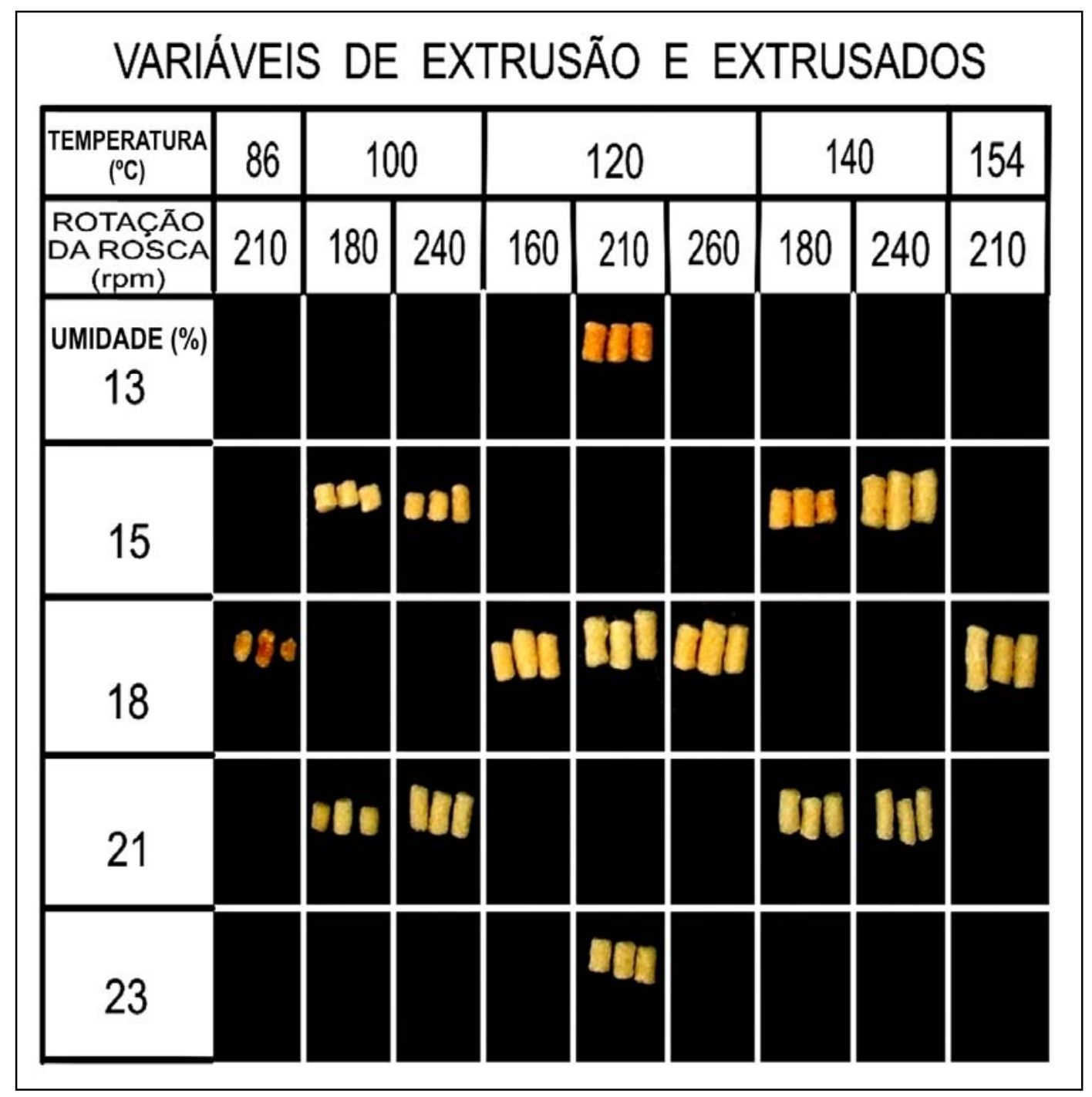

Figura 7 - Aparência dos extrusados nas diferentes condições do processo

Observa-se que as dimensões dos extrusados variam com as condições de processo empregadas. Desse modo, é possível produzir extrusados com diferentes graus de expansão variando as condições da extrusão. 


\subsection{2 Índice de expansão e dureza}

A Tabela 6 mostra o efeito das variáveis independentes (umidade, temperatura e rotação de rosca) sobre as propriedades dos extrusados. Os extrusados foram avaliados antes da secagem quanto ao índice de expansão (IE) e após a secagem quanto à dureza (DUR).

Tabela 6. Índice de expansão e dureza dos extrusados dentro de cada tratamento de extrusão

\begin{tabular}{cccccc}
\hline Tratamentos & \multicolumn{3}{c}{ Variáveis independentes } & \multicolumn{2}{c}{ Variáveis dependentes } \\
\hline 1 & X1 & X2 & X3 & IE & DUR \\
2 & 15 & 100 & 180 & 2,34 & 35,5 \\
3 & 21 & 100 & 180 & 2,17 & 48,3 \\
4 & 15 & 140 & 180 & 2,52 & 54,0 \\
5 & 21 & 140 & 180 & 2,15 & 57,5 \\
6 & 15 & 100 & 240 & 2,27 & 39,3 \\
7 & 21 & 100 & 240 & 2,18 & 42,1 \\
8 & 15 & 140 & 240 & 2,6 & 48,2 \\
9 & 21 & 140 & 240 & 1,85 & 41,0 \\
10 & 18 & 120 & 210 & 2,28 & 51,2 \\
11 & 18 & 120 & 210 & 2,42 & 59,6 \\
12 & 18 & 120 & 210 & 2,36 & 50,3 \\
13 & 18 & 120 & 210 & 2,11 & 41,0 \\
14 & 18 & 120 & 210 & 2,16 & 59,0 \\
15 & 18 & 120 & 210 & 2,37 & 50,2 \\
16 & 13 & 120 & 210 & 2,48 & 52,9 \\
17 & 18 & 120 & 210 & 2,17 & 43,3 \\
18 & 18 & 86 & 210 & 1,87 & 39,1 \\
19 & 18 & 120 & 160 & 2,31 & 46,4 \\
20 & 18 & 120 & 260 & 2,42 & 53,0 \\
\hline
\end{tabular}

Onde:

$\mathrm{X} 1=$ umidade $(\%) ; \mathrm{X} 2=$ temperatura do extrusor $\left({ }^{\circ} \mathrm{C}\right) ; \mathrm{X} 3=$ rotação da rosca $(\mathrm{rpm}) ; \mathrm{IE}=$ índice de expansão; DUR = dureza $(\mathrm{lbf} / \mathrm{g})$ 


\subsubsection{1 Índice de expansão}

A expansão do material ocorre na saída do extrusor devido à diferença de temperatura e pressão interna e externa. Com o superaquecimento do produto ocorre uma rápida evaporação da água na saída da matriz e a formação de células de ar (Sebio, 1996).

A equação do modelo total ajustado de $2^{\mathrm{a}}$ ordem para índice de expansão dos extrusados está descrito na equação 4 .

$I E=-3,93+0,201 U+0,080 T-0,0018 R+0,0015 U^{2}-0,000157 T^{2}+0,0000312 R^{2}$

$-0,00179 \mathrm{UT}-0,000417 \mathrm{UR}-0,000033 \mathrm{TR} \quad\left({ }^{5 \%} \mathrm{R}^{2}: 73,58 \%\right)$

Onde: $\mathrm{U}=$ umidade; $\mathrm{T}=$ temperatura; $\mathrm{R}=$ rotação

A análise de variância (ANOVA) do modelo total ajustado para índice de expansão dos extrusados está apresentada na Tabela 7.

Tabela 7. Análise de variância dos fatores e regressão para o índice de expansão dos extrusados

\begin{tabular}{lccccc}
\hline Causa da variação & GL & SQ & F & Pr > F & $\mathrm{R}^{2}$ \\
\hline Umidade & 4 & 0,371 & 4,98 & 0,0181 & 0,093 \\
Temperatura & 4 & 0,221 & 2,97 & 0,074 & 0,055 \\
Rotação & 4 & 0,026 & 0,35 & 0,837 & 0,0065 \\
Regressão & 9 & 0,52 & 3,09 & 0,0465 & 0,736 \\
Resíduos & 10 & 0,187 & - & - & 0,019 \\
\hline
\end{tabular}

O modelo de regressão adotado para a variação deste parâmetro foi significativo $(\mathrm{p}<0,05)$. Dentre os fatores que compõem o modelo, a umidade $(\mathrm{p}=0,0181)$ e a temperatura $(\mathrm{p}=0,074)$ afetaram significativamente o IE, ao passo que não foi observado o efeito significativo $(p>0,10)$ do fator rotação de rosca. $O$ coeficiente de correlação 
múltipla $\left(\mathrm{R}^{2}\right)$ foi de 73,6 \% indicando um bom ajuste do modelo aos dados, o que garante a validade das predições efetuadas.

O IE dos extrusados variou de 1,85 a 2,60. A Figura 8 mostra o efeito da umidade da mistura e da temperatura do extrusor no índice de expansão quando a rotação do extrusor foi mantida no ponto central (210 rpm). Foi observado que em baixa umidade, o IE aumentou com a elevação da temperatura. Os menores valores de IE foram obtidos principalmente com baixa umidade e baixa temperatura, mas também alta umidade e alta temperatura.

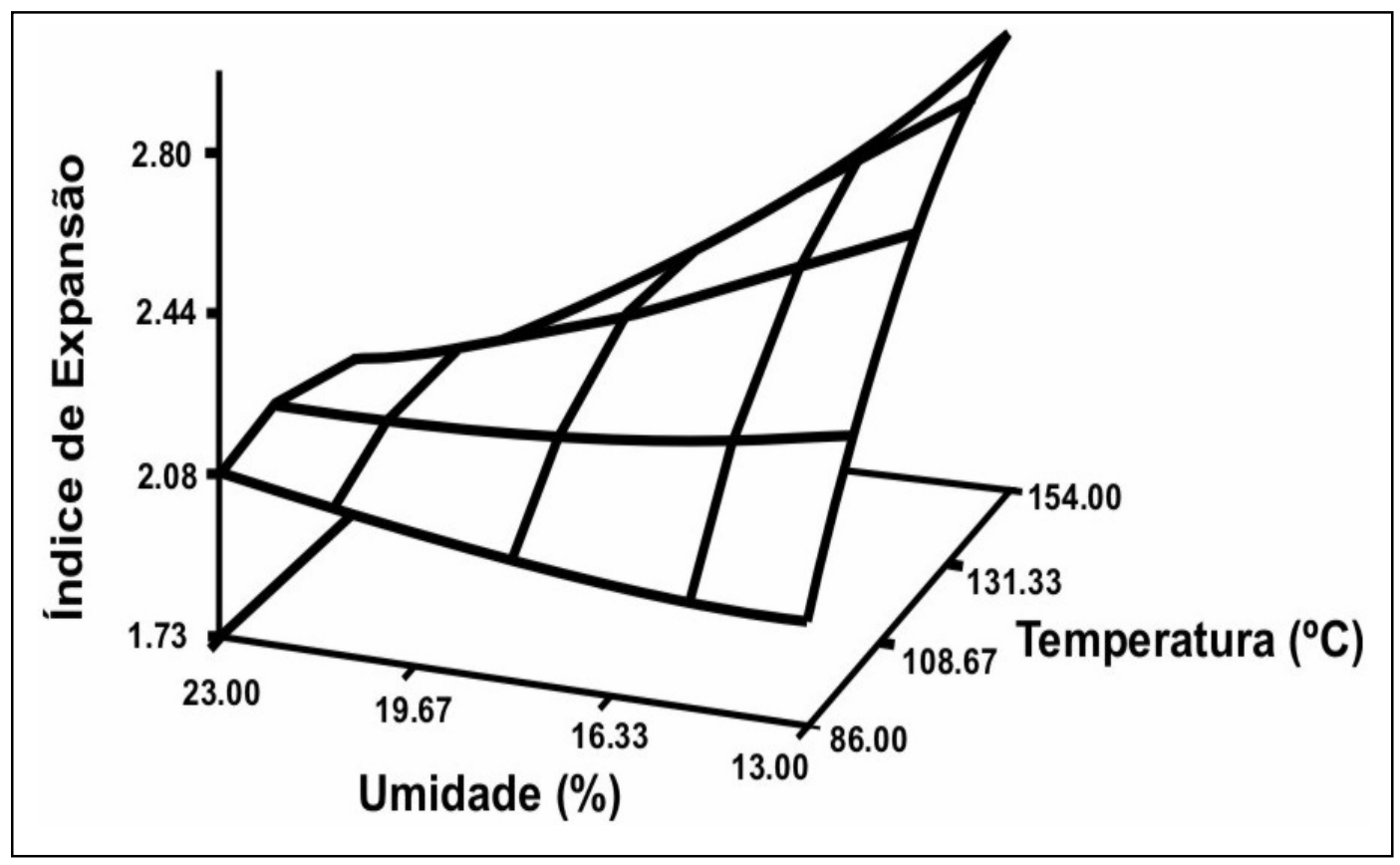

Figura 8 - Efeito da umidade das amostras e da temperatura de extrusão no índice de expansão dos extrusados de batata-doce, sob rotação de 210 rpm

Sebio (1996) encontrou resultados semelhantes aos deste trabalho para farinha de inhame. Segundo o autor, a umidade e a temperatura tiveram efeitos evidentes na propriedade de expansão do extrusado, que variou de 1,2 a 2,6. Os maiores valores de expansão foram obtidos em temperaturas altas e umidades baixas. Quando em altas umidades e temperaturas, os extrusados de inhame apresentaram menores valores de 
expansão, sendo que as condições de processamento variaram de 18 a 26\% de umidade, 100 a $150^{\circ} \mathrm{C}$ de temperatura e 100 a $200 \mathrm{rpm}$ de rotação de rosca.

Chang \& El-Dash (2003) encontraram resultados semelhantes em extrusados de amido de mandioca. Com a rotação constante a 100 rpm, a umidade (16 a 24\%), seguida da temperatura $\left(120\right.$ a $\left.200^{\circ} \mathrm{C}\right)$ afetaram significativamente a expansão do produto. No geral, sob baixos valores de umidade, o aumento da temperatura resultou em aumento de expansão. Alta umidade e alta temperatura diminuíram a expansão. Segundo os autores, a expansão está relacionada ao grau de gelatinização do amido. Baixos conteúdos de umidade no material podem restringir o fluxo do mesmo dentro do extrusor, aumentando o cisalhamento e o tempo de residência, o que poderia talvez aumentar o grau de gelatinização.

Alves \& Grossman (2002) verificaram que a expansão de snacks de cará também aumentou quando se trabalhou valores mais baixos de umidade, porém em temperaturas de extrusão mais baixas. Neste caso, os níveis de umidade e de temperatura de extrusão utilizados foram 16 a $24 \%$ e 120 a $180^{\circ} \mathrm{C}$, respectivamente, e a rotação foi constante a $150 \mathrm{rpm}$.

Chang et al. (2001) encontraram o máximo de expansão em extrusados de amido de mandioca e concentrado protéico de soja, quando a umidade do produto, que variou de 20 a $26 \%$, foi baixa. A temperatura utilizada variou de 120 a $160^{\circ} \mathrm{C}$ e a rotação foi mantida constante a $250 \mathrm{rpm}$.

A expansão de materiais amiláceos é inversamente proporcional à umidade do material a ser extrusado (Arêas, 1996). Segundo Ding et al. (2005) a água tem efeito inverso sobre a expansão agindo como um plastificante para materiais amiláceos, reduzindo sua viscosidade e a dissipação da energia mecânica no extrusor e assim o produto fica mais denso e o crescimento de bolhas é comprimido. O aumento da quantidade de água durante a extrusão poderia mudar a estrutura molecular da amilopectina do material, reduzindo a viscosidade elástica, diminuindo assim a expansão (Ding et al., 2005 e Thymi et al., 2005). 
No entanto, foram encontrados na literatura resultados que contradizem os anteriormente citados com respeito ao efeito da umidade do material e da temperatura do extrusor sobre o índice de expansão.

Iwe \& Ngoddy (1998) observaram em misturas de farinha de batata-doce e de soja extrusadas, que a expansão aumentou com a elevação da umidade e atribuíram o fato à facilidade do fundimento para expansão ou ao aumento na pressão do vapor, provavelmente devido a baixa rotação de rosca que foi mantida a $80 \mathrm{rpm}$. Os valores de umidade testados pelos autores variaram de 18 a $30 \%$ e a temperatura foi mantida a $100^{\circ} \mathrm{C}$.

Hashimoto \& Grossmann (2003) observaram em mistura de amido e farelo de mandioca, que o aumento da temperatura do extrusor, que variou de 150 a $210^{\circ} \mathrm{C}$, resultou em menor expansão dos extrusados. A umidade variou de 16 a $20 \%$ e a rotação da rosca variou de 120 a $180 \mathrm{rpm}$. Segundo autores, a elevação da temperatura pode ocasionar o evaporação violenta da água, causando a quebra da estrutura e assim, dificultando a expansão.

\subsubsection{Dureza (DUR)}

A dureza (resistência à ruptura) é uma propriedade dos extrusados onde a transição vítrea é de suma importância. Neste tipo de material o aumento rápido da mobilidade molecular, em nível da temperatura de transição vítrea, provoca uma modificação rápida na crocância do produto (Attenburrow et al., 1993). Segundo Alves \& Grossman (2002) a dureza é um dos fatores que determina a aceitabilidade de extrusados pelo consumidor e é desejável que seus valores sejam baixos.

A equação do modelo total ajustado de $2^{\mathrm{a}}$ ordem para dureza (DUR) dos extrusados (desidratados) de batata-doce está expresso na equação 5.

$$
\begin{aligned}
& \text { DUR }=-474,47+18,19 U+3,13 T+1,58 R-0,21 U^{2}-0,0055 T^{2}-0,0014 R^{2}-0,040 U T \\
& -0,0287 U R-0,00415 T R\left({ }^{p>10 \%} R^{2}: 58,7 \%\right)
\end{aligned}
$$


Onde: $\mathrm{U}=$ umidade; $\mathrm{T}=$ temperatura; $\mathrm{R}=$ rotação

A análise de variância (ANOVA) do modelo total ajustado para dureza dos extrusados está apresentada na Tabela 8 .

Tabela 8. Análise de Variância dos fatores e regressão para DUR dos extrusados

\begin{tabular}{lccccc}
\hline Causa da variação & GL & SQ & F & Pr > F & $\mathrm{R}^{2}$ \\
\hline Umidade & 4 & 149,71 & 0,94 & 0,48 & 37,428 \\
Temperatura & 4 & 446,41 & 2,81 & 0,08 & 111,602 \\
Rotação & 4 & 139,93 & 0,88 & 0,50 & 34,981 \\
Regressão & 9 & 564,92 & 1,58 & 0,24 & 0,587 \\
Resíduos & 10 & 397,72 & - & - & 39,772 \\
\hline
\end{tabular}

Os resultados obtidos quanto ao efeito das variáveis independentes na DUR estão expressos na Tabela 6, onde se observa uma variação de 35,5 a 59,6lbf/g dentro dos tratamentos utilizados no presente estudo. Entretanto, o modelo de regressão adotado não foi significativo $(\mathrm{p}>0,10)$ para este parâmetro. O coeficiente de correlação múltipla $\left(\mathrm{R}^{2}\right)$ foi de $58,7 \%$, indicando falta de ajuste do modelo aos dados.

No geral, foi observado que a dureza se mostrou menos acentuada quando a umidade e temperatura encontravam-se em seus valores mais baixos. Já em temperaturas mais altas, a DUR dos extrusados foi maior. Nos altos valores de rotação (menor tempo de residência) a DUR se manteve baixa.

Sebio (1996) extrusou farinha de inhame, com a umidade variando de 18 a $26 \%$, a temperatura do extrusor de 100 a $150^{\circ} \mathrm{C}$ e a rotação de rosca de 100 a $200 \mathrm{rpm}$. Os valores altos de DUR foram obtidos a baixas temperaturas e umidades elevadas e os menores valores de DUR foram obtidos em altas temperaturas e baixas umidades. O mesmo (menores valores de dureza em baixas umidades e altas temperaturas) também foi obtido por Alves \& Grossman (2002), para farinha de cará, com umidade variando de 16 a $24 \%$, temperatura do extrusor de 120 a $180^{\circ} \mathrm{C}$ e a rotação de rosca mantida a $150 \mathrm{rpm}$. 
Ding et al. (2005) extrusaram farinha de arroz para obtenção de snacks, sob valores de umidade que variaram de 14 a $22 \%$, temperatura de 100 a $140^{\circ} \mathrm{C}$ e rotação de rosca de 180 a $320 \mathrm{rpm}$. Observaram que a elevação da umidade aumentou significativamente a dureza dos extrusados.

Sebio (1996) atribuiu a menor resistência à ruptura principalmente à evaporação instantânea da água superaquecida antes da solidificação da estrutura, conferindo ao produto uma característica mais porosa e expandida. Já a maior resistência à ruptura o autor atribuiu à baixa pressão interna no extrusor e, conseqüentemente, à uma lenta evaporação da água do produto na saída da matriz permitindo uma solidificação da estrutura antes que ocorresse um grau adequado de expansão.

\subsection{Características tecnológicas das farinhas de batata-doce extrusadas}

$\mathrm{Na}$ Tabela 9 são apresentados os resultados do efeito das variáveis independentes (umidade, temperatura e rotação de rosca) sobre as propriedades das farinhas extrusadas de batata-doce. As farinhas extrusadas foram avaliadas quanto ao aspecto geral, cor ( $\mathrm{L}^{*}, \mathrm{a}^{*}, \mathrm{~b}^{*}$ e diferença de cor), índice de absorção de água (IAA), índice de solubilidade em água (ISA), propriedades viscográficas (viscosidade inicial, pico de viscosidade, quebra de viscosidade, tendência a retrogradação, viscosidade final) e grau de gelatinização.

\subsubsection{Aspecto geral}

Para avaliação do aspecto geral das farinhas de batata-doce extrusadas por microscopia eletrônica de varredura foram selecionados 10 tratamentos dentre os 20 realizados. Os tratamentos escolhidos foram do 1 ao 8,11 e 17. Como não foram observadas diferenças entre os tratamentos quanto ao aspecto morfológico, apenas algumas das fotos produzidas são apresentadas na Figura 9. 
Tabela 9. Características das farinhas de batata-doce extrusadas dentro de cada tratamento de extrusão

\begin{tabular}{|c|c|c|c|c|c|c|c|c|c|c|c|c|c|c|c|}
\hline \multirow[t]{2}{*}{$\mathrm{T}$} & \multicolumn{3}{|c|}{$\begin{array}{c}\text { Variáveis } \\
\text { independentes }\end{array}$} & \multicolumn{12}{|c|}{ Variáveis Dependentes } \\
\hline & $\mathrm{X} 1$ & $\mathrm{X} 2$ & $\mathrm{X} 3$ & $\mathrm{~L}^{*}$ & $a^{*}$ & $\mathrm{~b}^{*}$ & DCO & IAA & ISA & VI & PV & QV & TR & VF & $\mathrm{GG}$ \\
\hline 1 & 15 & 100 & 180 & 84,30 & 0,67 & 22,73 & 18,34 & 5,42 & 13,14 & 45,14 & 83 & 31,78 & 24,50 & 37,56 & 3 \\
\hline 2 & 21 & 100 & 180 & 3,03 & -1 & 15,07 & 10,15 & 6,19 & 17,81 & 27,97 & 29,89 & 16 & 29,39 & 2,42 & 0,87 \\
\hline 3 & 15 & 140 & 180 & 0 & 1 , & 24,63 & 20 & 6,16 & 17,34 & 39,00 & 35 & 9 & 25 & 5 & 8,79 \\
\hline 4 & 21 & 140 & 180 & 7 & -1 & 18,23 & 14 & 5,96 & 12 & 30 & & & & &, 00 \\
\hline 5 & 15 & 100 & 240 & 8 & 0 & 24 & 20 & 5,66 & 11 & & & & & & 84 \\
\hline 6 & 21 & 100 & 240 & 4,2 & & 19 & 16 & 5,34 & 12 & & 0 & & & & 18 \\
\hline 7 & 15 & 140 & 240 & 8 & & 21 & & 5,00 & 14 & & & & & & 19 \\
\hline 8 & 21 & 140 & 240 & 85, & & 17 & 14, & 5,44 & 12 & 17 & & & & & 99,70 \\
\hline 9 & 18 & 120 & 21( & 86 & & 17 & 12 & 5 , & 13 & 23 & & & & & 95,74 \\
\hline 10 & 18 & 120 & 21 & & & 19 & & 5, & 13 & & & & & & 90 \\
\hline 11 & 18 & 120 & 21 & 86 , & -1 & 16 & 12 & 5 , & 15 & & & & & & 84 \\
\hline 12 & 18 & 120 & 21 & 85,7 & 0 , & 18 & 14 & 6,01 & 22 & 25 & 27 & & 17 & & 92,39 \\
\hline 13 & 18 & 120 & 21 & 84,77 & -1 & 21 & 16 & 5, & 12 & 27,50 & 28 & & & & 89,04 \\
\hline 14 & 18 & 120 & 21 & 85,43 & -1 , & 17,90 & 13, & 5,48 & 10 & 23,34 & 24,83 & 17 & 20,21 & 27 & 89,34 \\
\hline 15 & 13 & 120 & 21 & 78 & 4, & 28,20 & 26 , & 5,83 & 13 & 44 & 44,14 & & & & 95,13 \\
\hline 16 & 23 & 120 & 21 & 86 & -1 , & 17,50 & 12 & 5,73 & 17 & 23 & 22,92 & & & & 90,56 \\
\hline 17 & 18 & 86 & 21 & 81,27 & 1, & 24,07 & 21,30 & 5,23 & 13,03 & 22,79 & & & 17,59 & 24,92 & 86,00 \\
\hline 18 & 18 & 154 & 21 & 84,80 & -0 & 22,20 & 17,32 & 5 & 12,98 & 28,21 & 25,55 & 17,21 & 23,09 & 31,42 & 90,56 \\
\hline 19 & 18 & 120 & 16 & 86,63 & -0 & 20,73 & 15 & 4,98 & 12,36 & 22,13 & 22,50 & 11,83 & 24,13 & 34,79 & 91,17 \\
\hline 20 & 18 & 120 & 260 & 83,63 & 0,37 & 21,10 & 17,49 & 5,24 & 14,57 & 26,55 & 26,88 & 18,96 & 20,05 & 27,96 & 89,65 \\
\hline
\end{tabular}

Onde: $\mathrm{T}=$ Tratamento; $\mathrm{X} 1=$ umidade $(\%) ; \mathrm{X} 2=$ temperatura do extrusor $\left({ }^{\circ} \mathrm{C}\right) ; \mathrm{X} 3=$ rotação da rosca $(\mathrm{rpm}) ; \mathrm{L}^{*}=$ Luminosidade; $\mathrm{a}^{*}=$ vermelho/verde; $\mathrm{b}^{*}=$ amarelo/azul; DCO = diferença de cor; IAA = índice de absorção de água (g/ggel); ISA = índice de solubilidade em água (\%); VI = viscosidade inicial à $25^{\circ} \mathrm{C}(\mathrm{RVU})$; $\mathrm{PV}=$ pico de viscosidade $(\mathrm{RVU}) ; \mathrm{QV}=$ quebra de viscosidade $(\mathrm{RVU}) ; \mathrm{TR}=$ tendência a retrogradação (RVU); VF = viscosidade final (RVU); GG = grau de gelatinização (\%) 

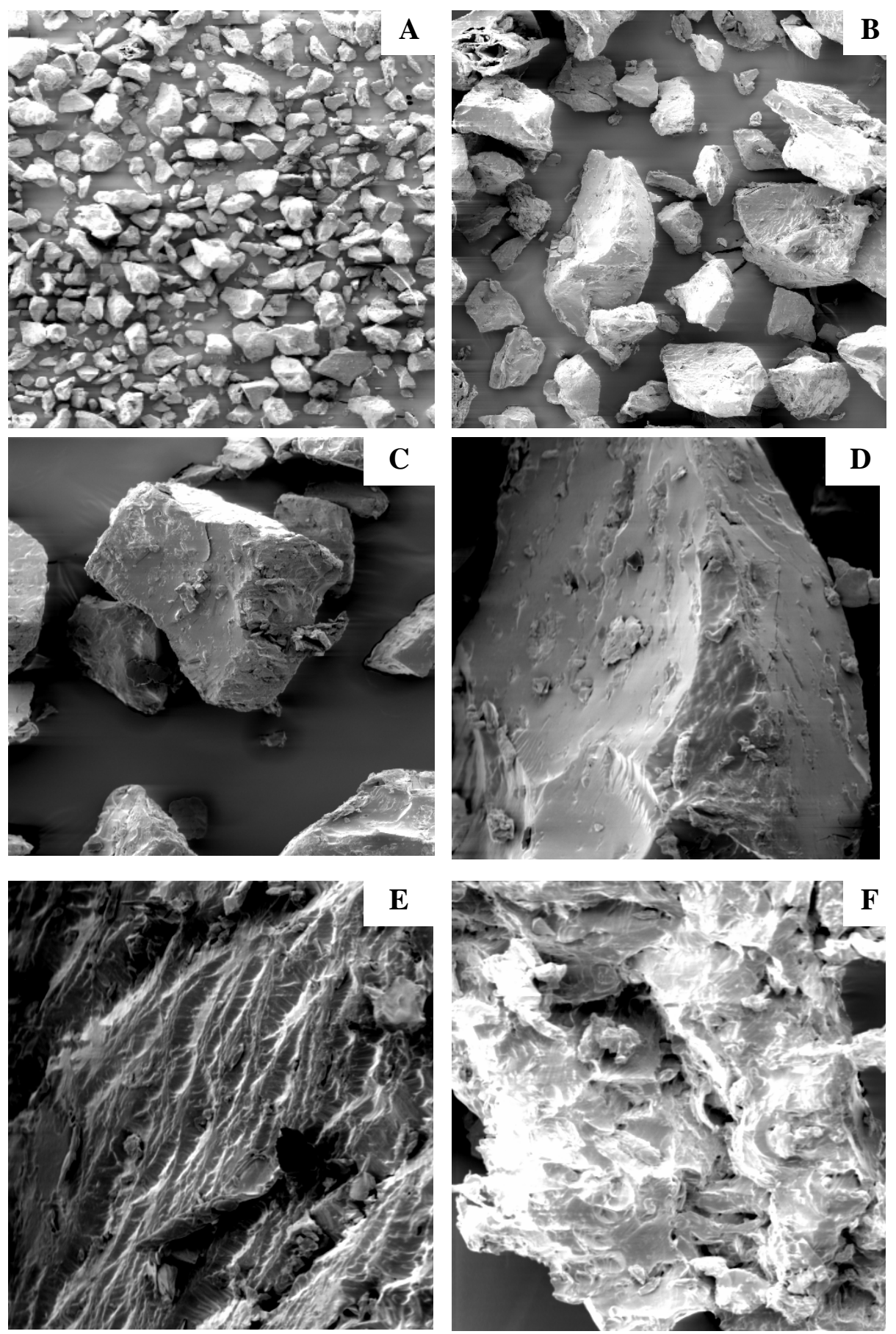

Figura 9 - Aspecto das farinhas de batata-doce extrusadas. A) aumento $20 \times(\mathrm{T} 8)$; B) aumento $100 \times$ (T8); C) aumento $200 \times$ (T5); D) aumento $500 \times$ (T8); E) aumento de $500 \times(\mathrm{T} 3)$ e F) aumento $500 \times$ (T1) 
Pela Figura 9A e 9B, observa-se que a farinha de batata-doce extrusada apresenta aspecto de uma massa compacta, amorfa, onde não é possível distinguir grânulos de amido e material não amiláceo, como na farinha de batata-doce não extrusada (Figura 5). Na Figura 9C e 9D pode ser observado que o material apresenta superfície irregular, com partes lisas, partes estriadas e alguns orifícios. Já na Figura 9E e 9F pode se observar áreas mais irregulares, com a presença de buracos, provavelmente formados pelas bolhas de ar que são geradas durante a expansão do material.

\subsubsection{Cor}

A cor adquirida pelos produtos extrusados pode ser devido à caramelização ou à reação de Maillard, principalmente em materiais que apresentam teores relativamente altos de açúcares totais. A lisina e outros aminoácidos presentes provavelmente reagem com os açúcares redutores, favorecidos pelas condições de processamento, ocorrendo escurecimento dos produtos extrusados(Gutkoski \& El-Dash, 1999).

Os componentes de cor analisados foram os valores $\mathrm{L}^{*}, \mathrm{a}^{*}$ e $\mathrm{b}^{*}$ e através destes parâmetros, foi obtido o valor da diferença de cor entre as farinhas extrusadas e não extrusada.

\subsubsection{Componente $L^{*}$}

O componente $\mathrm{L}^{*}$ das farinhas extrusadas variou de 81 a 88 , sendo que o valor de $L^{*}$ na farinha não extrusada foi de 94,6. Houve, portanto, uma redução na luminosidade das farinhas extrusadas, ou seja, escureceram.

O polinômio descrito na equação 6 corresponde ao modelo total ajustado de $2^{\mathrm{a}}$ ordem para luminosidade das farinhas extrusadas.

$$
\begin{aligned}
& L^{*}=33,614+5,470 \mathrm{U}+0,146 \mathrm{~T}-0,092 \mathrm{R}-0,090 \mathrm{U}^{2}-0,0017 \mathrm{~T}^{2}+0,000081 \mathrm{R}^{2} \\
& -0,0016 \mathrm{UT}-0,0072 \mathrm{UR}+0,00143 \mathrm{TR} \quad\left({ }^{5 \%} \mathrm{R}^{2}: 73,44 \%\right)
\end{aligned}
$$

Onde: $\mathrm{U}=$ umidade; $\mathrm{T}=$ temperatura; $\mathrm{R}=$ rotação 
A análise de variância (ANOVA) do modelo total ajustado para o componente de luminosidade das farinhas extrusadas está apresentada na Tabela 10.

Tabela 10. Análise de Variância dos fatores e regressão para o componente L* das farinhas extrusadas

\begin{tabular}{llllll}
\hline Causa da variação & GL & SQ & F & Pr $>$ F & $\mathrm{R}^{2}$ \\
\hline Umidade & 4 & 44,015 & 5,01 & 0,0177 & 11,004 \\
Temperatura & 4 & 14,216 & 1,62 & 0,245 & 3,554 \\
Rotação & 4 & 12,748 & 1,45 & 0,288 & 3,187 \\
Regressão & 9 & 60,741 & 3,07 & 0,0476 & 0,7344 \\
Resíduos & 10 & 21,972 & - & - & 2,197 \\
\hline
\end{tabular}

O modelo de regressão adotado foi significativo $(\mathrm{p}<0,05)$ para a variação deste parâmetro. Dentre os fatores que compõem o modelo, a umidade $(p=0,0177)$ afetou significativamente o componente $\mathrm{L}^{*}$, ao passo que os efeitos dos fatores temperatura e rotação da rosca de extrusão sobre a luminosidade das farinhas extrusadas não foram significativos. O coeficiente de correlação múltipla $\left(\mathrm{R}^{2}\right)$ foi de $73,4 \%$ indicando um bom ajuste do modelo aos dados, o que garante a validade das predições efetuadas.

A Figura 10 mostra o efeito da umidade das amostras sobre o componente $\mathrm{L}^{*}$ das farinhas extrusadas quando a temperatura e rotação da rosca foram mantidas no ponto central do delineamento $\left(120^{\circ} \mathrm{C}\right.$ e $\left.210 \mathrm{rpm}\right)$. Foi observado aumento do componente $\mathrm{L}^{*}$ com o aumento da umidade até $20-21 \%$. Os produtos mais claros são obtidos nestes teores de umidade. A partir deste teor houve uma redução dos valores de L*. 


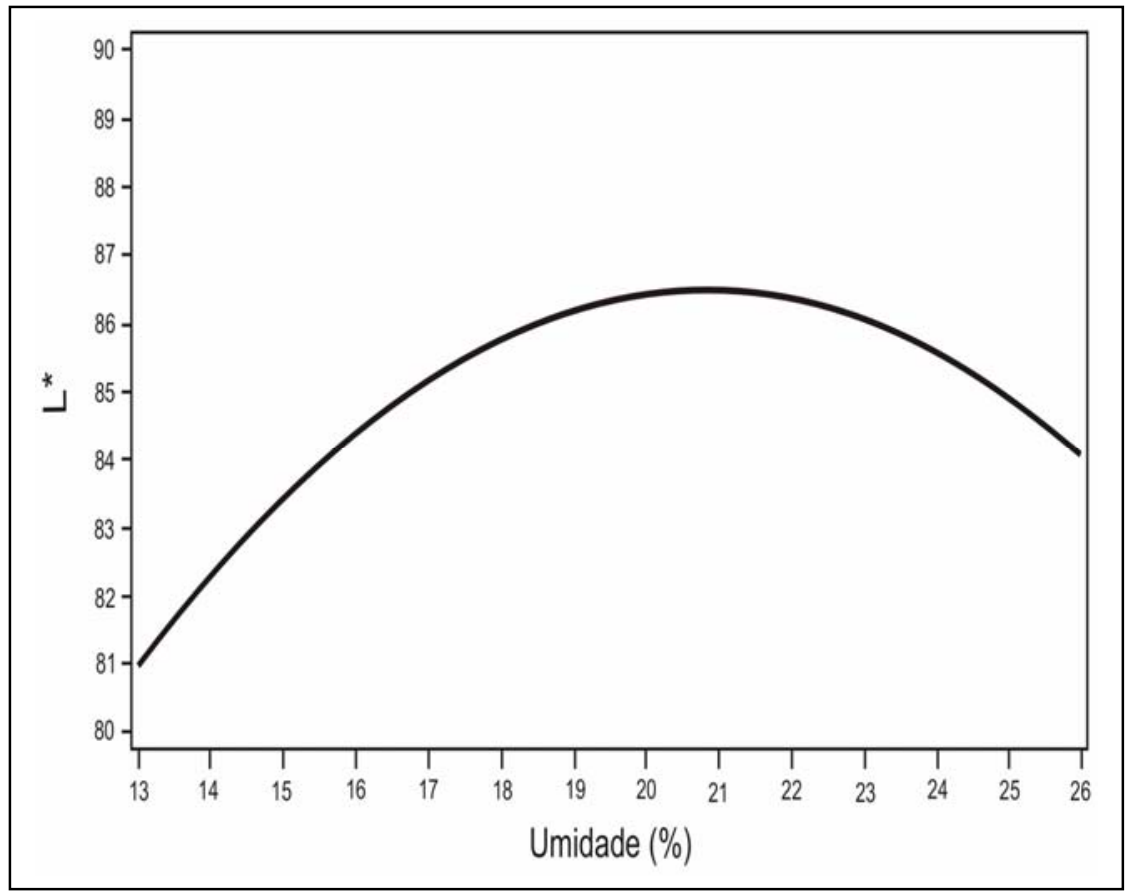

Figura 10 - Efeito do teor de umidade da matéria-prima sobre o componente $\mathrm{L}^{*}$ das farinhas extrusadas, sob condições de temperatura de $120^{\circ} \mathrm{C}$ e rotação de $210 \mathrm{rpm}$

\subsubsection{Valor de $\mathrm{a}^{*}$}

O valor de $a^{*}$ variou de 4,6 a $-1,9$, o que mostra que houve pequena variabilidade neste parâmetro durante o processo de extrusão, considerando que a variação deste parâmetro vai de $-60 \mathrm{a}+60$. A farinha de batata-doce natural apresentou o valor de $a^{*}$ de $-0,47$, mostrando que o processo aumenta a intensidade deste parâmetro no caso de algumas amostras e diminui a intensidade no caso de outras.

O polinômio descrito na equação 7 corresponde ao modelo total ajustado de $2^{\mathrm{a}}$ ordem para o parâmetro a* das farinhas extrusadas.

$$
\begin{aligned}
& a^{*}=40,752-3,695 U+0,137 T-0,116 R+0,0707 U^{2}+0,000811 T^{2}+0,000201 R^{2} \\
& -0,00852 U T+0,00838 U R-0,00095 T R\left({ }^{3 \%} R^{2}: 77,29 \%\right)
\end{aligned}
$$


Onde: $\mathrm{U}=$ umidade; $\mathrm{T}=$ temperatura e $\mathrm{R}=$ rotação

A análise de variância (ANOVA) do modelo total ajustado para valor do croma $a^{*}$ das farinhas extrusadas está apresentada na Tabela 11.

Tabela 11. Análise de Variância dos fatores e regressão para o componente a* das farinhas extrusadas

\begin{tabular}{llllll}
\hline Causa da variação & GL & SQ & F & Pr $>$ F & $\mathrm{R}^{2}$ \\
\hline Umidade & 4 & 44,015 & 5,01 & 0,018 & 11,004 \\
Temperatura & 4 & 14,216 & 1,62 & 0,245 & 3,554 \\
Rotação & 4 & 12,748 & 1,45 & 0,288 & 3,187 \\
Regressão & 9 & 39,581 & 3,78 & 0,0249 & 0,7729 \\
Resíduos & 10 & 11,630 & - & - & 1,163 \\
\hline
\end{tabular}

O modelo de regressão adotado para a variação deste parâmetro foi significativo $(p<0,03)$ nas condições experimentais. Dentre os fatores que compõem o modelo, a umidade $(\mathrm{p}=0,0056)$ afetou significativamente o parâmetro $\mathrm{a}^{*}$, ao passo que para os fatores temperatura e rotação da rosca não se observou efeito significativo sobre o croma a*. O coeficiente de correlação múltipla $\left(\mathrm{R}^{2}\right)$ foi de $77,3 \%$, indicando um ótimo ajuste do modelo aos dados, o que garante a validade das predições efetuadas.

A Figura 11 mostra o efeito da umidade sobre o parâmetro a* quando a temperatura e rotação da rosca foram mantidas no ponto central $\left(120^{\circ} \mathrm{C}\right.$ e $\left.210 \mathrm{rpm}\right)$. Com o aumento da umidade da matéria-prima (até 21-22\%) o componente a* tendeu ao negativo (verde). 


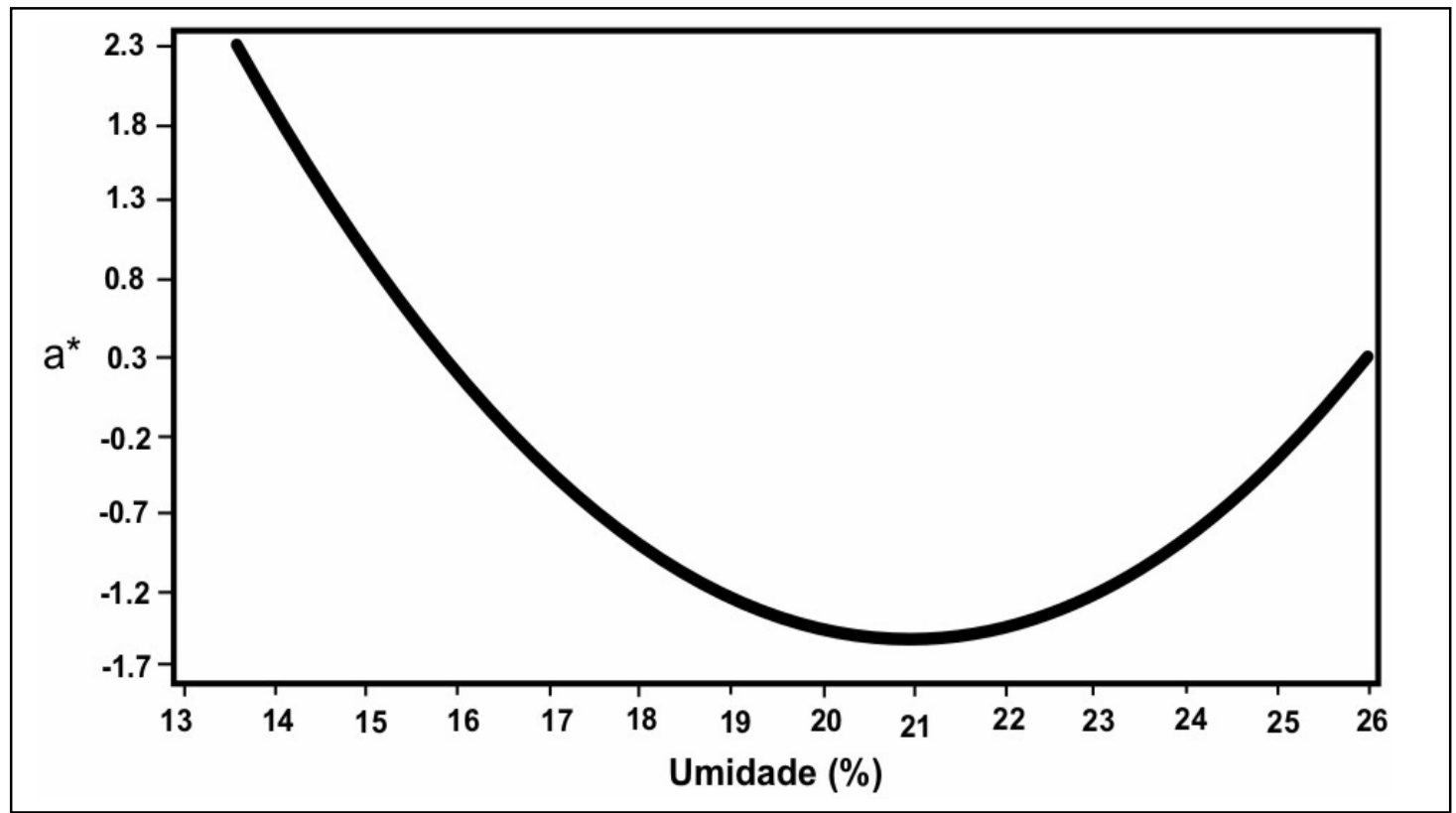

Figura 11 - Efeito do teor umidade sobre o parâmetro a* das farinhas extrusadas, sob temperatura de $120^{\circ} \mathrm{C}$ e rotação de rosca de $210 \mathrm{rpm}$

\subsubsection{Valor de $b^{*}$}

$\mathrm{O}$ valor de $\mathrm{b}^{*}$ variou de 24,7 a 17,5 , sendo que na farinha de batata-doce não extrusada o valor de $b^{*}$ foi de 7,5, ou seja, nas farinhas extrusadas o processo de extrusão causou uma elevação na intensidade do croma amarelo.

O polinômio descrito na equação 8 corresponde ao modelo total ajustado de $2^{\mathrm{a}}$ ordem para o parâmetro $b^{*}$ das farinhas extrusadas.

$$
\begin{aligned}
& \mathrm{b}^{*}=117,87-7,457 \mathrm{U}-0,324 \mathrm{~T}-0,0343 \mathrm{R}+0,119 \mathrm{U}^{2}+0,0029 \mathrm{~T}^{2}+0,00042 \mathrm{R}^{2} \\
& +0,00506 \mathrm{UT}+0,00743 \mathrm{UR}-0,00223 \mathrm{TR}\left({ }^{1 \%} \mathrm{R}^{2}: 85,69 \%\right)
\end{aligned}
$$

Onde: $\mathrm{U}=$ umidade; $\mathrm{T}=$ temperatura; $\mathrm{R}=$ rotação 
A análise de variância (ANOVA) do modelo total ajustado para o croma $b^{*}$ das farinhas extrusadas está apresentada na Tabela 12.

Tabela 12. Análise de Variância dos fatores e regressão para o componente $b^{*}$ das farinhas extrusadas

\begin{tabular}{llllll}
\hline Causa da variação & GL & SQ & F & Pr $>$ F & $\mathrm{R}^{2}$ \\
\hline Umidade & 4 & 142,053 & 12,12 & 0,0007 & 35,513 \\
Temperatura & 4 & 35,637 & 3,05 & 0,0695 & 8,909 \\
Rotação & 4 & 20,565 & 1,76 & 0,2134 & 5,141 \\
Regressão & 9 & 174,92 & 6,65 & 0,0033 & 0,8569 \\
Resíduos & 10 & 29,208 & - & - & 2,921 \\
\hline
\end{tabular}

O modelo de regressão adotado foi significativo $(\mathrm{p}<0,0033)$ para este parâmetro. Dentre os fatores que compõem o modelo, a umidade $(p=0,0007)$ e a temperatura $(\mathrm{p}=0,0695)$ afetaram significativamente o parâmetro $\mathrm{b}^{*}$, ao passo que $\mathrm{o}$ efeito do fator rotação da rosca sobre este parâmetro não foi significativo. $\mathrm{O}$ coeficiente de correlação múltipla $\left(\mathrm{R}^{2}\right)$ foi de $85,7 \%$, indicando um ótimo ajuste do modelo aos dados, o que garante a validade das predições efetuadas.

A Figura 12 mostra o efeito da umidade e temperatura no parâmetro $b^{*}$ quando a rotação da rosca foi mantida no ponto central $(210 \mathrm{rpm})$.

Com a diminuição da umidade, independentemente da temperatura, ocorre um aumento do componente $+\mathrm{b}^{*}$, ou seja, aumentou a intensidade do croma amarelo. Os valores de $b^{*}$ apresentaram-se mais baixos, em altos valores de umidade e temperaturas intermediárias. 


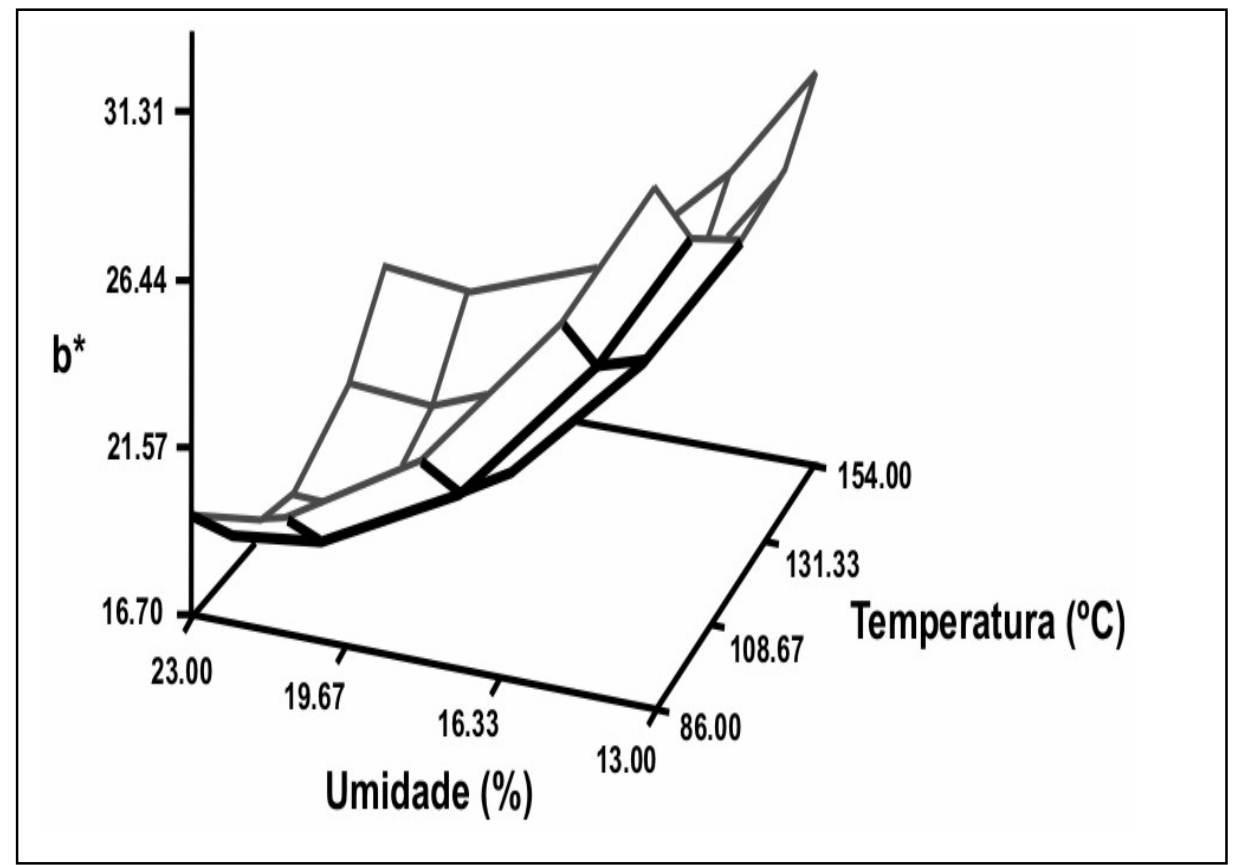

Figura 12 - Efeito do teor de umidade da matéria-prima e a temperatura do extrusor no parâmetro b* das farinhas extrusadas, sob à rotação de 210 rpm

\subsubsection{Diferença de cor (DCO)}

A DCO define a diferença de cor entre o produto extrusado e a matéria prima. Nas condições do estudo a DCO variou de 10,15 a 26,50.

A equação do modelo total ajustado de $2^{\mathrm{a}}$ ordem para diferença de cor da farinha de batata-doce extrusada está expressa na equação 9 .

$$
\begin{aligned}
& \mathrm{DCO}=137,67-9,997 \mathrm{U}-0,371 \mathrm{~T}-0,018 \mathrm{R}+0,161 \mathrm{U}^{2}+0,00321 \mathrm{~T}^{2}+0,000321 \mathrm{R}^{2} \\
& +0,00604 \mathrm{UT}+0,0113 \mathrm{UR}-0,00252 \mathrm{TR}\left({ }^{1 \%} \mathrm{R}^{2}: 83,71 \%\right)
\end{aligned}
$$

Onde: $\mathrm{U}=$ umidade; $\mathrm{T}=$ temperatura; $\mathrm{R}=$ rotação

A análise de variância (ANOVA) do modelo total ajustado para diferença de cor entre o material extrusado e não extrusado está apresentada na Tabela 13. 
Tabela 13. Análise de Variância dos fatores e regressão para diferença de cor das farinhas

\begin{tabular}{llllll}
\hline Causa da variação & GL & SQ & F & Pr $>$ F & $\mathrm{R}^{2}$ \\
\hline Umidade & 4 & 184,95 & 10,36 & 0,0014 & 46,238 \\
Temperatura & 4 & 46,57 & 2,61 & 0,0998 & 11,642 \\
Rotação & 4 & 31,64 & 1,77 & 0,2111 & 7,910 \\
Regressão & 9 & 229,42 & 5,71 & 0,0059 & 0,837 \\
Resíduos & 10 & 44,65 & - & - & 4,465 \\
\hline
\end{tabular}

O modelo de regressão adotado para este parâmetro foi significativo $(\mathrm{p}<0,006)$. Dentre os fatores que compõem o modelo, a umidade $(p=0,0014)$ e a temperatura $(p=$ 0,10) afetaram significativamente a cor, ao passo que a rotação da rosca não afetou significativamente este parâmetro. $\mathrm{O}$ coeficiente de correlação múltipla $\left(\mathrm{R}^{2}\right)$ foi de $83,7 \%$, indicando um ótimo ajuste do modelo aos dados, o que garante a validade das predições efetuadas.

A Figura 13 mostra o efeito da umidade e temperatura sobre a diferença de cor das farinhas quando a rotação foi mantida no ponto central (210 rpm). Com a redução da umidade, independentemente da temperatura, a DCO aumentou. Os valores mais baixos de DCO ocorreram em elevada umidade e temperaturas intermediárias.

Os resultados obtidos neste trabalho mostraram que com o aumento da umidade da farinha de batata-doce até aproximadamente $20-21 \%$, houve aumento dos valores do componente $\mathrm{L}^{*}$ e o croma $\mathrm{a}^{*}$ tendeu ao negativo. Também o componente $\mathrm{b}^{*}$ e a DCO entre a farinha extrusada e a natural aumentaram com a redução da umidade. Neste caso, o baixo conteúdo de umidade durante o processamento da farinha de batata-doce favoreceu a ocorrência de reações de escurecimento não enzimático. Segundo Badrie \& Mellowes (1991) a elevação da temperatura aumenta a intensidade da cor e altos níveis de umidade resultam em produtos mais claros, pois o aumento da umidade reduz o tempo de residência, proporcionando menor escurecimento não enzimático dos produtos extrusados. 


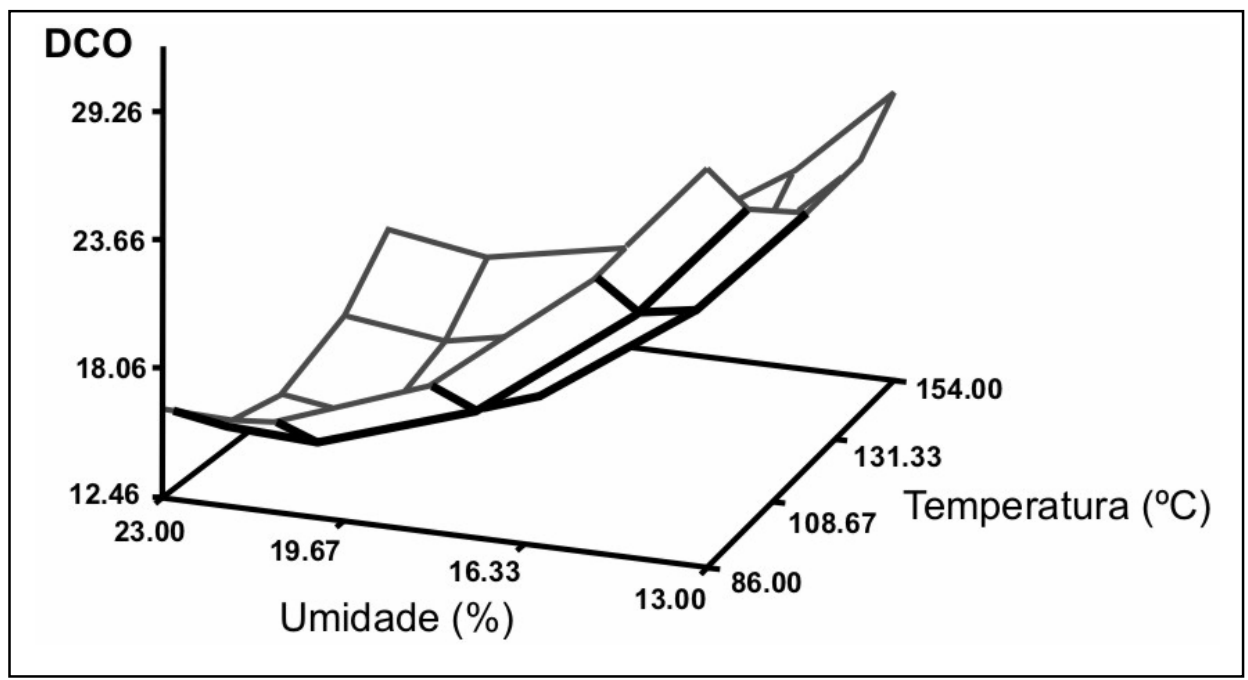

Figura 13 - Efeito dos teores de umidade das amostras e temperatura de extrusão, na diferença de cor das farinhas de batata-doce, sob rotação de $210 \mathrm{rpm}$

Iwe \& Ngoddy (1998) também verificaram o aumento da cor amarela $\left(+b^{*}\right)$ em farinhas de batata-doce e soja extrusadas sob baixas umidades. Neste caso, a umidade das farinhas variou de 18 a $30 \%$, a temperatura e a rotação foram mantidas a $100^{\circ} \mathrm{C}$ e $80 \mathrm{rpm}$, respectivamente.

Estudando a extrusão de farinha de inhame, sob condições de processamento de 18 a $26 \%$ de umidade, 100 a $150^{\circ} \mathrm{C}$ de temperatura e 100 a $200 \mathrm{rpm}$ de rotação, Sebio (1996) verificou que o valor da diferença de cor cresce à medida que a temperatura de processo se eleva, independentemente da variação da rotação da rosca. Segundo o autor, os valores mais baixos de DCO ocorreram quando a temperatura e a rotação estavam em seus níveis mais baixos, o que comprova que esses níveis não favoreceram a ocorrência de reações de escurecimento não enzimático, fator que compromete a cor dos produtos processados por extrusão. Não foi observado efeito significativo da umidade sobre a DCO.

Resultados diferentes do presente estudo foram obtidos por Gutkoski \& El-Dash (1999) em farinha de aveia extrusada, onde os valores de umidade do material variaram 
de 17 a $24 \%$ e a temperatura do extrusor variou de 90 a $150^{\circ} \mathrm{C}$, enquanto que a rotação foi mantida a $100 \mathrm{rpm}$. Estes verificaram que a luminosidade $\left(\mathrm{L}^{*}\right)$ da farinha de aveia extrusada diminuiu linearmente com o aumento da umidade inicial da mistura. Quando a temperatura de extrusão aumentou até $120^{\circ} \mathrm{C}$, a luminosidade diminuiu, e acima desta temperatura aumentou novamente. Os componentes $a^{*}$ e $b^{*}$ comportaram-se diferentemente do componente $\mathrm{L}^{*}$. Altos valores de $\mathrm{a}^{*}$ (vermelho) e $\mathrm{b}^{*}$ (amarelo) foram obtidos com altos níveis de umidade e temperatura média $\left(120^{\circ} \mathrm{C}\right)$. Baixos valores de $\mathrm{a}^{*}$ $\mathrm{e} \mathrm{b}^{*}$ foram obtidos quando a umidade foi baixa.

\subsection{3 Índice de absorção de água (IAA)}

O índice de absorção de água (IAA) está relacionado com a disponibilidade de grupo hidrofílicos $(-\mathrm{OH})$ em se ligar às moléculas de água e à capacidade de formação de gel das moléculas de amido. Somente os grânulos de amido gelatinizados absorvem água em temperatura ambiente e incham (Carvalho et al., 2002). Com o aumento do grau de gelatinização, aumenta a fragmentação do amido, e com isso, diminui a absorção de água (Gomez \& Aguilera, 1983).

Os índices de absorção de água das farinhas de batata-doce extrusadas mostraram uma variação de 5,0 a 6,2 g/g gel. Estes valores foram superiores aos obtidos para farinha não extrusada, que foi de $3,1 \mathrm{~g} / \mathrm{g}$ gel.

A equação do modelo total ajustado de $2^{\mathrm{a}}$ ordem para índice de absorção de água da farinha extrusada está expresso na equação 10 .

$$
\begin{aligned}
& \text { IAA }=-1,06-0,43 U+0,0516 \mathrm{~T}+0,072 \mathrm{R}+0,0175 \mathrm{U}^{2}+0,000019 \mathrm{~T}^{2}-0,000093 \mathrm{R}^{2} \\
& -0,000437 \mathrm{UT}-0,000625 \mathrm{UR}-0,000223 \mathrm{TR}\left({ }^{\mathrm{p}>10 \%} \mathrm{R}^{2}: 39,41 \%\right)
\end{aligned}
$$

Onde: $\mathrm{U}=$ umidade da mistura; $\mathrm{T}=$ temperatura $; \mathrm{R}=$ rotação da rosca

A análise de variância (ANOVA) do modelo total ajustado para índice de absorção de água das farinhas extrusadas está apresentada na Tabela 14. 
Tabela 14. Análise de Variância dos fatores e regressão para IAA das farinhas extrusadas

\begin{tabular}{llllll}
\hline Causa da variação & GL & SQ & F & Pr $>$ F & $\mathrm{R}^{2}$ \\
\hline Umidade & 4 & 0,398 & 0,69 & 0,62 & 0,099 \\
Temperatura & 4 & 0,163 & 0,28 & 0,88 & 0,041 \\
Rotação & 4 & 0,521 & 0,90 & 0,50 & 0,130 \\
Regressão & 9 & 0,945 & 0,66 & 0,59 & 0,394 \\
Resíduos & 10 & 1,454 & - & - & 0,145 \\
\hline
\end{tabular}

O modelo de regressão adotado para este parâmetro não foi significativo ( $\mathrm{p}$ > 0,10) para este parâmetro. O coeficiente de correlação múltipla $\left(\mathrm{R}^{2}\right)$ foi de $39,4 \%$, indicando falta de ajuste do modelo aos dados. Entretanto, pode-se observar que os maiores valores de IAA $(6,0$ a $6,2 \mathrm{~g} / \mathrm{g}$ gel) foram obtidos com baixa rotação da rosca (180 rpm). Os menores valores de IAA ( 5,0 a $5,5 \mathrm{~g} / \mathrm{g}$ gel) foram obtidos nas temperaturas e rotações mais elevadas.

Segundo Guha et al. (1997) a redução do IAA está relacionada à degradação da molécula de amido, que interfere na capacidade das moléculas em absorver água. Os autores estudaram extrusão de farinha de arroz. Os valores de umidade, temperatura e rotação utilizados foram 14,2\%, 80 a $120^{\circ} \mathrm{C}$ e 200 a $400 \mathrm{rpm}$, respectivamente. Em baixas rotações e temperatura do extrusor, os valores de IAA apresentaram-se relativamente mais altos que em elevadas rotações e temperaturas. Segundo os autores a baixa velocidade do parafuso permitiu maior tempo de residência da mistura no extrusor e maior cocção das amostras.

Segundo Gomez \& Aguilera (1983) o baixo cisalhamento (ou baixa velocidade do parafuso) e/ou baixa temperatura, permitem maiores cadeias de polímeros não danificados e uma grande disponibilidade de grupos hidrofílicos, aos quais ligam-se mais moléculas de água, resultando em altos valores de IAA.

Iwe (1998) também obteve resultados semelhantes para farinha de batata-doce extrusada, onde o aumento da rotação reduziu o IAA e os baixos valores de rotação resultaram em maiores valores de IAA. Os valores de umidade no trabalho do autor 
variaram de 18 a $22 \%$, a temperatura variou de 120 a $150^{\circ} \mathrm{C}$ e a rotação de rosca de 180 a $220 \mathrm{rpm}$.

$\mathrm{Na}$ extrusão de farelo e amido de mandioca, Hashimoto \& Grossmann (2003) verificaram que o aumento da temperatura resultou em redução do IAA. Os autores atribuíram o fato à possível degradação do amido. A umidade variou de 16 a 20\%, os valores de temperatura variaram de 150 a $210^{\circ} \mathrm{C}$ e a rotação de 120 a $180 \mathrm{rpm}$.

Iwe \& Ngoddy (1998) ao estudar a extrusão de misturas de farinha de batatadoce e de soja, com os valores de umidade variando de 18 a $30 \%$, a temperatura e a rotação de rosca mantidas constantes a $100^{\circ} \mathrm{C}$ e $80 \mathrm{rpm}$, respectivamente, observaram que a umidade afetou muito pouco os valores de IAA.

Anderson et al. (1969) extrusaram milho com a umidade variando de 15 a $25 \%$ e a temperatura de 121 a $299^{\circ} \mathrm{C}$. O IAA dos extrusados foi reduzido conforme a temperatura do processo foi elevada.

Segundo Chang et al. (2001) a baixa capacidade de absorver água poderia ser desejável em produtos extrusados onde a integridade estrutural e a termoestabilidade do produto seriam importantes.

\subsection{4 Índice de solubilidade em água (ISA)}

O índice de solubilidade em água é um parâmetro que reflete o grau de degradação total do grânulo de amido, ou seja, a somatória dos efeitos de gelatinização, dextrinização e conseqüente solubilização. $\mathrm{O}$ aumento da solubilidade verificado em produtos extrusados é atribuído à dispersão das moléculas de amilose e amilopectina como conseqüência da gelatinização, quando as condições são mais brandas, e da formação de compostos de baixo peso molecular, quando estas são mais drásticas (Colonna et al., 1984)

O índice de solubilidade em água das farinhas de batata-doce extrusadas variou de 10,67 a 22,16\%. Estes valores são semelhantes aos encontrados por Iwe (1998) em misturas de batata-doce e soja extrusadas, ou seja, 15,20 a 19,24\%. 
O polinômio descrito na equação 11 corresponde ao modelo total ajustado de $2^{\mathrm{a}}$ ordem para índice de solubilidade em água da farinha extrusada.

$$
\begin{aligned}
& \mathrm{ISA}=-51,81+2,47 \mathrm{U}+0,62 \mathrm{~T}+0,069 \mathrm{R}+0,0246 \mathrm{U}^{2}-0,00133 \mathrm{~T}^{2}-0,00043 \mathrm{R}^{2} \\
& -0,026 \mathrm{UT}-0,000375 \mathrm{UR}+0,00084 \mathrm{TR}\left({ }^{\mathrm{p}>10 \%} \mathrm{R}^{2}: 25,4 \%\right)
\end{aligned}
$$

Onde: $\mathrm{U}=$ umidade da mistura $\mathrm{T}=$ temperatura de extrusão; $\mathrm{R}=$ rotação da rosca

A análise de variância (ANOVA) do modelo total ajustado para índice de solubilidade em água das farinhas extrusadas está apresentada na Tabela 15.

Tabela 15. Análise de Variância dos fatores e regressão para ISA das farinhas extrusadas

\begin{tabular}{llllll}
\hline Causa da variação & GL & SQ & F & Pr $>$ F & $\mathrm{R}^{2}$ \\
\hline Umidade & 4 & 23,04 & 0,55 & 0,70 & 5,760 \\
Temperatura & 4 & 25,97 & 0,62 & 0,65 & 6,492 \\
Rotação & 4 & 7,84 & 0,19 & 0,94 & 1,961 \\
Regressão & 9 & 35,44 & 0,38 & 0,92 & 0,254 \\
Resíduos & 10 & 104,05 & - & - & 10,405 \\
\hline
\end{tabular}

O modelo de regressão adotado não foi significativo $(\mathrm{p}>0,10)$ para este parâmetro. $\mathrm{O}$ coeficiente de correlação múltipla $\left(\mathrm{R}^{2}\right)$ foi de $25,4 \%$, indicando falta de ajuste do modelo aos dados.

No geral, os menores valores de ISA foram obtidos quando a rotação foi alta. Os maiores valores de ISA foram obtidos com baixa umidade, baixa rotação e alta temperatura.

Mercier \& Feillet (1975) avaliaram o efeito da temperatura de extrusão sobre os grãos de milho, com valores de umidade variando de 10,5 a $28,5 \%$ e a rotação de 20 e $120 \mathrm{rpm}$. Quando a temperatura aumentou de $70^{\circ} \mathrm{C}$ a $250^{\circ} \mathrm{C}$, o ISA se elevou também.

O mesmo foi obtido por Carvalho et al. (2002) com extrusão de misturas de farinhas de trigo, arroz e banana, com temperatura variando de 60 a $80^{\circ} \mathrm{C}$ e os teores de 
umidade de 30 a 40\%, sob rotação de $100 \mathrm{rpm}$. Altas temperaturas e baixos teores de água resultaram em maior degradação dos grânulos de amido, contribuindo assim, para o aumento do ISA.

Anderson et al. (1969) também verificaram que o ISA de milho extrusado se eleva com o aumento da temperatura de extrusão quando a umidade da mistura é baixa (15\%). No experimento destes autores, a umidade variou de 15 a $25 \%$ e a temperatura de 121 a $299^{\circ} \mathrm{C}$.

Segundo Hashimoto \& Grossmann (2003) e Guha et al. (1997) o aumento da velocidade da rosca resulta em maior fragmentação do amido devido a maior severidade no tratamento.

\subsubsection{Viscoamilograma}

Os parâmetros avaliados foram viscosidade inicial, pico de viscosidade, quebra de viscosidade, tendência à retrogradação e viscosidade final.

\subsubsection{Viscosidade inicial a $25^{\circ} \mathrm{C}$ (VI)}

A viscosidade inicial a $25^{\circ} \mathrm{C}$, também chamada de viscosidade de pasta a frio, indica a capacidade das farinhas em absorver água a temperatura ambiente e formar uma pasta, gel ou líquido viscoso (Carvalho et al., 2002).

Segundo Colonna et al. (1987), comparado aos produtos submetidos a outros tratamentos térmicos, a principal desvantagem dos amidos que passaram por extrusão é a sua reduzida viscosidade de pasta. Em contraste, sua lenta dispersão em água fria, e rápida dispersão em água quente a formar produtos de várias consistência, permite o uso comercial desta técnica para produção de alimentos instantâneos.

A VI das farinhas extrusadas variou de 17 a 45 RVU, enquanto que a VI da farinha crua foi 2 RVU. Nas amostras extrusadas o amido já está gelatinizado, o qual torna possível a rápida hidratação comparada a amostra crua. Esta característica é desejável em produtos amiláceos, onde se deseja obter uma boa viscosidade a frio para o produto. 
A equação do modelo total ajustado de $2^{\mathrm{a}}$ ordem para viscosidade inicial das farinhas de batata-doce extrusadas está representada na equação 12 .

$$
\begin{aligned}
& \mathrm{VI}=238,18-22,40 \mathrm{U}+0,266 \mathrm{~T}+0,017 \mathrm{R}+0,368 \mathrm{U}^{2}-0,000657 \mathrm{~T}^{2}-0,00014 \mathrm{R}^{2} \\
& +0,0196 \mathrm{UT}+0,0241 \mathrm{UR}-0,0040 \mathrm{TR}\left({ }^{7} \% \mathrm{R}^{2}: 70,80 \%\right)
\end{aligned}
$$

Onde: $\mathrm{U}=$ umidade da mistura; $\mathrm{T}=$ temperatura de extrusão; $\mathrm{R}=$ rotação da rosca

A análise de variância (ANOVA) do modelo total ajustado para viscosidade inicial das farinhas de batata-doce extrusadas está apresentada na Tabela 16.

Tabela 16. Análise de Variância dos fatores e regressão obtida para a viscosidade inicial das farinhas extrusadas

\begin{tabular}{llllll}
\hline Causa da variação & GL & SQ & F & Pr $>$ F & $\mathrm{R}^{2}$ \\
\hline Umidade & 4 & 564,88 & 4,71 & 0,0214 & 141,22 \\
Temperatura & 4 & 78,75 & 0,66 & 0,636 & 19,689 \\
Rotação & 4 & 176,73 & 1,47 & 0,281 & 44,184 \\
Regressão & 9 & 727,19 & 2,69 & 0,069 & 0,708 \\
Resíduos & 10 & 299,96 & - & - & 29,996 \\
\hline
\end{tabular}

O modelo de regressão adotado foi significativo $(\mathrm{p}<0,07)$ para este parâmetro. Dentre os fatores que compõem o modelo, a umidade $(p=0,021)$ afetou significativamente a VI, ao passo que não houve efeito significativo para os fatores temperatura de extrusão e rotação da rosca. O coeficiente de correlação múltipla $\left(\mathrm{R}^{2}\right)$ foi de $70,80 \%$, indicando um bom ajuste do modelo aos dados, o que garante a validade das predições efetuadas.

A Figura 14 mostra o efeito da umidade na viscosidade inicial quando a temperatura e rotação foram mantidos no ponto central $\left(120^{\circ} \mathrm{C}\right.$ e $\left.210 \mathrm{rpm}\right)$. Com o aumento da umidade até 20-21\%, houve uma redução da viscosidade a frio. A partir daí houve aumento da VI. Teores de umidade mais elevados provavelmente exercem efeito 
lubrificante no material durante a extrusão, impedindo a alta degradação do amido. Porém, tratamentos com menores teores de umidade também resultaram em valores de VI mais elevados.

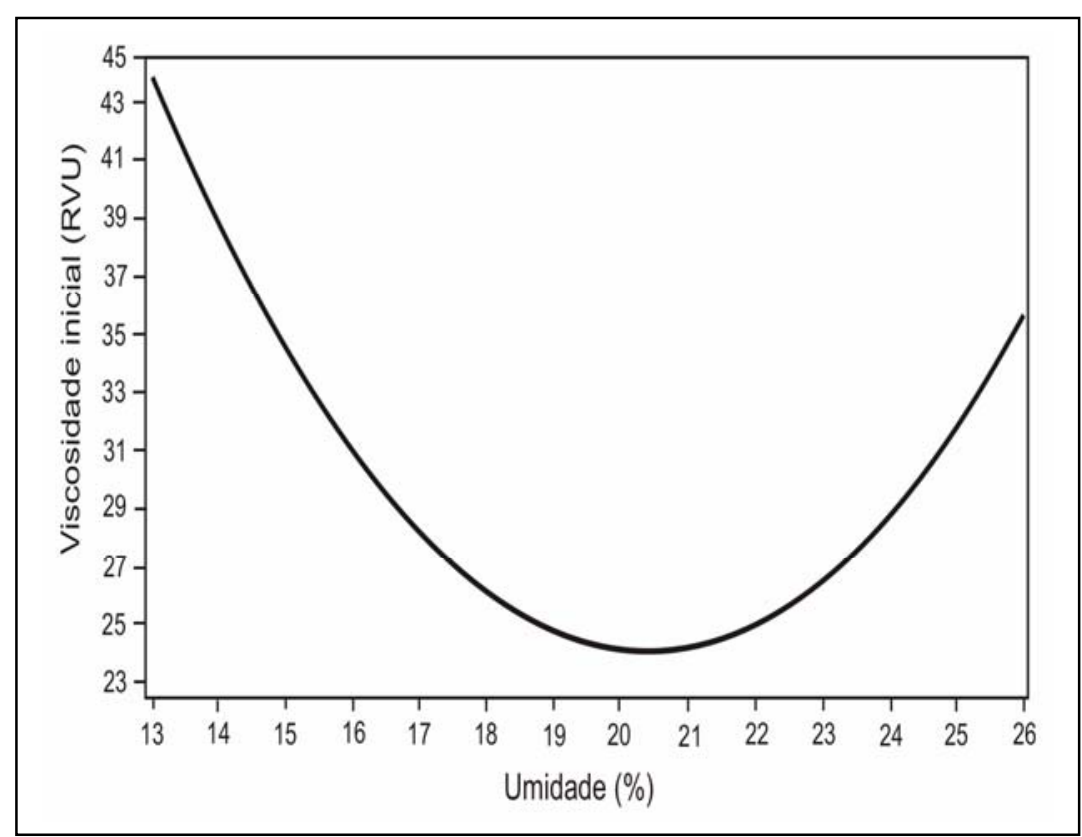

Figura 14 - Efeito dos teores de umidade da mistura sobre a viscosidade inicial das farinhas de batata-doce extrusadas, em temperatura de $120^{\circ} \mathrm{C}$ e rotação de $210 \mathrm{rpm}$

Whalen et al. (1997) extrusaram farinha de arroz, trigo e milho, com a temperatura variando de 160 a $190^{\circ} \mathrm{C}$ e a rotação de rosca constante a $200 \mathrm{rpm}$. Os autores também observaram aumento da viscosidade a frio com a redução do teor de umidade das misturas de 29 para $15 \%$.

Sebio (1996) também obteve resultados semelhantes em farinha de inhame extrusada. Os valores utilizados de umidade, temperatura e rotação de rosca foram 18 a 
$26 \%, 100$ a $150^{\circ} \mathrm{C}$ e 100 a $200 \mathrm{rpm}$, respectivamente. A viscosidade inicial foi inversamente proporcional ao conteúdo de umidade.

Carvalho et al. (2002) obtiveram o mesmo efeito da umidade em misturas de farinha de trigo, arroz e banana, com valores de temperatura variando de 60 a $80^{\circ} \mathrm{C}$ e a rotação de rosca mantida a $100 \mathrm{rpm}$. A umidade variou de modo inversamente proporcional à viscosidade inicial. Porém, a umidade utilizada pelos autores, que variou de 30 a $40 \%$, corresponde aos valores mais altos de umidade deste trabalho. De acordo com estes autores, os tratamentos com menor porcentagem de umidade permitem que suas estruturas amiláceas estejam sujeitas a uma maior degradação que os tratamentos com maior umidade. Provavelmente as matérias-primas e as condições de processamento utilizadas influenciaram nas características do produto extrusado.

Mercier \& Feillet (1975) demonstraram que há uma relação indireta entre a umidade da mistura e o grau de degradação em milho extrusado. Neste caso, foi observado aumento da viscosidade inicial do extrusado com o incremento dos valores de umidade, que variaram de 10,5 a $28,5 \%$. Os valores de temperatura e rotação utilizados neste trabalho foram 70 a $250^{\circ} \mathrm{C}$ e 20 e $120 \mathrm{rpm}$, respectivamente. Gomez \& Aguilera (1983) também observaram o aumento da viscosidade inicial com a elevação da umidade de 7,6 para 23,7\% em extrusão de pasta de milho.

Segundo Sebio (1996) o efeito da umidade na viscosidade inicial pode ser explicado pela lubrificação que o alto teor de água provoca na rosca do extrusor evitando assim maior ocorrência de degradação mecânica dos grânulos de amido obtendo-se, portanto, valores altos de VI.

\subsubsection{Pico de viscosidade (PV)}

Este parâmetro se refere ao pico de viscosidade após o início do aquecimento e antes do início do resfriamento da suspensão no viscoamilógrafo. Se os tratamentos não forem tão severos, determinada porcentagem de grânulos de amido pode conservar parte da estrutura amilácea, apresentando um pico no perfil amilográfico, que representa o amido não gelatinizado ou parcialmente gelatinizado (Guha et al., 1998). Entretanto, no 
processo de extrusão, dependendo das condições do processo, o tratamento térmico pode destruir a estrutura cristalina do amido, de tal forma que, no ciclo de aquecimento, o viscoamilograma apresenta ausência de pico ou valores muito baixos de viscosidade (Carvalho et al., 2002).

Os picos de viscosidade das farinhas extrusadas (17,8 a 44,8 RVU) foram inferiores aos da farinha natural que foi de 69,8 RVU, devido a gelatinização do amido durante o processo de extrusão. Esta variação indica diferentes graus de gelatinização entre os tratamentos efetuados.

A equação do modelo total ajustado de $2^{\mathrm{a}}$ ordem para pico de viscosidade das farinhas extrusadas está expresso na equação 13.

$$
\begin{aligned}
& P V=192,91-20,03 U+0,621 T+0,0585 R+0,34 U^{2}-0,000359 T^{2}-0,000131 R^{2} \\
& +0,0129 U T+0,0219 U R-0,0041 T R\left({ }^{8 \%} R^{2}: 69,31 \%\right)
\end{aligned}
$$

Onde: $\mathrm{U}=$ umidade da mistura; $\mathrm{T}=$ temperatura de extrusão; $\mathrm{R}$ = rotação da rosca

A análise de variância (ANOVA) do modelo total ajustado para pico de viscosidade das farinhas extrusadas está apresentada na Tabela 17.

Tabela 17. Análise de Variância dos fatores e regressão para pico de viscosidade das farinhas extrusadas

\begin{tabular}{llllll}
\hline Causa da variação & GL & SQ & F & Pr $>$ F & $\mathrm{R}^{2}$ \\
\hline Umidade & 4 & 489,66 & 4,07 & 0,033 & 122,415 \\
Temperatura & 4 & 92,19 & 0,77 & 0,571 & 23,049 \\
Rotação & 4 & 177,34 & 1,47 & 0,282 & 44,336 \\
Regressão & 9 & 680,13 & 2,51 & 0,084 & 0,693 \\
Resíduos & 10 & 301,13 & - & - & 30,113 \\
\hline
\end{tabular}


O modelo de regressão adotado para este parâmetro foi significativo $(\mathrm{p}<0,08)$. Dentre os fatores que compõem o modelo, a umidade $(\mathrm{p}=0,0328)$ afetou significativamente o pico de viscosidade, ao passo que os fatores temperatura e rotação de rosca não afetaram significativamente o pico de viscosidade. O coeficiente de correlação múltipla $\left(\mathrm{R}^{2}\right)$ foi de $69,3 \%$, indicando um bom ajuste do modelo aos dados, o que garante a validade das predições efetuadas.

A Figura 15 mostra o efeito da umidade no PV das farinhas quando a temperatura de extrusão e a rotação da rosca foram mantidos no ponto central $\left(120^{\circ} \mathrm{C}\right.$ e $210 \mathrm{rpm}$ ). Com o aumento da umidade houve uma redução do PV até 20-21\%, e após isto, elevação do PV das amostras. Os PV mais elevados foram obtidos nas farinhas extrusadas com teores mais baixos de umidade, ou seja, em torno de 13-14\%, que correspondem aos tratamentos que também obtiveram maiores valores de VI. Deste modo, os altos PV ocorreram mais devido aos altos valores de VI do que devido a presença de amido não-gelatinizado, já que as diferenças entre a VI e PV dentro do mesmo tratamento foi mínima.

Gomez \& Aguilera (1983) verificaram ausência do pico de viscosidade em análises no viscoamilógrafo, em pasta de milho extrusado. Segundo os autores isto revela que os grânulos de amido que estavam presentes nos extrusados se encontravam totalmente gelatinizados.

Whalen et al. (1997) verificaram o inverso com relação aos resultados obtidos neste trabalho em farinha de arroz, trigo e milho extrusados, onde a temperatura variou de 160 a $190^{\circ} \mathrm{C}$ e a rotação foi mantida a $200 \mathrm{rpm}$. Segundo autores, a diminuição da umidade (de 29 para 15\%) resultou em redução no PV das farinhas extrusadas. 


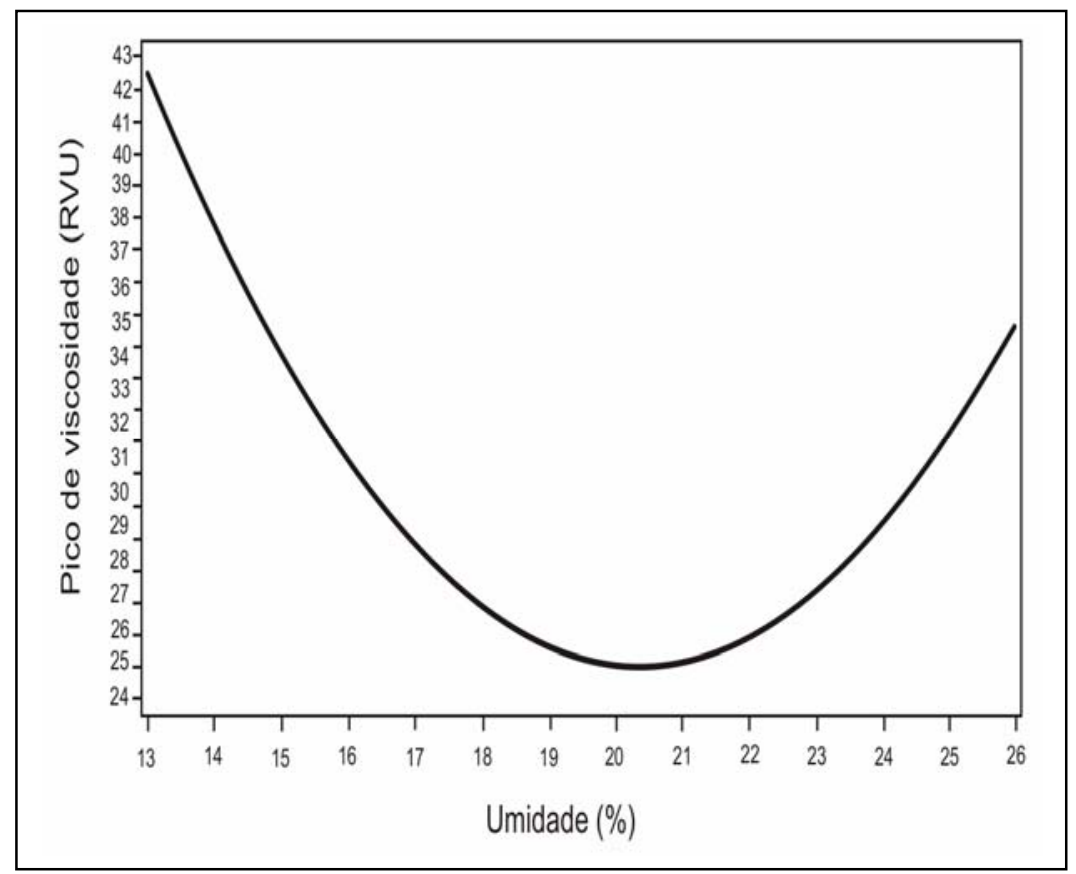

Figura 15 - Efeito dos teores de umidade da mistura, em temperatura de $120^{\circ} \mathrm{C}$ e rotação de rosca de $210 \mathrm{rpm}$, sobre o pico de viscosidade das farinhas de batata-doce extrusadas

\subsubsection{Quebra de viscosidade (QV)}

A quebra de viscosidade representa a diferença entre o pico de viscosidade e o menor valor de viscosidade após o pico no perfil amilográfico. Através desta propriedade é possível avaliar a estabilidade do amido em altas temperaturas, sob agitação mecânica.

A QV da farinha não extrusada foi superior (49 RVU) às apresentadas pelas farinhas extrusadas, que variaram de 12 a $36 \mathrm{RVU}$, o que era esperado, uma vez que os picos de viscosidade das farinhas extrusadas foram bem menores que o da farinhas não extrusada, e também devido a degradação já sofrida pelo amido durante a extrusão.

A equação do modelo total ajustado de $2^{\mathrm{a}}$ ordem para quebra de viscosidade das farinhas extrusadas está representada na equação 14 . 
$\mathrm{QV}=222,59-22,64 \mathrm{U}+0,375 \mathrm{~T}-0,0327 \mathrm{R}+0,377 \mathrm{U}^{2}-0,00085 \mathrm{~T}^{2}-0,000965 \mathrm{R}^{2}$

$+0,00608 \mathrm{UT}+0,0324 \mathrm{UR}-0,00152 \mathrm{TR} \quad\left({ }^{1 \%} \mathrm{R}^{2}: 82,05 \%\right)$

Onde: $\mathrm{U}=$ umidade da mistura; $\mathrm{T}=$ temperatura de extrusão; $\mathrm{R}=$ rotação da rosca

A análise de variância (ANOVA) do modelo total ajustado para quebra de viscosidade das farinhas extrusadas está apresentada na Tabela 18.

Tabela 18. Análise de Variância dos fatores e regressão para quebra de viscosidade das farinhas extrusadas

\begin{tabular}{llllll}
\hline Causa da variação & GL & SQ & F & Pr $>$ F & $\mathrm{R}^{2}$ \\
\hline Umidade & 4 & 514,33 & 10,32 & 0,0014 & 128,584 \\
Temperatura & 4 & 17,42 & 0,35 & 0,8386 & 4,356 \\
Rotação & 4 & 101,52 & 2,04 & 0,1649 & 25,381 \\
Regressão & 9 & 569,76 & 5,08 & 0,0091 & 0,8205 \\
Resíduos & 10 & 124,64 & - & - & 12,464 \\
\hline
\end{tabular}

O modelo de regressão adotado para este parâmetro foi significativo $(\mathrm{p}<0,009)$. Dentre os fatores que compõem o modelo, a umidade $(\mathrm{p}=0,0014)$ afetou significativamente a quebra de viscosidade das farinhas, ao passo que não houve efeito significativo dos fatores temperatura de extrusão e rotação de rosca. O coeficiente de correlação múltipla $\left(\mathrm{R}^{2}\right)$ foi de $82,1 \%$, indicando um ótimo ajuste do modelo aos dados, o que garante a validade das predições efetuadas.

A Figura 16 mostra o efeito da umidade da matéria-prima sobre a quebra de viscosidade das farinhas extrusadas quando a temperatura e rotação da rosca foram mantidas no ponto central, respectivamente $120^{\circ} \mathrm{C}$ e $210 \mathrm{rpm}$. Foi observada redução da quebra de viscosidade com o aumento da umidade até 19-21\%, após este teores aconteceu o inverso. Pelo gráfico, os valores mais elevados de QV tenderam a ocorrer nos menores teores de umidade (13-14\%) testados. As farinhas extrusadas com teores 
médios (pontos centrais) de umidade apresentaram menores valores de QV. Estes resultados foram devido aos baixos valores de PV que estes tratamentos também apresentaram.

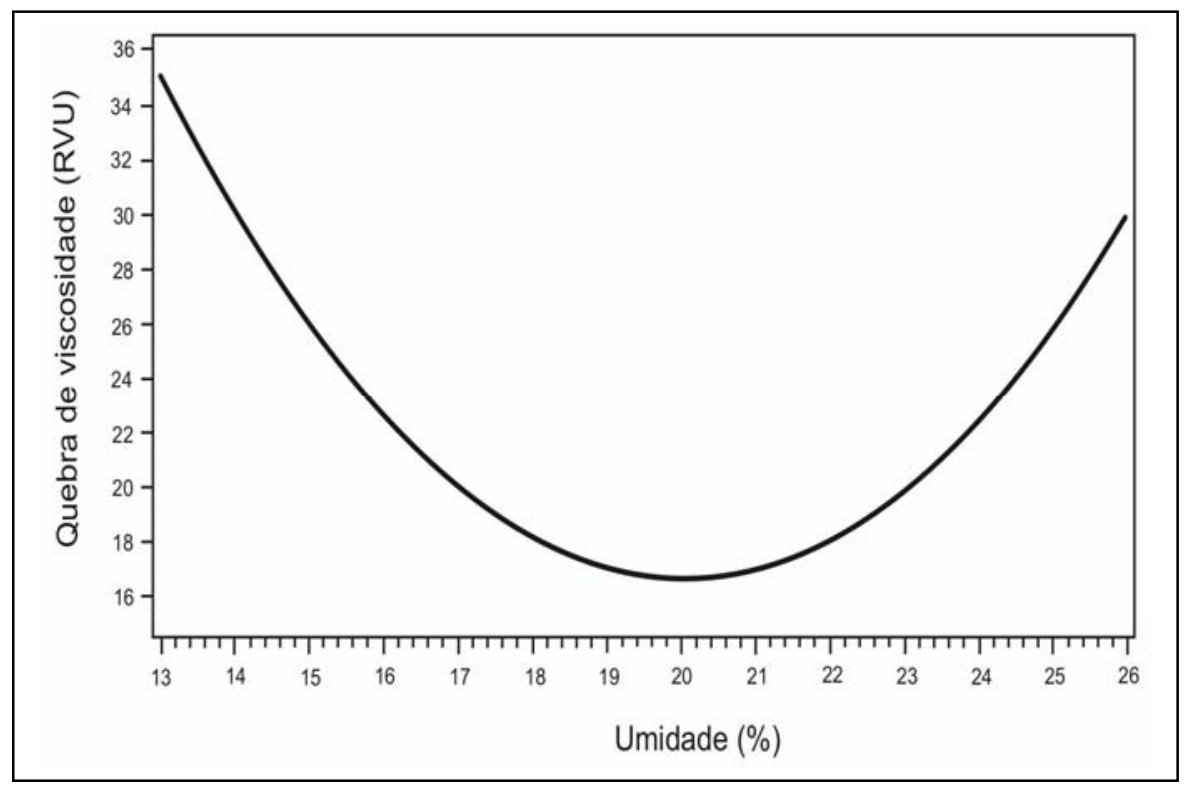

Figura 16 - Efeito dos teores de umidade da matéria-prima sobre a quebra de viscosidade das farinhas de batata-doce extrusadas, sob temperatura de $120^{\circ} \mathrm{C}$ e rotação de rosca de $210 \mathrm{rpm}$

Comportamento oposto foi encontrado por Bhattacharya et al. (1999) ao estudar extrusão de misturas de farinha de batata e de trigo, onde a temperatura foi mantida a $160^{\circ} \mathrm{C}$ e rotação de rosca variou de 200 a $400 \mathrm{rpm}$. Os menores valores de QV foram obtidos em baixa umidade (15,5\%) e a elevação desse teor para $20,7 \%$ proporcionou aumento significativo nos valores de QV. Segundo estes autores, os elevados teores de umidade na matéria-prima poderiam estar agindo como lubrificantes, reduzindo a viscosidade de fusão durante a extrusão e elevando os valores de QV. 


\subsubsection{Tendência a retrogradação (TR)}

A tendência a retrogradação mede a diferença entre a viscosidade final e o menor valor de viscosidade após o pico. Esta propriedade permite avaliar o comportamento do amido durante a fase de resfriamento.

A retrogradação do amido ocorre por efeito da recristalização das moléculas de amilose e amilopectina (Carvalho et al., 2002), decorrente do agrupamento das partes lineares das moléculas do amido através da formação de novas ligações de hidrogênio, resultando na formação de precipitados e/ou géis (Gutkoski, 2000).

Os valores de tendência a retrogradação das farinhas extrusadas variaram de 17,4 a 29,4 RVU. Alguns tratamentos apresentaram valores próximos ao da farinha natural (31 RVU).

A equação do modelo total ajustado de $2^{\mathrm{a}}$ ordem para a tendência a retrogradação das farinhas extrusadas está expressa na equação 15.

$$
\begin{aligned}
& \mathrm{TR}=24,156-0,457 \mathrm{U}+0,316 \mathrm{~T}-0,109 \mathrm{R}+0,136 \mathrm{U}^{2}+0,0012 \mathrm{~T}^{2}+0,00128 \mathrm{R}^{2} \\
& -0,0108 \mathrm{UT}-0,0147 \mathrm{UR}-0,00196 \mathrm{TR} \quad\left({ }^{\mathrm{p}>10 \%} \mathrm{R}^{2}: 59,83 \%\right)
\end{aligned}
$$

Onde: $\mathrm{U}=$ umidade da mistura; $\mathrm{T}=$ temperatura de extrusão; $\mathrm{R}=$ rotação da rosca

A análise de variância (ANOVA) do modelo total ajustado para a tendência a retrogradação das farinhas extrusadas está apresentada na Tabela 19.

Tabela 19. Análise de Variância dos fatores e regressão para tendência a retrogradação das farinhas extrusadas

\begin{tabular}{llllll}
\hline Causa da variação & GL & SQ & F & Pr $>$ F & $\mathrm{R}^{2}$ \\
\hline Umidade & 4 & 38,455 & 1,10 & 0,41 & 9,614 \\
Temperatura & 4 & 17,927 & 0,51 & 0,73 & 4,482 \\
Rotação & 4 & 108,40 & 3,09 & 0,067 & 27,010 \\
Regressão & 9 & 130,59 & 1,66 & 0,2217 & 0,598 \\
Resíduos & 10 & 87,66 & - & - & 8,767 \\
\hline
\end{tabular}


O modelo de regressão adotado não foi significativo $(\mathrm{p}>0,10)$ para este parâmetro. O coeficiente de correlação múltipla $\left(\mathrm{R}^{2}\right)$ foi de $59,8 \%$, indicando falta de ajuste do modelo aos dados.

Os maiores valores de TR (26 - 29 RVU) das farinhas extrusadas aconteceram em rotação de rosca inferior (180rpm) e os menores valores de TR (17-18 RVU), em rotações elevadas (240 e $260 \mathrm{rpm}$ ). A retrogradação é a tendência das moléculas de se recristalizarem. Em tratamentos mais severos, onde os valores de TR são menores, ocorre maior degradação dos polímeros, com rompimento das estruturas moleculares e redução da capacidade de recristalização dos mesmos.

Whalen et al. (1997) estudaram extrusão de farinha de milho sob teor de umidade variando de 15 a $29 \%$, a temperatura de 160 a $190^{\circ} \mathrm{C}$ e a rotação mantida a 200rpm. e Carvalho et al. (2002) estudaram a extrusão de mistura de farinhas de trigo, arroz e banana com teores de umidade entre 30 e 40\%, temperatura variando de 60 a $80^{\circ} \mathrm{C}$ e a rotação mantida a $100 \mathrm{rpm}$. Em ambos os trabalhos a tendência a retrogradação diminuiu com a redução da umidade.

De acordo com Gutkoski \& El Dash (1999) baixas umidades da matéria-prima e altas temperaturas de extrusão resultam em extrusados caracterizados por baixos graus de retrogradação, enquanto que altas umidades produzem extrusados com elevada tendência a retrogradação.

\subsubsection{Viscosidade final (VF)}

A viscosidade final é uma característica que, em produtos extrusados, vai depender das modificações que ocorrem nas estruturas do grânulo de amido e das moléculas durante o processamento (El-Dash, 1982).

A VF das farinhas extrusadas variou de 25 a 43 RVU, sendo que o valor da farinha não extrusada foi 52 RVU.

A equação do modelo de regressão linear para viscosidade final (VF) das farinhas extrusadas está expressa na equação 16 . 
$V F=-5,518+2,146 U+0,562 T-0,0166 R \quad\left({ }^{10 \%} R^{2}: 33,61 \%\right)$

Onde: $\mathrm{U}=$ umidade da mistura; $\mathrm{T}$ = temperatura de extrusão; $\mathrm{R}$ = rotação da rosca

A análise de variância (ANOVA) do modelo total ajustado para viscosidade final das farinhas extrusadas está apresentada na Tabela 20.

Tabela 20. Análise de Variância dos fatores e regressão para viscosidade final das farinhas extrusadas

\begin{tabular}{llllll}
\hline Causa da variação & GL & SQ & F & Pr $>$ F & $\mathrm{R}^{2}$ \\
\hline Umidade & 4 & 53,39 & 0,54 & 0,71 & 13,348 \\
Temperatura & 4 & 78,13 & 0,78 & 0,56 & 19,532 \\
Rotação & 4 & 344,77 & 3,46 & 0,05 & 86,192 \\
Regressão linear & 3 & 207,41 & 2,78 & 0,0964 & 0,3361 \\
Resíduos & 10 & 248,99 & - & - & 24,899 \\
\hline
\end{tabular}

O modelo de regressão adotado não foi significativo $(p>0,10)$ para este parâmetro, entretanto, a regressão linear mostrou-se significativa em nível de p =0,096. Dentre os fatores que compõem a regressão linear, a rotação $(p=0,0506)$ afetou significativamente a viscosidade final das farinhas extrusadas, ao passo que não houve efeito significativo dos fatores umidade e temperatura. $\mathrm{O}$ coeficiente de correlação múltipla $\left(\mathrm{R}^{2}\right)$ foi de $33,6 \%$, indicando falta de ajuste do modelo aos dados.

A Figura 17 mostra como a rotação da rosca interfere na viscosidade final das farinhas extrusadas, tendo a umidade $(18 \%)$ e temperatura $\left(120^{\circ} \mathrm{C}\right)$ mantidas no ponto central. A viscosidade final das farinhas extrusadas foi inversamente proporcional à rotação da rosca, ou seja, a VF diminui a medida que a rotação da rosca foi elevada. 


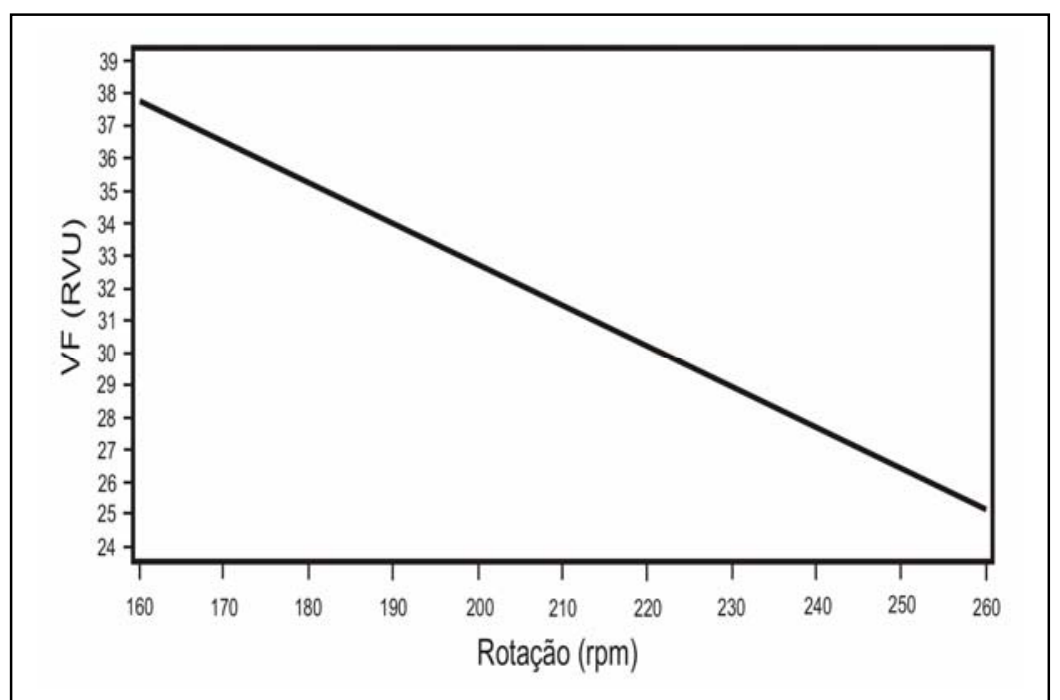

Figura 17 - Efeito da rotação da rosca sobre a viscosidade final das farinhas extrusadas, sob teor de umidade de $18 \%$ e temperatura de extrusão de $120^{\circ} \mathrm{C}$

Sebio (1996) também constatou o efeito inverso da rotação da rosca sobre a VF das farinhas extrusadas. Segundo o autor, os menores valores de VF são obtidos em tratamentos severos, onde ocorre degradação dos grânulos de amido e possíveis rompimentos de suas estruturas moleculares, que causam a perda da capacidade de retrogradação das mesmas, diminuindo a viscosidade no resfriamento.

\subsubsection{Grau de gelatinização (GG)}

A gelatinização do amido afeta a qualidade do alimento por influenciar a textura (elasticidade e maciez), digestibilidade, palatibilidade, volume e vida útil dos produtos (Chiang \& Johnson, 1977). A gelatinização do amido produz alterações estruturais significativas, destruindo as cadeias de polímeros e permitindo sua liberação (Gomez \& Aguilera, 1983).

A equação do modelo total ajustado de $2^{\mathrm{a}}$ ordem para grau de gelatinização das farinhas extrusadas está representada na equação 17. 
$\mathrm{GG}=153,51-5,055 \mathrm{U}+0,996 \mathrm{~T}-0,859 \mathrm{R}+0,176 \mathrm{U}^{2}-0,0002 \mathrm{~T}^{2}+0,00078 \mathrm{R}^{2}$

$-0,0533 \mathrm{UT}+0,0254 \mathrm{UR}+0,00076 \mathrm{TR}\left({ }^{\mathrm{p}>10 \%} \mathrm{R}^{2}: 62,68\right)$

Onde: $\mathrm{U}=$ umidade da mistura; $\mathrm{T}$ = temperatura de extrusão; $\mathrm{R}$ = rotação da rosca

A análise de variância (ANOVA) do modelo total ajustado para grau de gelatinização das farinhas extrusadas está apresentada na Tabela 21.

Tabela 21. Análise de Variância dos fatores estudados e da regressão para grau de gelatinização das farinhas extrusadas

\begin{tabular}{llllll}
\hline Causa da variação & GL & SQ & F & Pr $>$ F & $\mathrm{R}^{2}$ \\
\hline Umidade & 4 & 163,59 & 2,33 & 0,1265 & 40,897 \\
Temperatura & 4 & 203,49 & 2,90 & 0,078 & 50,872 \\
Rotação & 4 & 54,191 & 0,77 & 0,5673 & 13,548 \\
Regressão & 9 & 294,59 & 1,87 & 0,1724 & 0,6268 \\
Resíduos & 10 & 175,37 & - & - & 17,537 \\
\hline
\end{tabular}

As farinhas extrusadas apresentaram considerável variação no GG, apresentando valores de 82,0 a 99,7\%. Entretanto, o modelo de regressão adotado não foi significativo $(\mathrm{p}>0,10)$ para este parâmetro. $\mathrm{O}$ coeficiente de correlação múltipla $\left(\mathrm{R}^{2}\right)$ foi de $62,7 \%$, indicando falta de ajuste do modelo aos dados.

Chiang \& Johnson (1977) verificaram o efeito da umidade, da temperatura e da velocidade do parafuso e de suas interações na extrusão de farinha de trigo. Segundo os autores, a gelatinização do amido aumentou de modo proporcional à elevação da temperatura (de 65 a $110^{\circ} \mathrm{C}$ ), tanto em umidade alta (24 ou $27 \%$ ) como baixa (18 ou 21\%). A gelatinização do amido diminuiu levemente com a elevação da umidade em temperaturas baixas. Com o aumento da rotação do parafuso (de 60 para $140 \mathrm{rpm}$ ), ocorreu a redução do GG. Segundo os autores, o aumento da velocidade do parafuso diminuiu o tempo de retenção da amostra no extrusor, que resultou na redução do GG. 
Iwe e Ngoddy (1998) observaram que em baixos teores de umidade (18\%) os valores de GG de farinha de batata-doce extrusada foram mais elevados.

$\mathrm{Na}$ extrusão de cereais Ibanoglu et al. (1996) verificaram que a gelatinização do amido aumentou com o incremento da temperatura de processo, de 60 para $120^{\circ} \mathrm{C}$. Segundo estes autores, com o aumento da temperatura do extrusor, as ligações de hidrogênio são intensivamente rompidas, de modo que mais amilose poderia ser solubilizada no meio, aumentando o grau de gelatinização. Neste trabalho, o aumento da velocidade do parafuso também aumentou o GG, provavelmente devido à intensificação do efeito da mistura e cisalhamento. Como no caso da temperatura, as ligações de hidrogênio poderiam ser enfraquecidas pela ação mecânica do parafuso. 


\section{CONSIDERAÇÕES FINAIS}

O índice de expansão dos extrusados mostrou variação significativa com a umidade da mistura e temperatura de extrusão. Os maiores valores de IE foram obtidos com altas temperaturas e baixas umidades e os menores valores ocorreram para baixas umidades e temperaturas e também elevadas umidades e temperaturas.

O modelo de regressão adotado para a dureza dos extrusados não foi significativo para os parâmetros estudados.

Quanto a cor, o componente $\mathrm{L}^{*}$ aumentou e o valor a* tendeu ao negativo com o aumento da umidade da farinha de batata-doce até aproximadamente 20-21\%. O componente $b^{*}$ e a DCO aumentaram com a diminuição da umidade.

A variação do índice de absorção de água, índice de solubilidade em água e tendência a retrogradação para as farinhas extrusadas não apresentou modelo de regressão de significância estatística dentro dos níveis das variáveis independentes.

A viscosidade a frio, o pico de viscosidade e a quebra de viscosidade das farinhas extrusadas diminuíram com a elevação da umidade até $20-21 \%$ e acima disto, mostraram aumento. Já a viscosidade final das farinhas extrusadas foi inversamente proporcional à rotação da rosca.

O grau de gelatinização se mostrou elevado para todas as farinhas extrusadas, entretanto, não apresentou modelo ajustado de variação com os parâmetros estudados. 


\section{CONCLUSÕES}

A extrusão é um processo que pode ser aplicado à farinha de batata-doce. Os extrusados sob a forma de snacks e farinhas pré-gelatinizadas apresentaram características físicas, físico-químicas e funcionais variáveis conforme o tratamento (combinação dos parâmetros) de extrusão.

Dentre os parâmetros de processo avaliados (umidade da mistura, temperatura na terceira zona e rotação da rosca) a umidade da mistura foi o que exerceu efeito mais pronunciado sobre as características dos produtos obtidos.

Alguns tratamentos geraram extrusados com bons índices de expansão e baixos valores de dureza, que são considerados requisitos de qualidade neste tipo de produto. As farinhas pré-gelatinizadas apresentaram elevados graus de gelatinização, com alguns tratamentos mostrando valores de viscosidade inicial e índices de absorção de água mais elevados. Estas farinhas podem ser incorporadas na formulação de sopas instantâneas, alimentos infantis e outros alimentos. 


\section{REFERÊNCIAS BIBLIOGRÁFICAS}

ALVES, R.M.L.; GROSSMANN, M.V.E. Parâmetros de extrusão para produção de “snacks" de farinha de cará (Dioscorea alata). Ciência e Tecnologia de Alimentos, v.22, n.1, p32-38, jan./abr. 2002.

AMANTE, E. R. Caracterização de amidos de variedades de mandioca (Manihot esculenta, Crantz) e de batata-doce (Ipomoea batatas). Viçosa, $1986.109 \mathrm{p}$. Dissertação (Mestrado) - Universidade Federal de Visçosa.

ANDERSON R. A.; CONWAY, V.F.P.; GRIFFIN, E.L. Gelatinization of corn grits by roll- and extrusion-cooking. Cereal Science Today, v.14, n.1, p.4-7, jan. 1969.

ARÊAS, J. A. G. Interações moleculares do amido durante o processo de extrusão. Boletim da Sociedade Brasileira de Ciência e Tecnologia de Alimentos, v.30, n.1, p.28-30, 1996.

ASCHERI, J. L. R. Efeito das variáveis de Extrusão nas características físicas e químicas de produtos intermediários (half-products). Campinas, 1994. Tese (Doutorado) Faculdade de Engenharia de Alimentos, Universidade Estadual de Campinas.

ASP, N. G., JOHANSSON, C. G., HALLMER, H., SILJESTRÖM, M. Enzymatic assay of insoluble and soluble dietary fiber. Journal of Agriculture and Food Chemistry, v.31, n.3, p.476-482, 1983. 
ASSOCIATION OF OFFICIAL ANALYTICAL CHEMISTS (AOAC). Official methods of analysis of the Association of Official Analytical Chemists. $16 \mathrm{ed}$. Arlington, 1995. 2v.

ATTENBURROW, G.E.; DAVIES, A.P.; GOODBAND, R.M.; INGMAN, S.J. The feature behaviour of starch and gluten in the glassy state. Journal Cereal Science Today, v.16, p.1-12, 1993.

BADRIE, N.; MELLOWES, W.A. Effect of extrusion variables on cassava extrudates. Journal Food Science, v.56, p.1334-1337, 1991.

BARRERA, P. Batata-doce: uma das doze mais importantes culturas do mundo. São Paulo: Ícone, 1986. 93p.

BARUFFALDI, R.; OLIVEIRA, M. N. Fundamento de tecnologia de alimentos. São Paulo: Atheneu, 1998. v.3, 317p. (Série: Ciência, Tecnologia, Engenharia de Alimentos e Nutrição).

BHATTACHARYA, S.; SUDHA, M. L.; RAHIM, A. Pasting characteristics of an extruded blend of potato and wheat flours. Journal of Food Engineering, v.40, p.107-111, 1999.

BIBLE, B.B.; SINGHA, S. Canopy position influences CIELAB coordinates of peach color. HortScience, v.28, n.10, p.992-993, 1993.

BOX, G.E.P.; BEHEKEN, D.W. Somenew three level designs for the study of quantitative variables. Technometrics, v.2, n.4, p.455-475, 1960. 
BOX, G.E.P.; HUNTER, W.G.; HUNTER, J.S. Statistics for experimenters: an introduction to design, data analysis, and model building. New York: John Wiley and Sons, 1978.

CARVALHO, R. V.; ASCHERI, J. L. R.; CAL-VIDAL, J. Efeito dos parâmetros de extrusão nas propriedades físicas de extrusados $(3 \mathrm{G})$ de misturas de farinhas de trigo, arroz e banana. Ciência e Agrotecnologia, v.26, n.5, p.1006-1018, set./out. 2002.

CHANG, Y.K.; HASHIMOTO, J.M.; ACIOLI-MOURA, R.; MARTÍNEZ-FLORES, H. E.; MARTÍNEZ-BUSTOS, F. Influence of extrusion condition on cassava starch and soybean protein concentrate blends. Acta Alimentaria, v.30, n.2, p.189-203, 2001.

CHANG, Y.K.; EL-DASH, A.A. Effects of acid concentration and extrusion variables on some physicl characteristics and energy requirements of cassava starch. Brazilian Journal of Chemical Engineering, v.20, n.2, p.129-137, abr./jun. 2003.

CHIANG, B. Y.; JOHNSON, J. A. Gelatinization of starch in extrused products. Cereal Chemistry, v.54, n.3, p.436-443, May/Jun. 1977.

COLLADO, L.S., MABESA, R.C., CORKE, H. Genetic variation in the physical properties of sweet potato starch. Journal of Agriculture and Food Chemistry, v.47, p.4195-4201, 1999.

COLONNA, P.; DOUBLIER, J.L.; MELCION, J.P., MONREDON, F.; MERCIER, C. Extrusion cooking and drum drying of wheat starch. I. Physical and macromolecular modifications. Cereal Chemistry, v.61, n.6, p.538-543, 1984. 
COLONNA, P.; BULEON, A.; MERCIER, C. Physically modified starch. In: GALLIARD, T. Starch: proprerties and potencial. Chischester: John Wiley \& Sons, 1987. cap.4, p.79-114.

DELla VAlle, G.; VERGES, B.; COLONNA, P., PATRIA, A. Relations between rheological properties of molten starches and their expansion behaviour in extrusion. Journal of Food Engineering, v.31, p.277-296, 1997.

DING, Q.; AINSWORTH, P.; TUCKER, G.; MARSON, H. The effect of extrusion conditions on the physicochemical properties and sensory characteristics of ricebased expanded snacks. Journal of Food Engineering, v.66, p.283-289, 2005.

EL-DASH, A.A. Aplication and control of thermoplastic extrusion of cereals for food and industrial uses. In: POMERANZ, Y.; MUNCH, L. Cereals a renewable resource: theory and pratice. St. Paul: AACC, 1982. cap.10, p.165-216.

EL-DASH, A.; GONZALES, R.; CIOL, M. Response surface methodology in the control of thermoplastic extrusion of starch. Journal of Food Engineering, v.2, n.2, p.129-152, 1983.

FAUBION, J.M.; HOSENEY, R.C. High temperature and short time. Extrusion-cooking of wheat starch and flour. I- Effect of moisture and flour type on extrudate properties. Cereal Chemistry, v.59, n.6, p. 529-533, 1982.

FELLOWS, P. Extrusion. In: FELLOWS, P. Food processing technology: principles and practive. Cambridge: Woodhead Publishing, 2002. cap.14, p.294-308.

FIGUEIRA, F. A. R. Novo manual de olericultura: agrotecnologia moderna na produção e comercialização de hortaliças. Viscosa: UFV, 2000. 402 p. 
FOOD AND AGRICULTURE ORGANIZATION OF UNITED NATIONS. FAO Production Yearbook. Rome, 1997.

FRANCO, C.M.L.; DAIUTO, E.R.; DEMIATE, I.M.; CARVALHO, L.J.C.B.; LEONEL, M; CEREDA, M.P.; VILPOUX, O.F.; SARMENTO, S.B.S. Propriedades gerais do amido. São Paulo: Fundação Cargil, 2001. v.1, 224p. (Cultura de Tuberosas Amiláceas Latino Americanas).

GALLANT, D.J.; BEWA, H.; BUY, Q.H.; BOUCHET, B.; SZYLIT, O.; SEALY, L. On ultrastructural and nutrional aspects of some tropical tuber starches. Starch/Stärke, v.34, n.8, p.255-262, 1982.

GALLIARD, T.; Starch availability e utilization. In: GALLIARD, T. Starch: proprerties and potencial. Chischester: John Wiley \& Sons, 1987. cap.1, p.1-15.

GALLIARD, T.; BOWLER, P. Morphology and composition of starch. In: GALLIARD, T. Starch: proprerties and potencial. Chischester: John Wiley \& Sons, 1987. cap.3, p.55-78.

GAINES, C.S.; KASSUBA, A.; FINNEY, P.L. Instrumental measurement of cookie hardness. I. Assessment of methods. Cereal Chemistry, v. 69, n.2, p.115-119, 1992.

GIBSON, G. R.; WILLIAMS, C. M. Functional foods: concept to product. Cambridge: Woodhead Publishing, 2000. 374p.

GOMEZ, M. H.; AGUILERA, J. M. Changes in the starch fraction during extrusioncooking of corn. Journal of Food Science, v.48, p.378-381, 1983. 
GUHA, M.; ALI, S.Z.; BHATTACHARYA, S. Twin-screw extrusion of rice flour without a die: effect of barrel temperature and screw speed on extrusion and extrudate characteristics. Journal of Food Engineering, v.32, p.251-267, 1997.

GUHA, M.; ALI, S.Z.; BHATTACHARYA, S. Effect of barrel temperature and screw speed on rapid viscoanalyser pasting behavior of rice extrudate. International Journal of Food Science and Technology, v.33, p.259-266, 1998.

GUTKOSKI, L.C.; EL-DASH, A.A. Effect of extrusion process variables on physical and chemical properties of extruded oat porducts. Plant Foods for Human Nutrition, v.54, p.315-325, 1999.

GUTKOSKI, L.C. Extrusão de produtos de aveia. In: GUTKOSKI, L.C.; PEDÓ, I. Aveia: composição química, valor nutricional e processamento. São Paulo: Varela, 2000. cap.7, p.169-103.

HARMANN, D.V.; HARPER, J.M. Effect of extruder geometry on torque and flow. American Society of Agricultural Engineering, v.16, p.1175-1178, 1973.

HARPER, J.M. Extrusion processing of food. Food Technology, v.32, n.7, p.67-72, Jul. 1978 .

HARPER, J.M. Extrusion of foods. Boca Raton: CRC Press, 1981. v.1, 212 p.

HARPER, J.M. Extrusion and texturization of foods. Food Technology, v.40, n.3, p.70$76,1986$.

HASHIMOTO, J. M.; GROSSMAN, M. V. E. Effects of extrusion conditions on quality of cassava bran/cassava starch extrudates. International Journal of Food Science and Technology, v.38, n.5, p.511-517, 2003. 
IBANOGLU, S.; AINSWORTH, P.; HAYES G.D. Extrusion of tarhana: effect of operating variables on starch gelatinization. Food Chemistry, v.57, n.4, p.541-544, 1996.

INSTITUTO ADOLFO LUTZ. Normas analíticas do Instituto Adolfo Lutz: métodos químicos e físicos para análise de alimentos. 3 ed. São Paulo, 1985. v.1.

INTERNATIONAL ORGANIZATION FOR STANDARDIZATION. Norme internationale: riz détermination de la teneur en amylose. Suisse, 1987. 5p. (ISO 6647)

IWE, M. O. Effects of extrusion cooking on functional properties of mixtures of full fast soy and sweet potato. Plant Foods for Human Nutrition, v.53, p.37-46, 1998.

IWE, M. O.; NGODDY, P. O. Proximate composition and some functional properties of extrusion cooked soybean and sweet potato blends. Plant Foods for Human Nutrition, v.53, p.121-132, 1998.

IWE, M.O.; WOLTERS, I.; GORT, G.; STOLP, W.; VAN-ZUILICHEM, D.J. Behaviour of gelatinisation and viscosity in soy-sweet potato mixtures by single screw extrusion: a response surface analysis. Journal of Food Engineering, v.38, p.369-379, 1998.

IWE, M. O., VAN ZUILICHEM, D. J., NGODDY, P. O., LAMMERS, W. Amino acid and protein dispersibility index (PDI) of mixtures of extruded soy and sweet potato flours. Lebensmittel-Wissenschaft Und Technologie, v.34, n.2, p.71-75, 2001. 
IWE, M.O.; VAN-ZUILICHEM, D.J.; STOLP, W.; NGODDY, P. Effect of extrusion cooking of soy-sweet potato mixtures on available lysine content and browning index of extrudates. Journal of Food Engeineering, v.62, p.143-150, 2004.

KOHYAMA, K., NISHINARI, K. Cellulose derivatives effects on gelatinization and retrogadation of sweet potato starch. Journal of Food Science, v.57, n.1, p.128-131, 1992.

LI, J.-Y..; YEH, A.-I Relationships between thermal, rheological characteristics and swelling power for various starches. Journal of Food Engineering, v.50, p.141$148,2001$.

LINKO, Y.Y.; VUORINEN, H.; OLKKU, J.; LINKO, P. The effect of HTST on retention of cereal alfa-amylase activity and on enzymatic hydrolysis of barley starch. In: LINKO, P.; LARINKARI, J. Food Processing Engineering. London: Elsevier Applid Science, 1980. v. 2, p.210-223.

MERCIER, C.; FEILLET, P. Modification of carbohydrate components by extrusioncooking of cereal products. Cereal Chemistry, v.52, n.3, p.283-297, may/jun. 1975.

MILLER, G. L. Use of dinitrosalicilic acid reagent for determination of reducing sugar. Analytical Chemistry, v.31, n.3, p.426-431, Mar. 1959.

MIRANDA, J.E.C.; FRANÇA, F.H.; CARRIJO, O.A.; SOUZA, A.F.; PEREIRA, W.; LOPES, C.A.; SILVA, J.B. A cultura da batata doce. Brasília: EMBRAPA, 1995. $94 \mathrm{p}$.

NEWPORT SCIENTIFIC. Operation manual for series 4: instructions manual. Warriedwood, 1998. 123p. 
NODA, T.; TAKAHATA, Y.; SATO, T.; IKOMA, H.; MOCHIDA, H. Combined effects of planting and harvesting dates on starch properties of sweet potato roots. Carbohydrate Polymers, v.33, p.169-176, 1997.

ONWUlatA, C. I.; SMITH, P. W.; KOnStAnCE, R. P.; HOLSINGER, V. H. Incorporation of whey products in extruded corn, potato or rice snacks. Food Research International, v.34, p.679-687, 2001.

RICKARD, J. E., BEHN, K. R. Evaluation of acid and enzyme hidrolytic methods for the determination of cassava starch. Journal of Science of Food and Agriculture, v.41, n.4, p.373-379, 1987.

SAS INSTITUTE. Inc. The SAS System release 8.2. SAS Institue Inc, Carry: NC, 1999.

SEBIO, L. Efeito de alguns Parâmetros Operacionais de Extrusão nas Propriedades Físico-químicas da farinha de inhame (Dioscorea rotundata). Campinas, 1996. 106p. Dissertação (Mestrado) - Faculdade de Engenharia de Alimentos, Universidade Estadual de Campinas.

SILVA, J. B. C., LOPES, C. A., MAGALHÃES, J. S. Cultura da batata-doce. In: CEREDA, M. P. (coord). Agricultura: tuberosas amiláceas latino americano. São Paulo: Fundação Cargil, 2002. v.2, cap.22, p.448-504. (Cultura de Tuberosas Amiláceas Latino Americanas).

SOMOGY, M. Determination of blood sugar. Journal Biology Chemistry, n.160, p.69-73, 1945.

SOUZA, R. C. R.; ANDRADE, C. T. Investigação dos processos de gelatinização e extrusão de amido de milho. Polímeros: Ciência e Tecnologia, v.10, n.1, p.24-30, 2000. 
STANLEY, D.W. Chemical and structural determinants of texture of fabricated foods. Food Technology, v.40, n.3, p.65-68, 1986.

THOMAS, D. J.; ATWELL, W. A. Starches. Saint Paul: Zagan Press, 1997. 93 p. (Zagan Press Handbook Series).

THYMI, S.; KROKIDA, M.K.; PAPPA, A.; MAROULIS, Z.B. Structural properties of extruded corn starch. Journal of Food Engineering, v.68, p.519-526, Jun. 2005.

VAN DEN EINDE, R.M.; AKKERMANS, C.; VAN DER GOOT, A.J.; BOOM, R.M. Molecular breakdown of corn starch by thermal and mechanical effects. Carbohydrate Polymers, v.56, p.415-422, 2004.

VILLAREAL, R. L. Sweet potato: its present and potencial role in the food production of developing countries. South Pacific Commission Tech Paper, v.174, p.170-182, 1977.

WHALEN, P.J.; BASON, M.L.; BOOTH, R.I.; WALKER, C.E.; WILLIAMS, P.J. Measurement of extrusion effects by viscosity profile using the rapid viscoanalyser. Cereal Foods World, v.42, n.6, p.469-475, jun. 1997.

YACU, W. Process instrumentation and control in food extruders. Cereal Foods World, n.35, n.9, p.919-926, 1990. 